\title{
Seasonal Thermal Energy Storage
}

\section{May 1984}

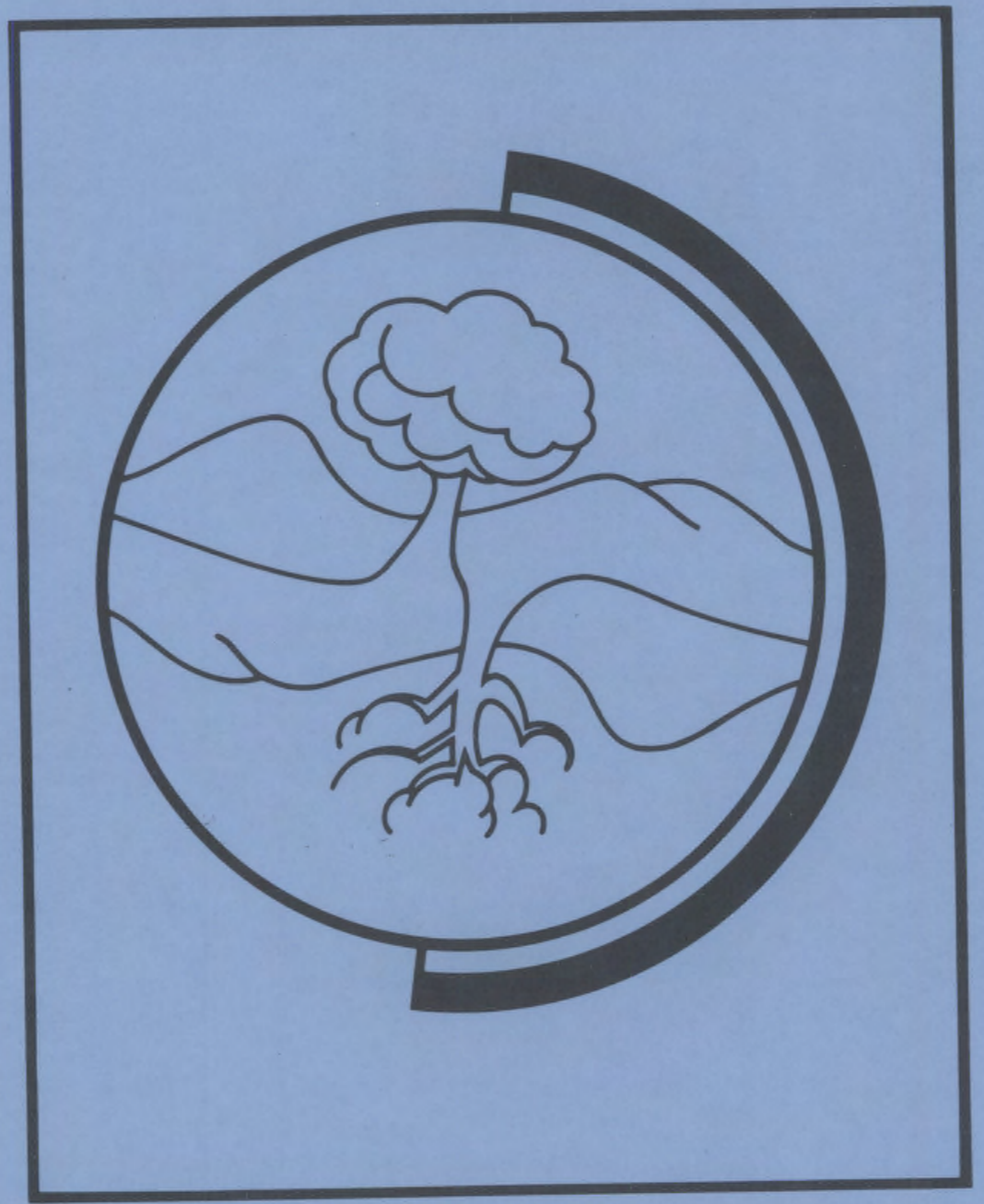

Prepared for the U.S. Department of Energy under Contract DE-AC06-76RLO 1830

Pacific Northwest Laboratory Operated for the U.S. Department of Energy by Battelle Memorial Institute 


\section{DISCLAIMER}

This report was prepared as an account of work sponsored by an agency of the United States Government. Neither the United States Government nor any agency thereof, nor any of their employees, makes any warranty, express or implied, or assumes any legal liability or responsibility for the accuracy, completeness, or usefulness of any information, apparatus, product, or process disclosed, or represents that its use would not infringe privately owned rights. Reference herein to any specific commercial product, process, or service by trade name, trademark, manufacturer, or otherwise, does not necessarily constitute or imply its endorsement, recommendation, or favoring by the United States Government or any agency thereof. The views and opinions of Stathors expressed herein do not necessarily state or reflect those of the United States Government or any agency thereof.

\section{PACIFIC NORTHWEST LABORATORY operated by \\ BATTELLE \\ for the \\ UNITED STATES DEPARTMENT OF ENERGY under Contract DE-AC06-76RLO 1830}

\begin{tabular}{|c|c|}
\hline \multicolumn{2}{|c|}{$\begin{array}{c}\text { National Technical Information Service } \\
\text { United States Department of Commerce } \\
5285 \text { Port Royal Road } \\
\text { Springfield, Virginia } 22161\end{array}$} \\
\hline \multicolumn{2}{|c|}{$\begin{array}{l}\text { NTIS Price Codes } \\
\text { Microfiche } A 01\end{array}$} \\
\hline \multicolumn{2}{|c|}{ Printed Copy } \\
\hline Pages & $\begin{array}{l}\text { Price } \\
\text { Codes }\end{array}$ \\
\hline $001-025$ & $\mathrm{~A} 02$ \\
\hline $026-050$ & $\mathrm{~A} 03$ \\
\hline $051-075$ & $\mathrm{AO4}$ \\
\hline $076-100$ & A05 \\
\hline $101-125$ & A06 \\
\hline $126-150$ & A07 \\
\hline $151-175$ & A08 \\
\hline $176-200$ & $A 09$ \\
\hline $201-225$ & $\mathrm{~A} 010$ \\
\hline $226-250$ & A011 \\
\hline $251-275$ & $\mathrm{~A} 012$ \\
\hline $276-300$ & $\mathrm{~A} 013$ \\
\hline
\end{tabular}



R. D. Alten
L. D. Kannberg
J. R. Raymond

May 1984

Prepared for the U.S. Department of Energy under Contract DE-AC06-76RLO 1830

Pacific Northwest Laboratory

Richland, lashington 99352 



\section{FOREWORD}

Seasonal thermal energy storage (STES) involves storing thermal energy, such as winter chill, summer heat, and industrial waste heat, for future use in heating and cooling buildings or for industrial processes. Widespread development and implementation of STES would significantly reduce the need to generate primary energy in the U.S. In fact, 1980 data indicate that STES is suitable for providing 5 to $10 \%$ of the nation's energy with major contributions in the commercial, industrial, and residential sectors.

Aquifer thermal energy storage (ATES) is predicted to be the most cost-effective technology for seasonal storage of low-grade thermal energy. Approximately $60 \%$ of the U.S. is underlain with aquifers potentially suitable for underground energy storage. Under sponsorship of the U.S. Department of Energy, Pacific Northwest Laboratory (operated by Battelle Memorial Institute) has managed numerical modeling, laboratory studies, evaluation of environmental and institutional issues, and fieid testing of ATES at several sites.

This report presents a descriptive summary of research and development in seasonal thennal energy storage technology up to August 1983. It encompasses U.S. efforts sponsored by the U.S. Department of Energy, as we11 as studies performed in and by other nations. Research into aquifer therma? energy storage is disclissed in some depth. Studies of other STES configurations are also described. An economic assessment of the various STES systems is presented. The report was originally prepared as a chapter in a book on energy storage being prepared under the auspices of Oak Ridge National Laboratory.

It is hoped that this document will serve as an interesting introduction to STES for those unfamiliar with the concept.

Landis D. Kannberg, Manager Underground Energy Storage Program 
. 


\section{SUMMARY}

Seasonal thermal energy storage (STES) involves the technology of economically storing sensible heat or cold from cogeneration, by-product, or natural sources during periods of energy surplus to partially or wholly satisfy later demands. These potential sources include heat from combustion, nuclear, and solar plants and cold from the atmosphere. Utilization could reduce electricity generation peaks by supplying heat sources and sinks for district heating and cooling systems. Initial investigations in the U.S. have used formations saturated with ground water (aquifers) to store water at both elevated and depressed temperatures. Later studies focussed on nonaquifer reservoirs for sensible thermal storage and sensible/latent chill storage; these alternatives include pond, lake, cavern, tank, earth, rock boreholes, and ice.

There is considerable study of STES technology in northern Europe and Scandinavia. Many of these foreign STES studies involve design and construction of pilot or full-scale systems. Frequently, the foreign studies include integration with distinct heating and cooling as well as solar heat storage.

In the United States, the STES Program sponsored by the U.S. Department of Energy has comprised literature review, numerical modeing, geochemical experimentation, and field testing. Aquifer response has been measured at Mobile, Alabama, and Stony Brook, New York. A high temperature injection/retrieval facility is active at St. Paul, Minnesota. The program has investigated recovery efficiencies, hydraulic behaviors, geochemical reactions, heat transfer, reliability, and economic characteristics.

In both the United States and abroad, aquifers have also been studied specifically with respect to basic geologic requirements, regional availability, potential sources of system degradation and offsetting beneficiating methods, and environmental/institutional influences. 
Each STES technology option probably has applicability under a particular set of socioeconomic and geographic circumstances. Warm-water storage in aquifers and ice storage in manufactured facilities appear likely to supply district temperature-conditioning systems in the near term, especially if petroleum and natural gas prices resume escalation. 


\section{CONTENTS}

FOREWORD. .......................

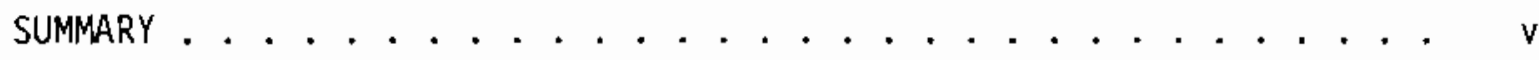

FIGURES ............................. xi

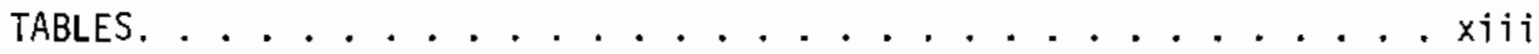

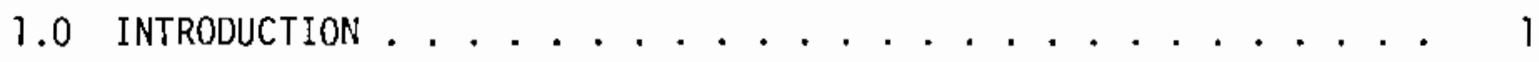

2.0 DEPARTMENT OF ENERGY SEASONAL THERMAL ENERGY STORAgE PROGRAM . . 3

3.0 AQUIFER THERMAL ENERGY STORAGE TECHNOLOGY . . . . . . . 7

3.1 SYSTEM DESIGN AND OPERATION . . . . . . . . . . 7

3.1.1 General Concept ............ 7

3.1 .2 Sources of Heat and Chill ......... 9

3.1.3 Potential Markets. ............. . 10

3.2 AQUIFER CHARACTERISTICS ................... 11

3.2.1 Geohydrology ............... 11

3.2 .2 Petrology.................... 11

3.2.3 Regional 0ccurrence ............ . . 12

3.2.4 Environmental Assessment . . . . . . . . . 12

3.3 ENERGY INJECTION, STORAGE AND RECOVERY . . . . . . . 14

3.3.1 Energy Losses . . . . . . . . . . . . 15

3.3.2 System Impairment Mechanisms . . . . . . . 15

3.3.3 Beneficiation Procedures .......... . . 17

3.4 DOMESTIC FIELD STUdIES . . . . . . . . . . 17

3.4.1 Mobile, Alabama, Field Test Facility....... 18

3.4.2 St. Paul, Minnesota, Field Test Facility. . . . . 23

3.4.3 Stony Brook, New York, Demonstration Project. . . . 30

3.4.4 Tusca7oosa, Alabama, Field Experiment. . . . . . 36 
3.5 LABORATORY STUDIES . . . . . . . . . . . . . 38

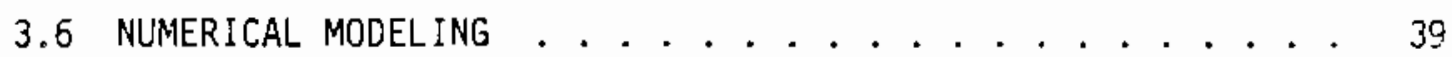

3.7 APPLICABILITY. . . . . . . . . . . . . . 44

3.8 COMPARISON WITH OTHER STORAGE TECHNOLOGIES . . . . . . . 46

4.0 Alternative Stes TeChnOLOGY . . . . . . . . . . . 47

4.1 DESCRIPTION OF ALTERNATIVE CONCEPTS . . . . . . . 47

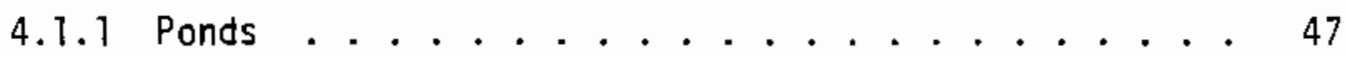

4.1 .2 Lakes ................ . . . 49

4.1 .3 Caverns .............. . . 50

4.1 .4 Tankage ............... 53

4.1 .5 Earth ............... 55

4.1 .6 Rock ............... . . 57

4.1 .7 Ice ...................... 58

4.1 .8 Hybrid............... . . 59

4.2 TECHNOLOGY ASSESSMENT . . . . . . . . . . . 60

4.2 .1 Storage Sizing ............ 60

4.2.2 Capital Cost .............. . 62

4.2.3 Thermal Effectiveness .......... . 64

4.2.4 Advantages and Disadvantages . . . . . . . . . 65

4.3 CONCLUSIONS . . . . . . . . . . . . . . . . 67

5.0 FOREIGN STUdIES IN SEASONAL THERMAL ENERGY STORAGE . . . . . 69

5.1 SWEDEN ............................. 69

5.2 FEDERAL REPUBLIC OF GERMANY . . . . . . . . . . 71

5.2.1 Artificial Storage Lake ........... 71

5.2.2 Artificial Aquifer Storage . . . . . . . . 73

5.2.3 Thermochemical Storage........... . 74

5.3 PEOPLES REPUBLIC OF CHINA ............. 75 
5.4 THE NeTHERLANDS . . . . . . . . . . . . . . 77

5.5 CANADA. . . . . . . . . . . . . . . 79

5.6 DENMARK . . . . . . . . . . . . . . . . 80

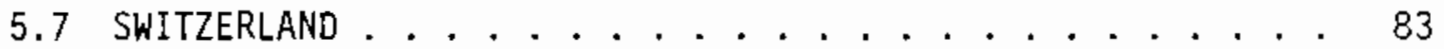

5.8 fRANCE ....................... . . 84

6.0 ECONOMIC ASSESSMENT . . . . . . . . . . . . . . . . . . 87

6.1 AQUIFER STORAGE OF HEATED WATER . . . . . . . . . . . 87

6.2 AQUIFER STORAGE OF CHILLED WATER . . . . . . . . . . . 91 9

6.2.1 Estimated Costs of ATES with a Seasonal

Chill Source................ . 91

6.2.2 Aquifer Storage of Chilled

water at Stony Brook, New York . . . . . . . . . . 94

6.3 ALTERNATIVE STORAGE CONCEPTS FOR CHILLED WATER . . . . . . 95

7.0 GENERAL CONCLUSIONS . . . . . . . . . . . . . . . . 101

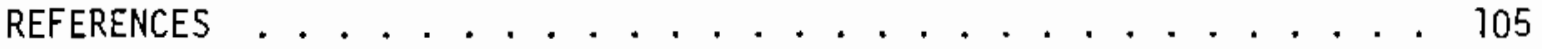





\section{FIGURES}

1. Aquifer Thermal Energy Storage . . . . . . . . . . . 8

2. Major Aquifer Areas of the United States .......... 13

3. Schematic of Second Aquifer Experiment at Auburn University .................. 20

4. Conceptual Well Doublet System Installed in Confined Aquifer . . 20

5. Temperature Distribution after the Second Cycle Storage Period, Mobile FTF . . . . . . . . . . . . 21

6. Summary of Lithologies and Hydrologic Zones of the FranconiaIronton-Galesville Aquifer and Confining Bed, St. Paul Field Test Facility. . . . . . . . . . . . . . . . 24

7. St. Paul FTF Well Field Configuration. . . . . . . . . 25

8. Location of Stony Brook Project. . . . . . . . . . . . . 31

9. Generalized Hydrologic Cross Section of Long Island. . . . . . 32

10. 1981 Mobile Experiment First Cycle Production Temperature as a Function of Time . . . . . . . . . . . . . 41

11. Injection Scenarios Modeled ............. 42

12. Pond Seasonal Thermal Energy Storage . . . . . . . . . . 48

13. Lake Seasonal Thermal Energy Storage . . . . . . . . . . 49

14. Cavern Seasonal Thermal Energy Storage . . . . . . . . . 50

15. Water Temperatures in the Pioneer $A$ and Zenith \#3 Shafts with Geometry of the Shafts and Drift Levels Shown Schematically. . . 52

16. Insulated Tank Seasonal Thermal Energy Storage . . . . . . . 54

17. Earth Seasonal Thermal Energy Storage . . . . . . . . . . 56

18. Rock Well Seasonal Thermal Energy Storage . . . . . . . . 57

19. Ice Seasonal Therma\} Energy Storage . . . . . . . . . 58

20. Hybrid Solar/Conventional Pond for Seasonal Thermal Energy Storage. . . . . . . . . . . . . . . 60 
21. Home Equivalent Capacity Required .............. . 61

22. Approximate Capital Cost (Single Inventory Turnover) . . . . 62

23. Approximate Costs Versus Inventory Turnover (Storage Only) . . 63

24. Cost of ATES Versus Conventional Technology . . . . . . . . . 89

25. ATES Component Cost Breakdowns . . . . . . . . . . . 9 90 


\section{$\underline{\text { TABLES }}$}

1. Physical, Chemical and Biological Processes

That Can Impact Aquifer Thermal Energy Storage . . . . . . . 16

2. Beneficiation Techniques for Countering Major Physical, Chemical and Biological Processes Associated with Well Operations .... 18

3. Key Parameters for the Short-Term Test Cycles at the University of Minnesota ATES Field Test Facility. . . . . . . . . . 30

4. Nonaquifer STES Concept Technology Assessment . . . . . . . 61

5. Heat Recovery Potential and Quality ............ 64

6. Nonaquifer STES Concept Main Advantages and 0isadvantages ... 65

7. Capital Cost of Ice Storage and Conventional Air Conditioning Systems. . . . . . . . . . . . . 97

8. Annual Operating and Maintenance Costs .......... 98

9. Economic Parameters for Present Worth Analysis . . . . . . . 98

10. Present Worth of Ice Storage and Conventional Air Conditioning systems. . . . . . . . . . . . . . . gg 



\subsection{INTROOUCTION}

The basic function of an energy storage system is to accept, store, and discharge energy in accordance with availability and demand. Thus, a thermal energy storage system provides a buffer between time-dependent energy inputs and thermal and/or electrical power loads. Energy may be supplied to storage as water heated by a working fluid from a solar collection system, by an industrial or utility waste heat source, or by a cogeneration power plant. Conversely, chilled water or ice may be stored for future use in air conditioning.

Seasonal thermal energy storage (STES) using heat or cold available from surplus, waste, climatic, or cogeneration sources shows great promise to reduce peak demand, reduce electric utility load problems, and contribute to establishing favorable economics for district heating and cooling systems. The numerous motivations for storing large quantities of thermal energy on a long-term basis include 1) the need to store solar heat that is collected in the summer for use in the winter months, 2) the cost-effectiveness of using heat now wasted in electrical generation plants, 3) the need to profitably use industrial waste heat, and 4) the need to more economically provide summer cooling for buildings (Raymond 1980). Aquifers, ponds, lakes, quarries, caverns, mines, rock and earth, and engineered structures have potential for seasonal storage.

Storage in aquifers appears to be one of the most economical and widely applicable STES techniques (Meyer and Hausz 1980). Most geologists and groundwater hydrologists agree that heated and chilled water can be injected, stored, and recovered from aquifers. Geologic materials are good thermal insulators, and potentially suitable aquifers are distributed throughout the United States. Many potential energy sources exist for use in an aquifer thermal energy storage system. These inciude solar heat, power plant cogeneration, winter chill, and industrial waste heat sources, 
such as aluminum plants, paper and pulp mills, food processing plants, garbage incineration units, cement plants, and iron and steel mills. Energy sources ranging from $50^{\circ} \mathrm{C}$ to higher than $250^{\circ} \mathrm{C}$ are available for heating. Potential energy uses include individuai- or district-scale space heating, industrial or institutional plant heating, and processing or manufacturing heating. Recent studies and small-scale field experiments have reported energy recovery rates of more than $70 \%$ for seasonal storage.

Other STES methods also appear feasible. Ice generation or harvesting followed by seasonal storage may augment or replace substantial portions of building space air conditioning, which accounts for the summer electrical peak demand for many utilities. Alternatives for therma? storage, such as lakes, ponds, and moist or dry earth, are also potential means for exploiting the seasonal characteristics of energy availability and requirements. These methods are probable candidates where siting conditions are favorable. It has been estimated that STES could reduce peak national demands for energy by as much as $7.5 \%$ if pursued aggressive1y.

This report describes the following: 1) the U.S. Department of Energy Seasona1 Thermal Energy Storage Program, 2) aquifer thermal energy storage technology, 3) al ternative STES technology, 4) foreign studies in seasonal thermal energy storage, and 5) economic assessment. The available subject material is rapidiy expanding. This summary does not attempt to include all significant projects. 


\subsection{DEPARTMENT OF ENERGY SEASONAL THERMAL ENERGY STORAGE PROGRAM}

The concept of seasonal thermal energy storage (STES) as a conservation measure was incorporated into the programs of the U.S. Energy Research and Development Agency (ERDA), Division of Energy Storage Systems (STOR) in 1975. This organization is now the U.S. Department of Energy (DOE), Office of Energy Systems Research (OESR). Seasonal thermal energy storage evolved within the Low-Temperature Thermal Energy Storage Program (LTTESP) managed by the DOE Dak Ridge National Laboratory (ORNL).

The objectives of the LTTESP were to carry out research and development on new technologies for storing thermal energy as low-temperature sensible and latent heat, and to develop, test, and demonstrate cost-effective systems for collecting, storing, and discharging thermal energy which will have significant national impact on energy conservation. Within LTTESP, the seasonal thermal energy storage work was in the Geological Storage Thrust Area. (a)

Aquifer thermal energy storage (ATES) was identified as having significant near-term national economic/conservation potential. As a result, major expansion of work in the Geological Storage Thrust area was planned for techno-economic studies, experimental field test, mathematical modeling, environmental/institutional analysis, and demonstration projects.

Auburn University, under ERDA/U.S. Geological Survey auspices, started an ATES research project in June 1975 at a test site near Mobile, Alabama. Initial work involved injection of heated water from a power plant discharge canal into a confined aquifer. Drilling of observation wells and the injection well was finished in the Fall of 1976, and heated water injection, storage and recovery were completed in 1977. Although some problems occurred with injection well plugging, the experiment served to demonstrate that ATES could be achieved, at least at lower injection temperatures, with reasonable recovery efficiencies.

\footnotetext{
(a) LTTESP was divided into three "Thrust Areas": Geological Storage, Phase Change Material Storage and Waste Energy Reuse.
} 
Adaptation of the CCC (for Conduction, Convection, Compaction) numerical hydrodynamic model for application to assessment of ATES waS started by Lawrence Berkeley Laboratory in 1977. In addition, a project was started in 1977 by Desert Reclamation Industries, Inc., to evaluate the feasibility of chill ATES storage at JFK International Airport, New York. Also initiated in 1977 was a chill ATES storage project by Texas A. \& M. University.

In 1978, STES research expanded to include a survey of ATES applicability by the Tennessee Valley Authority (TVA), an economic analysis of the proposed JFK Airport chill ATES project, environmental impact of ATES, and a study to locate an aquifer suitable for ATES near Bellingham, Washington. A conceptual design was started for incorporation of ATES for the proposed Twin Cities (Minnesota) District Heating Project. Work continued on refinement of numerical models for ATES assessment. A second experiment was completed at the Mobile ATES Test Site where water was pumped from an unconfined aquifer, heated to approximately $55^{\circ} \mathrm{C}$ in a boiler and injected in the confined storage aquifer, stored for a period of time and then recovered. Roughiy $65 \%$ of the injected energy was recovered at a cutoff temperature of $33^{\circ} \mathrm{C}$. The well plugging problem that occurred during the preliminary experiment was significantly reduced due to the relatively low level of suspended solids in the injection water. Periodic backwashing of the injection well contributed to injectivity improvement.

Management of the STES section of the Low-Temperature Thermal Energy Storage Program was assigned to the Pacific Northwest Laboratory (PNL) in Apri] 1979. The STES Program was reorganized into an ATES Demonstration Task and a parallei Technical Support Task. An RFP was issued under the ATES Demonstration Task, and proposals were received for preparation of a site-specific ATES demonstration project aquifer characterization and conceptional design. Under the Technical Support Task, work continued on ATES research at the Mobile, Alabama, Test Site, with successful completion of the second heat injection experiment; the CCC numerical model was calibrated using the heat injection/recovery test data set. The technical feasibility study of ATES in the TVA region was 
completed, with the conclusion that implementation of ATES systems would be technicaliy feasible in the study area, and that the major concern would be economic practicality. No further work was contemplated because of the adverse economic climate. Work on the ATES research project at Texas A. \& M. University was completed with finishing of the recovery phase of the chill injection test. The test was successful in that potential problems of iron precipitation were solved and injection and recovery proceeded smoothly. However, energy recovery efficiency was low (about 20\%) because of high groundwater velocities and precipitation infiltration. A suitable aquifer for ATES was not located in the Bellingham, Washington area during the limited test drilling, and work in this area was concluded. The preliminary ATES field investigation was completed at the JFK Airport. This investigation concluded that, al though the project would be technically feasible, the legal/institutional and economic barriers probably would preclude its near-term implementation.

Work continues on ATES environmental assessment. Investigations were initiated in areas of STES technology compilation/transfer, ATES geochemistry, legal/institutional constraints and economic assessment.

In response to proposals submitted, three Phase I ATES Demonstration Projects were initiated in 1980. These projects were sited at Bethel, Alaska (low temperature storage); State University of New York Stony Brook Campus (chill storage); and the St. Paul Campus, University of Minnesota (high temperature heat storage). Work continued on legal/institutional assessment, economic assessment, technology transfer, geochemical analysis and numerical modeling of ATES systems. A Programmatic Environmenta? Assessment Document was prepared for the ATES Demonstration Task. The Mobile, Alabama, Field Test Site was revised to a true doublet ATES system (with production and injection from the same aquifer). New injection and supply wells were drilled into the storage aquifer, and initial hydrologic tests were performed. Work was started to evaluate and assess nonaquifer (alternative) thermal energy storage technology.

Severe recisions in the STES Program budget were imposed in April 1981, and greater fund reductions were projected for fiscal year 1982 
(starting in October 1981). The budget reductions required termination of the Bethel, Alaska, and Stony Brook, New York, ATES Demonstration Projects. Plans were made to revise the St. Paul, Minnesota, High Temperature Demonstration Project to a High Temperature Field Test Facility. Work continued essentially on schedule at the Mobile, Alabama, Field Test Facility. Technology support tasks were continued in reduced scope and funding, with the exception of the technology transfer, legal/ institutional assessment and environmental assessment tasks which were terminated. Some follow-on work was planned at the Stony Brook site to resolve a well-plugging problem that occurred during chilled water reinjection. In October 1981, the STES Program was revised and incorporated with the Compressed Air Energy Storage (CAES) Program into the Underground Energy Storage (UES) Program at the Pacific Northwest Laboratory.

In 1982, revision of the St. Paul ATES Demonstration Project to a Field Test Facility was completed, and first injection of heated water occurred at the site. The CCC numerical model was verified against the second-cycle Mobile FTF data set and successfully used to simulate and predict the results of the third cycle heat injection test at the Mobile facility. Completion of the second and third cycle heat injection $\left(85^{\circ} \mathrm{C}\right)$ tests completes the planned work at the Mobile site. Additional emphasis was placed on nonaquifer methods of thermal energy storage, with initiation of support for evaluation of a cavern storage project, support of heat pipe technology and start of work on an innovative zeolite chill storage method. Work on these tasks continued through the end of fiscal year 1983 (September 1983). 


\subsection{AQUIFER THERMAL ENERGY STORAGE TECHNOLOGY}

Aquifer thermal energy storage (ATES) technology is based on the widespread existence of natural groundwater systems from which water can be pumped in large quantities to be heated or cooled and then reinjected for future withdrawal. This section considers system design and operation, aquifer characteristics, energy storage efficiency, field studies, laboratory studies, numerical modeling, environmental/ institutional factors, regional applicability, and comparison with other storage technologies.

\subsection{SYSTEM DESIGN AND DPERATION}

\subsubsection{General Concept}

An ATES installation in its simplest form is composed of a pair of ordinary water wells drilled into an aquifer as shown in Figure 1 (Reilly, Brown and Huber 1981a). During operation, the groundwater is withdrawn from the supply well, heated (or chilled) in a heat exchanger, and then returned to the same aquifer through the storage well. The two wells are horizontally separated to ensure that the storage "bubble" is unaffected by operations at the suppiy well. Thermal energy is stored in the aquifer until needed. At recovery the storage well is pumped and the hot (or chilled) water is circulated through a heat exchanger to recapture the stored energy and then returned to the aquifer through the supply wel?. The thermal energy can then be employed for space or process heating (cooling), thus reducing the need to generate primary energy. The concept is simpie and relatively efficient.

The key to ATES effectiveness is that the recovered energy is energy that would have been wasted or unavailable without seasonal storage, generally because no demand existed for it at the time of availability. This pervasive mismatch of energy supply and demand over time makes ATES attractive (Meyer and Hausz 1980).

As with other energy storage technologies, ATES is characterized by a net energy loss. Depending upon system design and aquifer characteris- 


\section{SEASONAL THERMAL ENERGY STORAGE}

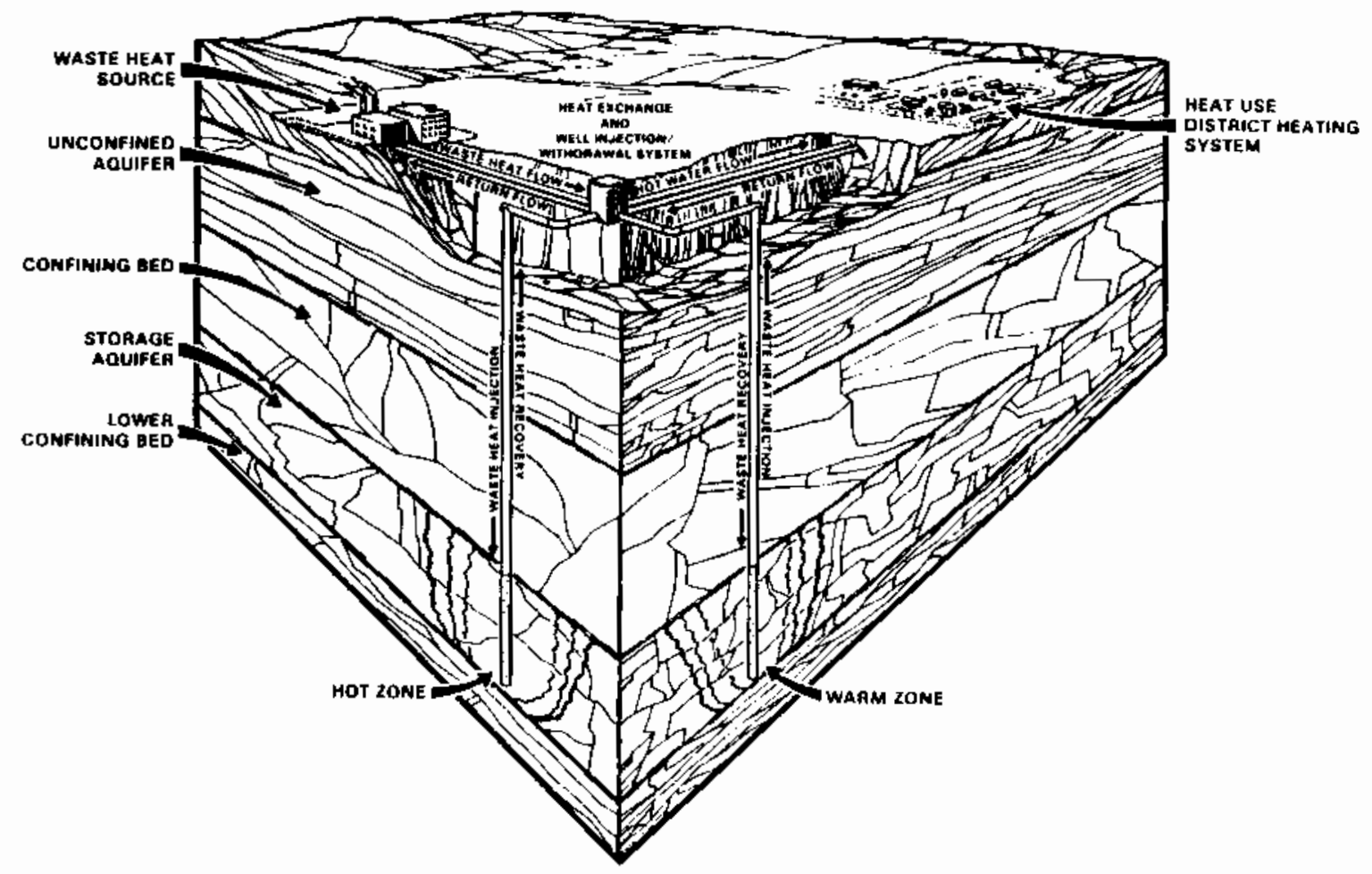

FIGURE 1. Aquifer Thermal Energy Storage

tics, oniy approximately 50 to $90 \%$ of the input energy can be recovered for beneficial use. The remainder is dissipated to the surroundings.

Both the dual and the more practical multiple well arrangements maintain most of the water within the aquifer throughout the operational and storage periods because water withdrawn is reinjected imilediately after passage through the heat exchanger. Computer models and experimental field data indicate that thermal recovery efficiencies may exceed $70 \%$ for confined aquifers from which water is pumped at reasonable flow velocity (Raymond 1980). Efficiencies for shallow unconfined aquifers may be lower unless an unsaturated zone of reasonable thickness prevents dilution by surface waters and thermal losses to the atmosphere (Alien 1979). 
Economic feasibility of warm water storage at temperatures up to $100^{\circ} \mathrm{C}$ is believed to be adequate. Evaluation of high temperature $\left(>100^{\circ} \mathrm{C}\right)$ water storage is being field tested at St. Paul, Minnesota (Section 3.4.2). The economic utilization of chilled water systems remains to be demonstrated (Brown 1983).

\section{1 .2 Sources of Heat and Chill}

Aquifer thermal energy storage, like any storage technology, can be effective only if a relatively inexpensive source of energy is available. In general, three major sources of thermal energy will be avaitable for storage: cogenerated heat, climate-related energy, and industrial waste heat.

Cogeneration is the simultaneous production of electricity and heat in the same facility, generally in constant proportions. This energy production mode is desirable because of its high efficiency: approximately $85 \%$ of the fuel's energy content is made available as electricity and hot water, as compared with an overall generation efficiency of roughly $33 \%$ in conventional electric plants. Despite this gain in efficiency, cogeneration is not widely practiced in the United States because the heat is generated according to electrical demand (electricity is usually the primary product), which seidom coincides with the dernand for heat. Hence, the continual problem is one of too little or too much heat to meet the demand, making the technology impractical for many applications. The availability of an efficient form of iong-term storage for large amounts of heat (such as ATES) can make cogeneration attractive for many uses. Even if a storage efficiency of only $60 \%$ is available, the overail efficiency of the cogeneration/storage installation would be approximately $51 \%$, a considerable improvement over conventional power generation modes (Meyer et a1. 1977).

The second class of mismatched supply and demand is the use of climate "energies of opportunity" for heating and cooling buildings. Winter chill is readily available in the form of snow, cold air, or cold surface water. Seasonal storage can make this energy available for summer air conditioning. Likewise, sumner insolation can be captured for winter 
heating. In higher latitudes, where winter daylight is limited in duration and intensity, seasonal storage provides the only means of employing solar energy for significant amounts of space heating. In lower latitudes it may facilitate the cost-effective use of solar energy by reducing or eliminating backup systems normally required for solar installations.

Industrial waste heat is the third class of energy available for seasonal storage. Seasonal storage of this year-round supply would extend its possible applications, and simultaneously reduce the need for expensive heat dissipation equipment at the plant sites.

\subsubsection{Potential Markets}

The market for thermal energy withdrawn from ATES systems is extensive, limited only by the economics of application. The market falls naturally into two segments: space heating and cooling and industrial process heat. Total national energy consumption in 1981 was 73.9 quads. Space heating and cooling of residential and commercial sectors (including hot water for sanitary purposes) accounted for approximately $25 \%$ of tota] consumption, or 18.5 quads. Process steam and direct heat in the industrial sector represents roughly $20 \%$ of the total, or 14.8 quads.

Various investigations estimate that up to $55 \%$ of the nation's space heating and cooling demands could be economically provided by conventional hot water district heating/cooling systems (Karkheck, Powell and Beardsworth 1977). It is unclear how many existing installations could benefit from the added reliability and reduced system cost offered by ATES systems, but this number is likely significant. Up to $10 \%$ of the nation's total energy consumption could be provided by ATES process heat systems (Intertechnology Corporation 1977). Finaliy, agriculture and aquaculture appear to hold unlimited potential for the utilization of waste heat, at least from a technical viewpoint. Numerous pilot operations have demonstrated the ability of properly applied waste heat to increase the yield of existing crops and to enabie cultivation of crops in areas previously too cold for those particular crops. A cost-effective agricultural operation using seasonally-stored energy remains to be demonstrated. 


\subsection{AQUIFER CHARACTERISTICS}

Aquifers are units of permeable rock or unconsolidated sediments that contain and conduct water. Most aquifers are of sedimentary origin and are either flat-lying or gently dipping within a particular locale. Aquifers range in depth from surface deposits to formations several kilometers below ground surface. Confined aquifers are bounded above and below by strata with very low permeabilities, which prevent vertical transport of water out of the aquifer. Confined aquifers are saturated with water at pressures determined by the elevations of their recharge areas. Hydraulic connections between confined aquifers and sources of supply are usually through "windows" or fracture systems in the confining layers, each horizontally removed from the zone of confinement. Because of their large volumes of available containment, aquifers have been used to store natural gas and liquid wastes. Their potential use to store water at high or low energy levels is a relatively new concept inspired by the need to manage energy efficiently (Allen 1979).

\subsubsection{Geohydrology}

Features of confined aquifers that coincide with design requirements include 1) large volumes on the order of $10^{7} \mathrm{kl}, 2$ ) low therma? conductivities of overlying and underlying strata, 3) discovery water pressures sufficient to store thermally conditioned water, 4) sufficiently high transmissivity to accept high input and supply high output rates, 5) fluid migration rates sufficiently low to maximize thermal containment and recovery, 6) environmental acceptability, and 7) geographic proximity to energy supply and consumption points. For unconfined aquifers, those without a sealing caprock, the third condition does not apply. Relatively near-surface aquifers of this type may be economically utilized over modest temperature ranges because of lower drilling and pumping costs.

\subsubsection{Petrology}

Quartz sands and sandstones are the most promising aquifers for low temperature and chill storage. Appropriate aquifer depths are likely to 1 ie between 50 and $500 \mathrm{~m}$. To contain superheated water, a confined aquifer at sufficient discovery pressure would be needed. 
Limestones and dolomites may qualify as aquifers on the basis of porosity and permeability, but lateral and vertical reservoir extent may be difficult to determine. Carbonate rocks may not contain energy efficiently because of high ratios of reservoir wall area to reservoir volume. The presence of reactive calcite and dolomite would tend to increase the salinity of the working fluid with concomitant probability of carbonate mineral precipitation. Nevertheless, these extensive formations may be feasible in some locales dominated by carbonate bed rock (e.g., the Florida peninsula).

Rock types with storage volume constituted from primary or secondary fractures or sporadic interbeds or lenses include shale, intrusives, volcanics, and metamorphic rocks. Although water quality may be exceptionally high, as in siliceous Precambrian gneisses, the total reservoir volume is not likely to be either sufficient or calculable for ATES.

\subsubsection{Regional Occurrence}

Major aquifers, shown in Figure 2, underlie about two-thirds of the area within the 48 conterminous states (Gallagher 1981). The dominant regions include the Atlantic coastal plain, the Gulf coastal plain and Mississippi embayment, the north and north-central midwest, the central Great Plains, the Columbia River plateau, and the Sacramento-San Joaquin valley. Even in areas not identified as favorable, local aquifers may accommodate ATES systems. For example, North and South Dakota are underlain by widespread Mesozoic sandstones and limestones not shown in Figure 2. In any region, subsurface exploration with drilling, core extraction and testing, and hydrologic testing will be required to prove necessary reservoir characteristics.

\subsubsection{Environmental Assessment}

The U.S. Department of Energy (1981) performed an environmental assessment of the aquifer thermal energy storage program. This assessment examined the probable environmental consequences of developing and applying ATES to reduce the nation's dependence on imported oil. The major findings are summarized as follows: 


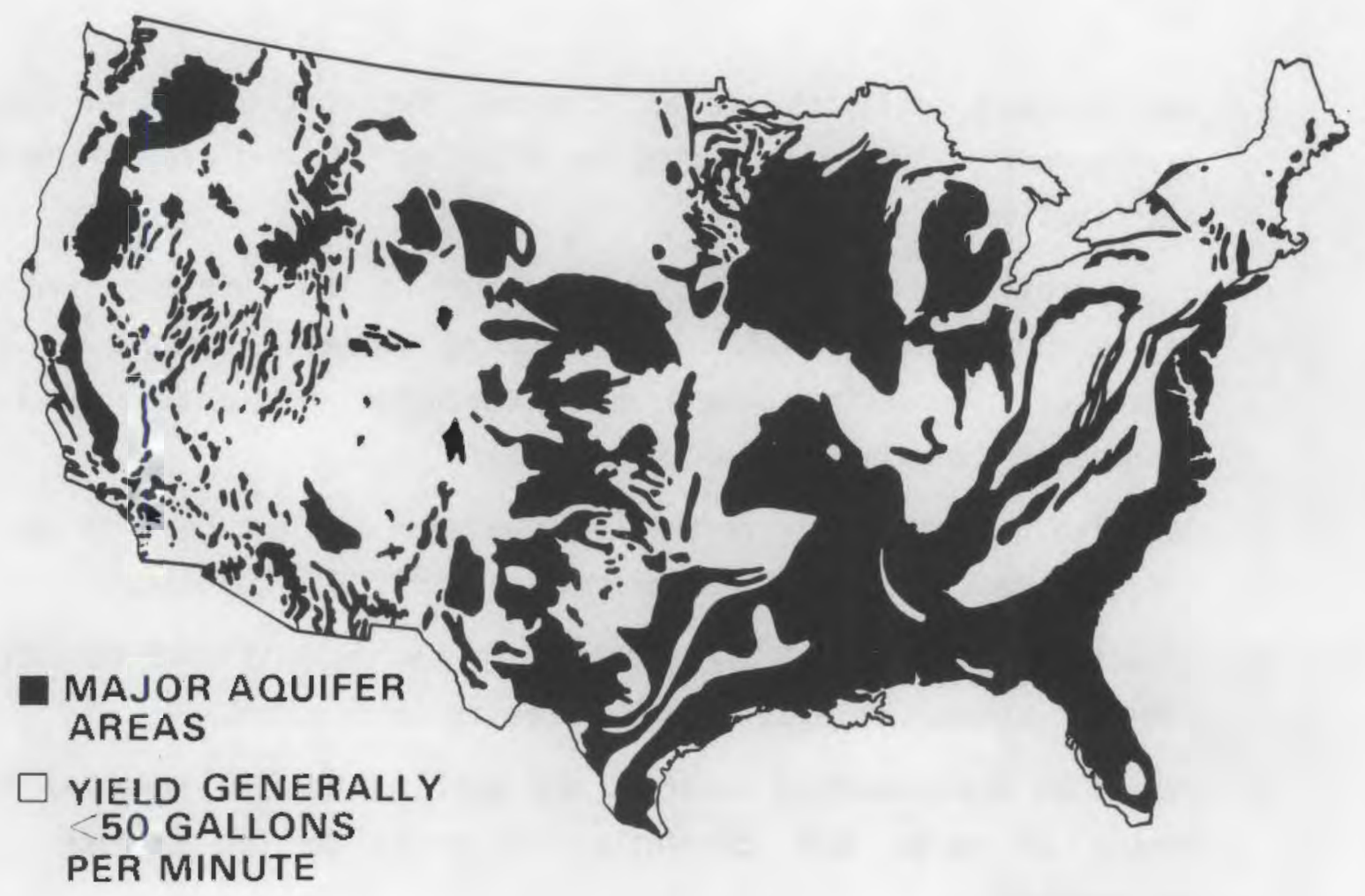

FIGURE 2. Major Aquifer Areas of the United States

1. ATES operations could reduce aquifer permeability and alter groundwater quality and groundwater microbiology. These potential impacts can be prevented (or mitigated) if systems are properly located and designed and if careful monitoring and aquifer testing are included in the project's operation.

2. A properly designed, constructed, and operated ATES facility is not expected to affect surface-water hydrology and aquatic ecology. Limited interaction is anticipated between surface waters and ATES operations.

3. No significant geologic impacts are anticipated because existing storage media (aquifers) will be used, resulting in little modification to the geologic environment.

4. The construction and operation of an ATES facility are unlikely to have major adverse socioeconomic impacts on the facility's host community because of the modest size of ATES facilities. 
5. Few land-use conflicts are anticipated, but restrictions on the development of land surrounding the ATES facility and along attendant distribution lines are likely.

6. Site-specific institutional issues related to water use are expected to be important for ATES demonstration projects because of potentially competing demand for groundwater resources. ATES represents a nonconsumptive use of water.

7. Negative impacts on terrestrial ecosystems are expected to be insignificant because of the modest size of ATES facilities.

8. Impacts on air quality are expected to be insignificant because limited interaction with air resources is anticipated.

9. Potential environmental benefits are anticipated from reducing the amount of waste heat currentily discharged to the surface environment.

10. Potential environmental benefits are anticipated from reducing dependence on conventional energy sources and thereby lessening their attendant pollution emissions and effluents.

Based on a review of these findings, it was recommended that no significant adverse environmental impact be declared for ATES program activities.

\subsection{ENERGY INJECTION, STORAGE, AND RECOVERY}

The aquifer thermal energy storage cycle involves some loss/gain in temperature during injection, storage, and recovery. Standard heat transfer mechanisms operate because of temperature differences. Other losses in efficiency may occur because of decreasing reservoir permeability, especially at and near the wellbore "sand face" region. Degradation within the heat exchanger may take place because of scaling, corrosion, or precipitation of large amounts of solute, such as calcium carbonate. 


\subsubsection{Energy Losses}

The three principal causes of energy loss in an ATES system are heat loss/gain from conduction, natural convection, forced convection, and water commingling; increase in the effective thermal resistivity of the heat exchanger; and increase in the pumping energy required to withdraw and reinject water. Energy losses must be held to the lowest practicable value. Heat losses (and gains) can be lessened by insulating wellbores and controlling the geometry of water bubble development to minimize the vertical dimension within a highly permeable segment of the reservoir. Transfer of heat between the working fluid and the solid and fluid reservoir boundaries is most detrimental during the first several cycles of operation.

The range of efficiency experienced in field experiments and demonstrations has been generaliy 30 to $85 \%$. Lack of water containment and natural convection caused by vertical density gradients are especialiy negative factors. The subject of efficiency is explored further under Sections 3.4 and 3.6 .

\subsubsection{System Impairment Mechanisms}

Mechanisms of system impaiment are physical, chemical, and biological processes that impede water flow, reduce heat transfer, or otherwise interfere with system operation. These mechanisms may be classified broadly as follows:

1. particulate plugging

2. chemical precipitation

3. liquid-solid reactions

4. formation disaggregation

5. oxidation reactions

6. biological activity

Table 1 identifies, ranks, and exemplifies the mechanisms, both known and inferred, that may act to adversely affect the functioning of ATES systems. Each mechanism listed is a generic chemical, physical, or 
biological process specifically related to the ATES cycle and range of environments. These processes, in general, may contribute to particulate plugging and loss of permeability.

TABLE 1. Physical, Chemical, and Biological Processes That Can Impact Aquifer Thermal Energy Storage

Estimated Relative

Importance

\section{I (greatest)}

II

I I

II

I I

II

II

III

I I

II I

IV

IV (least)

\begin{tabular}{l} 
Mechanism \\
\hline Particulate plugging (1) \\
Precipitation from \\
working fluid (scaling)(2) \\
Dispersion of clay \\
mineral particles (3) \\
Bacteria multiplication (6)
\end{tabular}

Corrosion of metal components (3)

Suspension and transport of existing fines (1)

Mechanical erosion (4)

Differential therma 1 expansion (4) Reservoir fatigue $(a)$

Hydrolysis of silicates, carbonates, and sulfates (3)

Reservoir cement dissolution (3)

Oxidation of reservoir or caprock minerals (5)
Example

A11 causes

Calcium carbonate, silica, barium sulfate

Montmorillonite leached with fresh water

Sulfate-reducing bacteria, ironoxidizing bacteria

Carbonic acid, sulfuric acid, oxidation, electrochemical

External silt, indigenous uncemented sediment

Sandface and nearwellbore region

Quartz vs. calcium carbonate

Static or cyclical dynamic

Orthoclase to kaol inite; hydrolytic weakening

Calcite, silica

Pyrite, galena, sphalerite

\section{(a) Coupled with differential thermal expansion}

Note: Numbers in parentheses correspond to the list of mechanisms in the preceding paragraph. 


\subsubsection{Beneficiation Procedures}

Reservoir and system beneficiation refer to operating methods that minimize the effects of scaling, corrosion, biofouling, and particulate plugging (McCune 1977). Scaling tendencies are indicated by high $\mathrm{pH}$ and high concentration of such ions as barium, strontium, iron, magnesium, carbonate, and sulfate (McCune 1977; Vetter and Campbel1 1979). Corrosion problems are associated with dissolved and suspended iron compounds, presence of hydrogen sulfide, and low ph.

Scaling and corrosion may be interdependent (Kreitlow 1977). For example, corrosion products of copper, iron, and zinc tend to increase the rate of silica deposition. A layer of scale coating that is thin, dense, adherent, and complete will greatly reduce the rate of corrosion. On the other hand, a patchy scale coating will tend to concentrate corrosion in the open areas, and pitting will result. The corrosion rate of mi\}d stee? in water is greatly reduced by the formation of a thin adherent layer of calcium carbonate scale; this explains why hard water is less corrosive than soft water.

Biofouling or particulate plugging may originate from suspended organic materials or from inorganic minerals, especialiy clay particles.

The Drillers Journal (1965) describes procedures for maintaining the yields of water wells. These include installation of well screens with high intake areas; hydrochloric or sulfamic acid injection to dissolve scale; bactericide injection to eliminate slime; and addition of a sequestering agent to relieve silt or clay plugging.

The subject of reservoir and system beneficiation is too extensive for detailed description in this chapter. However, some of the control techniques applied to major negative effects are listed in Table 2.

\subsection{DOMESTIC FIELD STUDIES}

The most significant ATES field studies in the United States have been instituted and supported by the U.S. Department of Energy. These experiments are described with respect to field development, experimental conduct, performance, and conclusions. An ongoing commercial air 
TABLE 2. Beneficiation Techniques for Countering Major Physical, Chemical and Biological Processes Associated with Well Operations

\begin{tabular}{|c|c|}
\hline Processes & Beneficiating Techniques \\
\hline Scale formation & $\begin{array}{l}\text { Acidification } \\
\text { Slurry seeding } \\
\text { Chelation } \\
\text { Surfactant treatment } \\
\text { Ion exchange }\end{array}$ \\
\hline Corrosion & $\begin{array}{l}\text { Inhibitors } \\
\text { Resistant alloys } \\
\text { Protective coatings } \\
\text { Nonmetallic materials } \\
\text { Insulation and depolarizing } \\
\text { agents }\end{array}$ \\
\hline Biofouling & $\begin{array}{l}\text { Cleaning } \\
\text { Acidification } \\
\text { Microbiocide treatment } \\
\text { Surfactant treatment } \\
\text { Backflushing/agitation }\end{array}$ \\
\hline Particulate plugging & $\begin{array}{l}\text { Use of connate aquifer water } \\
\text { as the working fluid } \\
\text { Well completion with } \\
\text { reaming and gravel packing } \\
\text { Soil fixing by cementation } \\
\text { Avoidance of clay minerals, } \\
\text { especially in near-wellbore } \\
\text { regions } \\
\text { Avoidance of water softening } \\
\text { (from Ca to } \mathrm{Na} \text { ) or } \\
\text { water dilution }\end{array}$ \\
\hline
\end{tabular}

conditioning experiment, in place at Tuscaloosa, Alabama, has received partial DOE support.

\subsubsection{Mobile, Alabama, Field Test Facility (FTF)}

Auburn University, under federal sponsorship, started an ATES research project in 1975 at a test site near Mobile, Alabama. Initial work involved injecting heated water from a power plant into a confined aquifer. The experiment involved the injection and recovery of $7570 \mathrm{~m}^{3}$ of water. Injection water at $37^{\circ} \mathrm{C}$ was obtained from the effluent discharge 
canal of a power plant. The temperature of formation water in the aquifer was about $20^{\circ} \mathrm{C}$. Injection, storage, and recovery periods were 420,1416 , and 2042 hours, respectively. Recovery was terminated when the water temperature reached $21^{\circ} \mathrm{C}$. About $67 \%$ of the injected energy was recovered. Injection well plugging posed a major problem. The high level of suspended solids in the injection water was the primary cause (Molz, Parr, and Andersen 1979).

A second experiment, shown in Figure 3, involved injection and recovery of $54,900 \mathrm{~m}^{3}$ of water. Water was pumped from an unconfined aquifer, heated in a boiler to about $55^{\circ} \mathrm{C}$, and injected into the confined aquifer. Injection, storage, and recovery periods were 1900, 1213, and 987 hours, respectively. Recovery was terminated when the water temperature declined to $33^{\circ} \mathrm{C}$. About $65 \%$ of the injected energy was recovered. Plugging problems were much reduced during the second experiment. Buoyancy effects caused by convection of the heated water in the aquifer caused little decrease in recovery efficiency. A subsequent test was completed under similar conditions and with similar results, except that heat recovery was somewhat better (76\%) because the aquifer and adjacent confining beds had been preheated by the previous cycle (Molz, Parr, and Andersen 1979).

In 1980 the Mobile field test facility was revised to a true doublet ATES system with production and injection from the same aquifer. A conceptual well doublet system is shown in Figure 4. New injection, supply, and monitoring wells were drilled. Three cycles of heat injection tests were conducted.

In the first cycle, $26 \times 10^{3} \mathrm{~m}^{3}$ of water heated to $58^{\circ} \mathrm{C}$ were injected into the aquifer in 30 days at an average rate of about $9.8 \mathrm{l} / \mathrm{sec}$. Water recovery began at $12.6 \mathrm{l} / \mathrm{sec}$ after 30 days of storage. Water temperature declined linearly from $55^{\circ} \mathrm{C}$ to $35^{\circ} \mathrm{C}$ during recovery over 24 days of pumping. The recovery factor was 55.2\% (Melville et al. 1981).

Fifty-eight thousand cubic meters of water at an average temperature of $82^{\circ} \mathrm{C}$ were injected into the aquifer over 135 days during the second cycle. After storage for 34 days, water recovery began at $12.6 \mathrm{l} / \mathrm{sec}$. 


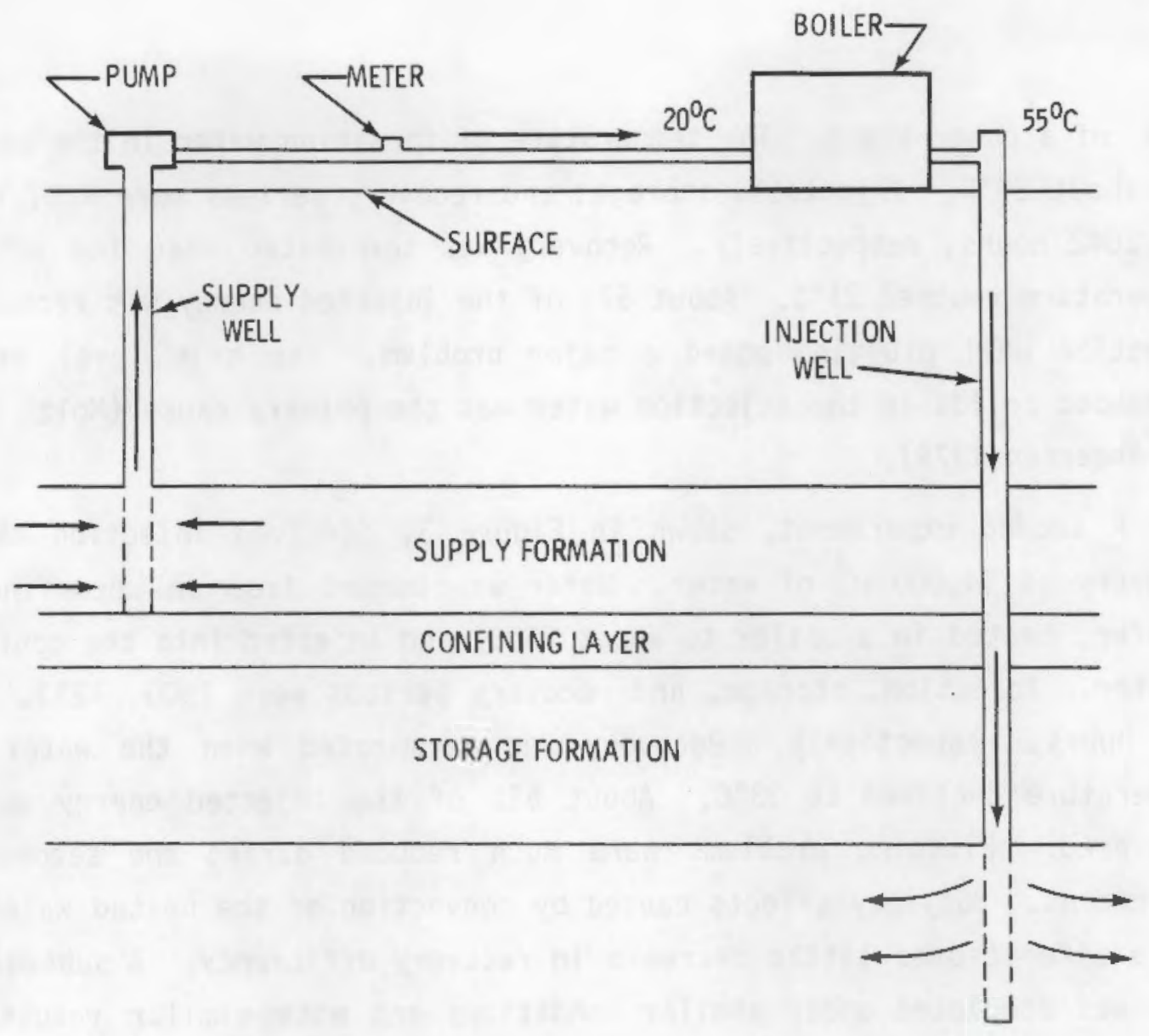

FIGURE 3. Schematic of Second Aquifer Experiment at Auburn University

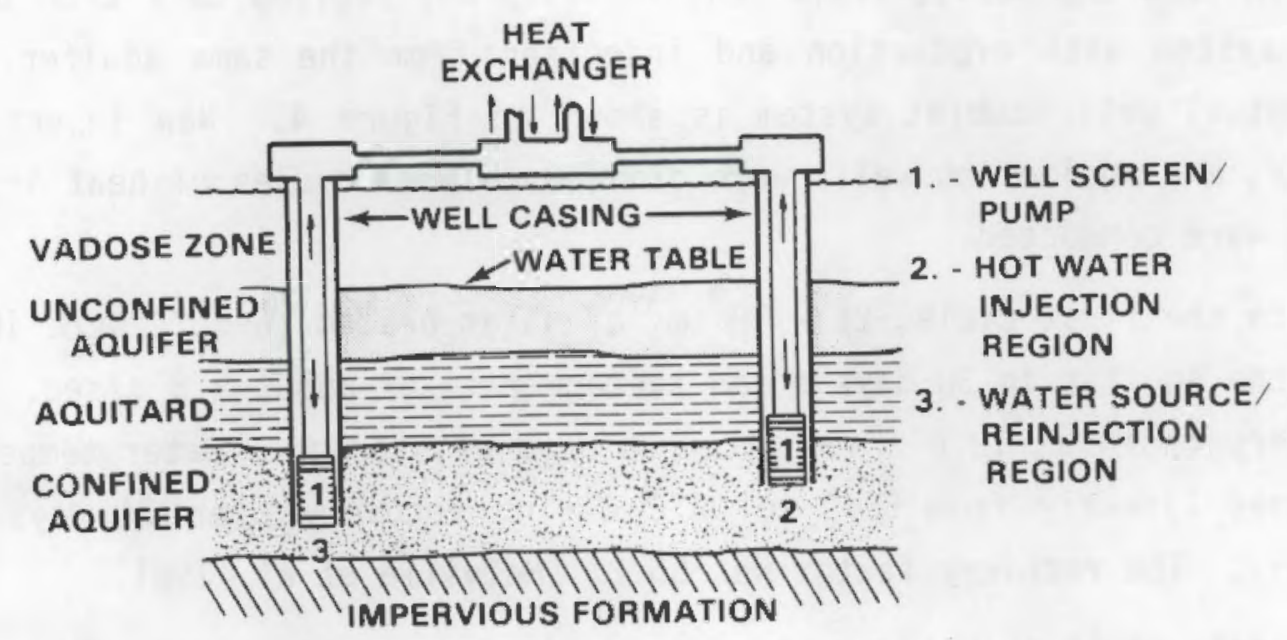

ARROWS SHOW REVERSIBLE FLOW

FIGURE 4. Conceptual Well Doublet System Installed in Confined Aquifer 
The initial recovery temperature was only $56^{\circ} \mathrm{C}$, and temperatures in the monitoring wells showed the adverse influence of convective flow caused by therma] buoyancy. The test was stopped after 2 weeks of pumping. The recovery well was modified to draw water only from the upper half of the aquifer. The test was continued, with an initial increase of $2.5^{\circ} \mathrm{C}$ in temperature of the recovered water. However, temperature decreased at the same rate as before well modification, and the final recovery factor was only $45.2 \%$. The reservoir temperature distribution at the end of storage is shown in Figure 5 .

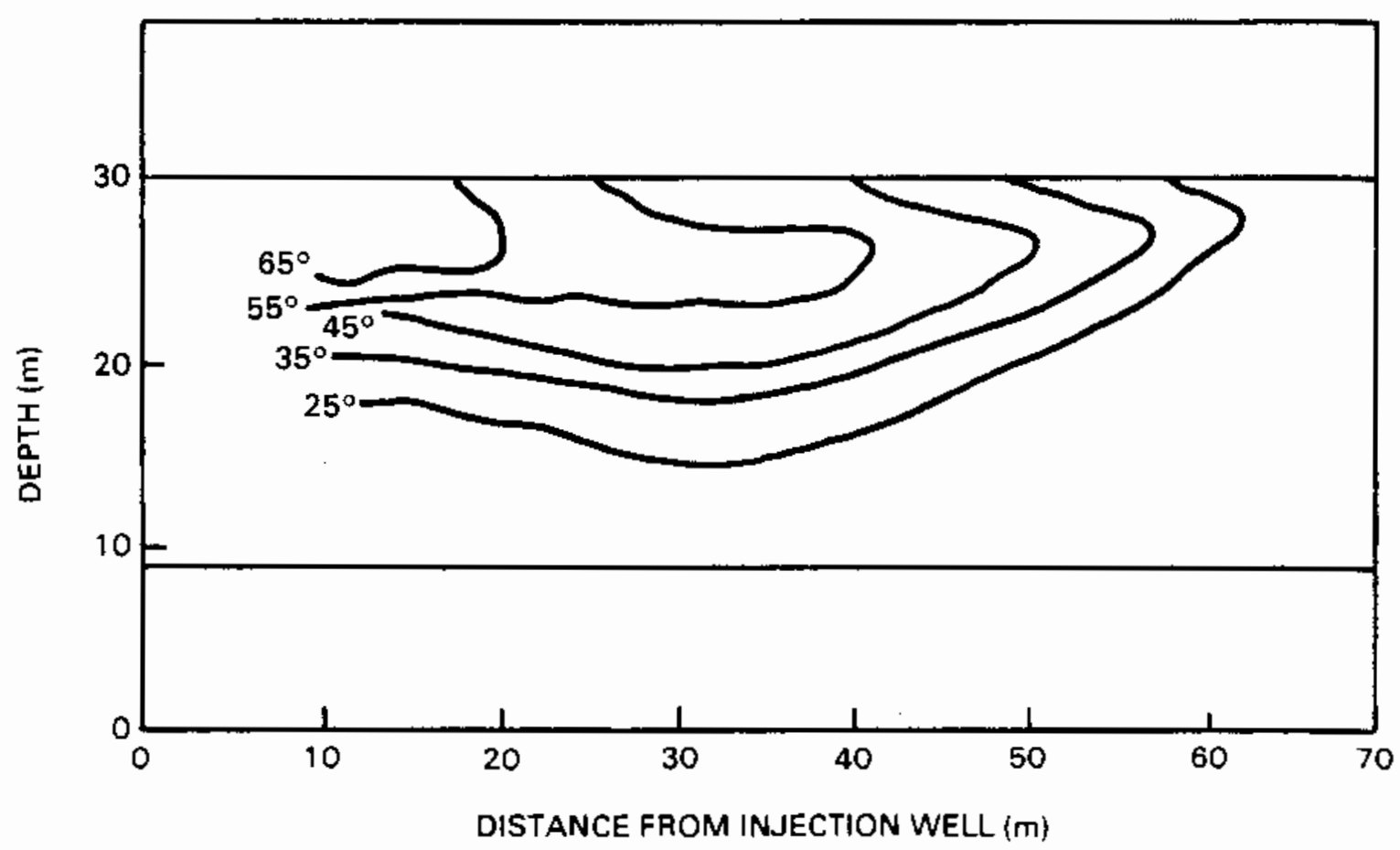

FIGURE 5. Temperature Distribution After the Second Cycle Storage Period, Mobile FTF

In the third cycle, water temperature and injection volume were essentially the same as for the second, but the recovery scheme was altered. The modified injection/recovery well was used to inject water into the upper half of the aquifer. A second well was drilled close to the injection/recovery well and completed in the lower part of the aquifer. A pump installed in the second well was operated simuitaneously 
with recovery well pumping. The rationale was to extract cooler water from the bottom of the aquifer and thus prevent it from diluting hot water near the top. This scheme was unsuccessful, and a recovery factor of only $42 \%$ was realized. More complex injection/recovery systems are needed for efficient recovery of heated water at higher temperatures in aquifers that have relatively high permeabilities and transmissivities (Melville, Molz, and Guven 1982).

Data analysis produced the following conclusions:

1. A layer of high intrinsic permeability exists near the horizontal center plane of the aquifer around the injection well. During injection, much of the flow occurred within this layer, which caused significant lateral spreading of the injected volume.

2. During storage, thermal convection in and above the high permeability Tayer, coupled with conduction, caused more lateral distribution of the heat.

3. Hot water in the top of the aquifer, having spread over a large area, resulted in a large conductive heat loss to the upper confining layer.

4. The selective, dual recovery system had a very minor effect because the aquifer nonhomogeneity at the location of the current experiments and anisotropy controlled the fluid velocity distribution to a significant extent.

Because of the above phemomena, the initial production temperature in cycle 3 was $51.5^{\circ} \mathrm{C}$, well below the average injection temperature of $79^{\circ} \mathrm{C}$, and the recovery factor of cycle 3 was $42 \%$.

The degree of aquifer nonhomogeneity inferred at this location was not apparent during previous experiments at a location only $109 \mathrm{~m}$ away. Therefore, aquifers with the same transmissivity can behave quite differently in a thermal energy storage sense. Vertical variations of horizontal hydraulic conductivity are difficult to detect, and moderatescale hot water injection testing aiong with computer simulation may be an economical procedure for making an overall and final evaluation of an aquifer's suitability for ATES. 


\subsubsection{St. Paul, Minnesota, Field Test Facility (FTF)}

The University of Minnesota ATES Demonstration Project, originally installed at St. Paul, has been converted to a high-temperature ATES field test facility (FTF) with the capability of injection up to $150^{\circ} \mathrm{C}$ (Allen and Raymond 1982). Aquifer characterization and short-cycle heat injection tests were conducted. The aboveground equipment installation includes line-shaft turbine pumps in two production wells (Walton 1981).

The Phase I test program was originally conceived as a 5-MW thermal input/output test facility to perform a series of 24-day test cycles entailing 8 days of heat injection, 8 days of storage, and 8 days of heat recovery. The purpose was to acquire engineering parameters needed to design an aquifer seasonal heat storage facility for the University of Minnesota heating plant with a maximum power input/output of $20 \mathrm{MW}$ therma1. The system comprises two primary pumping we11s, $255 \mathrm{~m}$ apart, with a design capacity of about $19 \mathrm{l} / \mathrm{sec}$ and maximum water injection temperature of $150^{\circ} \mathrm{C}$. The primary wells are surrounded by an array of monitor wells and connected to surface piping through a tube and shell heat exchanger. Heat is supplied to the heat exchanger by steam from the St. Paul campus heating plant of the University of Minnesota.

The site is near the center of the large Twin Cities Artesian Basin, which contains several major aquifers in well-stratified lower Paleozoic sandstones and dolomites separated by shaly confining beds (Walton 1981; Walton and Hoyer 1982). Both purnping wells are completed in the Franconia-Ironton-Galesville (FIG) aquifer, which comprises fine- to medium-grained sandstones with numerous thin shale interbeds. The aquifer is approximately $63 \mathrm{~m}$ thick, $181 \mathrm{~m}$ below ground surface at the injection we11, and has an artesian head of $125 \mathrm{~m}$. The stratigraphic and hydrologic complexity of the FIG aquifer are shown in Figure 6 .

The dimensions of the monitoring well array were determined by the thickness and storage coefficient of the aquifer, the desired length of test cycles, and the pumping rate. These parameters dictated a tight array with two sets of monitor wells $7 \mathrm{~m}$ and $14 \mathrm{~m}$ from the storage well (Figure 7), instrumented with pressure transducers and thermocouples at a 


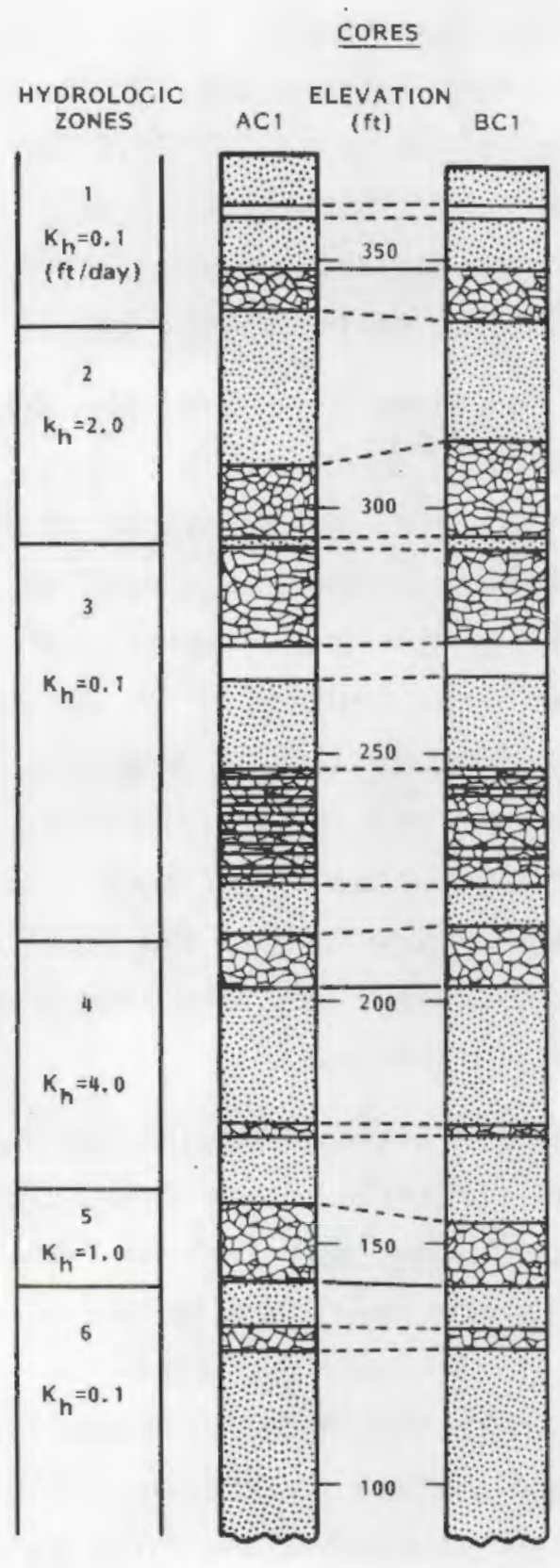

LITHOLOCIES

ST. LAWRENCE FORMATION

DOLOMITIC SILTSTONE AND INTRACLASTIC CONGLOMERATE. MASSIVE MUDSTONE.

SILTY DOLOMITE, DOLOMITIC SILTSTONE AND INTRACLASTIC CONGLOMERATE.

\section{FRANCONIA FORMATION \\ RENO MEMBER}

FINE AND VERY FINE GLAUCONITIC FELOSPATHIC SANDSTONE.

$$
\text { MAZOMANIE MEMBER }
$$

FINE DOLOMITIC FELDSPATHIC SANDSTONE, INTRACLASTIC CONCLOMERATE AND THIN SHALE. SPARSE GLAUCONITE, SOME FRIABLE ZONES.

\section{RENO MEMBER}

FINE AND VERY FINE GLAUCONITIC FELDSPATHIC SANDSTONE AND SILTSTONE. HICHLY BURROWED.

SILTY AND SANDY DOLOMITE.

FINE AND VERY FINE GLAUCONITIC FELDSPATHIC SANDSTONE AND SILTSTONE. MANY BEDS BURROWED AT TOP.

FINE CLAYEY SANDSTONE. "MUSTARD BED".

FINE HICHLY GLAUCONITIC SANDSTONE.

$$
\text { TOMAH MEMBER }
$$

INTERBEODED FINE AND VERY FINE GLAUCONITIC FELDSPATHIC SANDSTONE AND SHALE. MOTTLED AND LAMINATED BEDS.

INTERBEDDED FINE SILTY FELDSPATHIC SANDSTONE AND SHALE. BIRKMOSE MEMBER

SILTY DOLOMITE AND DOLOMITIC SILTSTONE.

FINE CLAUCONITIC FELDSPATHIC SANDSTONE, MINOR SHALE. MOTTLED AND LAMINATEO BEDS.

\section{IRONTON AND GALESVILLE FORMATIONS}

MEDIUM AND COARSE QUARTZOSE SANDSTONE. CROSS-BEDDED . SOME VERY FRIABLE ZONES.

FINE OUARTZOSE SANDSTONE WITH SHALE STRINGERS.

MEDIUM ANO FINE QUARTZOSE AND FELDSPATHIC SANDSTONE WITH SHALE STRINCERS. FRIABLE.

FINE AND VERY FINE FELOSPATHIC SANDSTONE WITH SHALE STRINCERS.

\section{EAU CLAIRE FORMATION}

INTERBEDDED SILTY, VERY FINE FELDSPATHIC SANDSTONE AND SHALE.

SHALE.

INTERBEDDED VERY FINE SANDSTONE AND SHALE.

FIGURE 6. Summary of Lithologies and Hydrologic Zones of the FranconiaIronton-Galesville Aquifer and Confining Bed, St. Paul Field Test Facility 
number of points within the aquifer and in the overlying and underlying beds, to measure changes in pressure and temperature and to permit the collection of water samples. These instruments are hard-wired directly into a 100-channel digital data logger and tape recorder. A major goal of the program was to test the feasibility of storing and recovering water at relatively high temperatures. The system is designed to inject water up to $150^{\circ} \mathrm{C}$ and return water to the supply well after heat extraction at a temperature of $84^{\circ} \mathrm{C}$. The maximum $\Delta T$ of $66^{\circ} \mathrm{C}$ and pumping rate of $19 \mathrm{l} / \mathrm{sec}$ give a nominal maximum power input/output of $5 \mathrm{MW}$ thermal.

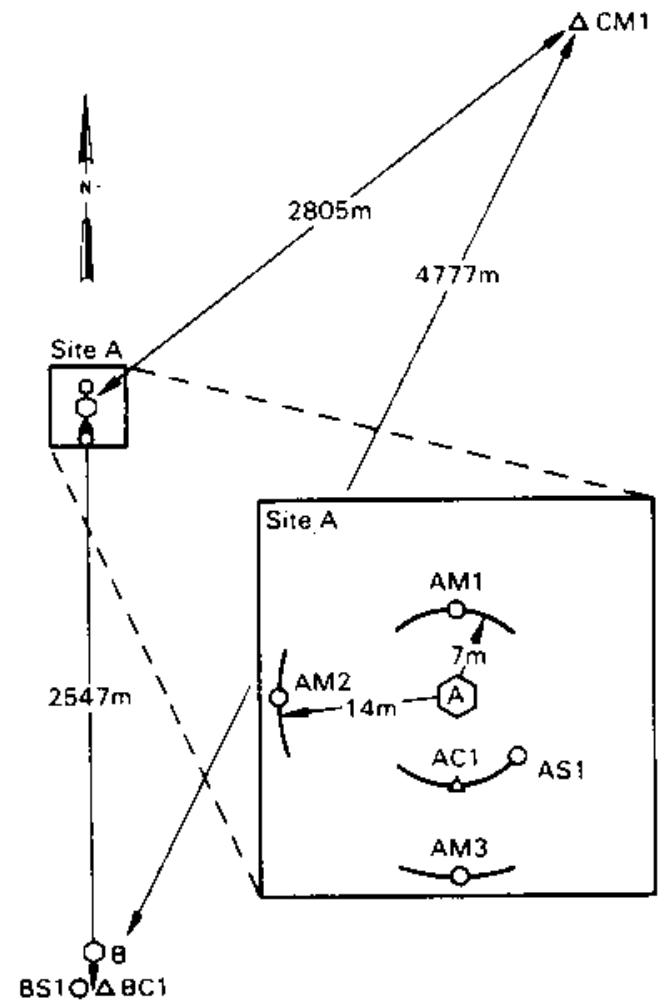

Location Diagram of Test Wells and Monitor Wells

$A=$ Heat Injection Well

B = Water Supply WeH

AC1, BC1 = Core Borings

AS1 and BS1 = Supplemental Monitor Wells for $\mathrm{AC} t$ and $\mathrm{BC} 1$

AM1, 2 and 3. CM1 = Monitor Wells

S Monitor Wells, 2 Production Wells

2 Core Boring Wells

FIGURE 7. St. Paul FTF Well Field Configuration 
Funding for the project was awarded in May 1980, and well drilling and construction started in September. Construction, instrumentation, debugging, well development, and hydraulic testing were completed in May 1982. Project delays were caused by difficulties with drilling and wel] construction in the friable and broken sandstone and dolomite aquifers that overlie the $F I G$ aquifer; by repeated failures of the pressure transducers, which required modification for deep immersion in the monitor wells; and by injection well clogging due to air entrainment and bubble formation when the back pressure in the injection well was not sufficient to maintain a continuous column of water in the injection pipe. The hydraulic testing procedure ended with a successful 8-day injection of cold water at ambient groundwater temperature $\left(12^{\circ} \mathrm{C}\right)$.

A nonisothermal radial flow model was used to examine the maximum permissible injection rate based on the aquifer's potential for hydrofracturing. The hydrofracture pressure range was calculated to be approximately one-half the lithostatic pressure, or between 2.76 and 2.86 $\mathrm{MPa}$ for the Franconia-Ironton-Galesville aquifer. Using $2.86 \mathrm{MPa}$ as the maximum allowable pressure, the model indicated a maximum injection rate of $2500 \ell / m i n$. The potential for hydrofracturing does not appear to be serious, because $1136 \mathrm{\ell} / \mathrm{min}$ is the maximum rate planned for injection.

Step-drawdown tests were run on the injection/production doublet wells, designated $A$ and $B$, to determine well efficiencies. Production we 11 B was developed by the pump and surge method for approximately $10 \mathrm{hr}$. The maximum rate pumped during well development was $3218 \mathrm{l} / \mathrm{min}$ for approximately $4.75 \mathrm{hr}$; maximum drawdown was approximately $125 \mathrm{~m}$ below land surface. The well recovered for approximately $12 \mathrm{hr}$ and measured water levels were within $6.1 \mathrm{~cm}$ of the predevelopment level. This recovery was considered sufficient to conduct a step-drawdown test. Pumping took place at $833 \mathrm{l} / \mathrm{min}$ for $258 \mathrm{~min}, 1439 \mathrm{l} / \mathrm{min}$ for $217 \mathrm{~min}$, and $2783 \mathrm{\ell} / \mathrm{min}$ for 190 min. Injection well A was developed for approximately $8 \mathrm{hr}$ also with the pump and surge method. The maximum rate pumped during development was approximately $3407 \mathrm{l} / \mathrm{min}$ for $3 \mathrm{hr}$. The well recovered for approximately $18 \mathrm{hr}$ and the water level was within $9.14 \mathrm{~cm}$ of the predeveiopment level. 
Step-drawdown test pumping duration and pumping rate were 182 min at 2211 l/min and 133 min at approximately $3786 \mathrm{l} / \mathrm{min}$. Evaluation of the step-drawdown data showed an $80 \%$ efficiency for well A at a pumping rate of $1136 \mathrm{l} / \mathrm{min}$, and a $90 \%$ efficiency for well $B$ at the same pumping rate. The lower efficiency computed for well A could be caused by less than optimal well development. Nevertheless, total drawdowns computed for both wells A and B are similar; well efficiency of $80 \%$ is not expected to hinder either withdrawal or injection during testing.

A continuous-rate aquifer test was performed on well $A$. The well was pumped at an average of $1287 \mathrm{l} / \mathrm{min}$ for approximately 4.5 days. Orawdown measurements were taken in all observation wells. Drawdown data were analyzed for transmissivity and storage coefficient. A total transmissivity of $101 \mathrm{~m}^{2} /$ day and a storage coefficient of $2.55 \times 10^{-5}$ were calculated for the upper Franconia-Ironton-Galesville aquifer. Previous estimates of transmissivity based on initial drill stem tests were 28 to $33 \mathrm{~m}^{2} /$ day, indicating that a full-scale ATES project would be difficult to implement. The transmissivity of $101 \mathrm{~m}^{2}$ /day derived from the more comprehensive tests assured adequate water flow rates and appeared nearly optimal for high-temperature ATES. The 8-day cold-water injection test averaged $18.6 \mathrm{l} / \mathrm{sec}$; head buildup in the injection well (well A) equilibrated at about $304 \mathrm{kPa}$.

The first injection of hot water took place in May 1982 at $18.6 \mathrm{l} / \mathrm{sec}$ and $85^{\circ} \mathrm{C}$. This test resulted in head buildup at an increasing rate because of calcite precipitation within the well; the injection was halted after about $50 \mathrm{hr}$. An immediate attempt to backflush the well was aborted when the synthetic rubber pump shaft bearings failed in the hot water. $A$ long series of delays ensued while a means of handling the carbonate precipitation problem was developed. This outcome of hot water injection proved that the groundwater is saturated with calcium carbonate at ambient temperature. Thus, heating to $80^{\circ} \mathrm{C}$ decreased the solubility of calcite (ca)cium carbonate) by about tenfold. Injected hot water was found to be saturated with respect to both $\mathrm{Ca}^{+2}$ and $\mathrm{Mg}^{+2}$, suggesting the possibility that dolomite $\left[\mathrm{Ca}, \mathrm{Mg}\left(\mathrm{CO}_{3}\right)_{2}\right]$ also precipitated. The injection well was 
acid treated and surged to remove the precipitate and restore injectivity and specific capacity to pretest levels. Minnesota law provides that a variance must be obtained from the Minnesota Poilution Control Agency and Department of Health to reinject water into an aquifer. In granting a variance for this project, the regulatory agencies stipulated that no chemical additives could be used to treat the water.

A precipitator/filter system was designed to remove calcium carbonate between the injection well and the heat exchanger by deposition on graded high purity limestone contained within six reactors made from sections of pipe $35.6 \mathrm{~cm}$ in diameter by $1.22 \mathrm{~m}$ long. Three reactors in each of two banks were piped in parallel, and the two banks were connected in series. The reactors effectively reduced carbonate scale precipitation on the well screen and within the formation.

A planned 8-day heat injection test was temporarily halted after only 30 hours because the head loss across the reactors increased from 69 to $635 \mathrm{kPa}$ from calcite precipitation. The facility was shut down for cleaning heat exchanger tubes and regeneration of the reactors. Heat injection resumed and continued for 27 hours. Then injection was stopped because the pressure drop across the reactors reached $710 \mathrm{kPa}$. The reactors were regenerated and the heat exchanger cleaned and tube leakage repaired. The injection test was accomplished in five increments, totaling $126 \mathrm{hr}$. Mean temperature of injected water was $90.9^{\circ} \mathrm{C}$. Mean flow rate was $18.4 \mathrm{l} / \mathrm{sec}$. Mean $\Delta T$ for the heating phases was $78.9^{\circ} \mathrm{C}$. Total volume of water injected was $8328 \mathrm{~m}^{3}$.

After 11 days of storage, heat withdrawa) began. Water was pumped from well A into the supply well (wel1 B) for $126 \mathrm{hr}$. Water temperature averaged $60.2^{\circ} \mathrm{C}$ at an average recovery rate of $18.1 \mathrm{l} / \mathrm{sec}$. The recovery factor was about $59 \%$.

Temperature responses monitored in observation wells are consistent with a multilayer aquifer model. The highest temperatures recorded were $89^{\circ} \mathrm{C}$ at the most permeable levels of the Ironton-Galesville portion of the aquifer. Heat withdrawal lowered temperatures at those levels by $60^{\circ} \mathrm{C}$. 
Preliminary analysis of heat injection data indicated up to five hydraulic zones within the Ironton-Galesville aquifer. Temperature data collected on the Ironton-Galesville aquifer during heat injection showed a definite zone within the central part of the Ironton-Galesville aquifer with higher hydraulic conductivity than zones above and below it. The heat storage and recovery data indicate very little "buoyancy flow" during storage and general confinement of heat near the injection we 11.

The first short cycle injection test was completed in December 1982. Key parameters of this and subsequent cycles are given in Table 3 . In May 1983, the second short cycle injection was completed. After 10 days of storage, recovery was initiated. The bearings on the line shaft turbine failed as temperatures reached $80^{\circ} \mathrm{C}$. After 90 days of delay, redesign and installation of the line shaft bearing assemblies, the recovery was completed. The long storage period had reduced the energy storage efficiency substantially to $46 \%$. The third and fourth cycles were completed in the fall of 1983 without incident. The temperatures of injection and recovery were increased each cycle. Recovery efficiencies during these two cycles were $62 \%$ and $58 \%$, respectively.

Several features make the results of the St. Paul testing very promising for ATES. Relatively good recovery efficiencies have been obtained even though

1. relatively small volumes were injected (even considering the short storage periods)

2. injection occurred into two primary hydraulic zones, which were widely separated

3. the injection temperature was raised each time, reducing the effectiveness of previous cycle preheating of the aquifer.

After several long-term cycles involving much larger storage volumes and utilizing only the Ironton-Galesville aquifer, significantly higher storage efficiencies would probably be obtained. 
TABLE 3. Key Parameters for the Short-Term Test Cycles at the University of Minnesota ATES Field Test Facility

\begin{tabular}{|c|c|c|c|c|c|}
\hline & $\begin{array}{r}\text { Flow } \\
\text { Rate } \\
(\text { e sec I }) \\
\end{array}$ & $\begin{array}{c}\text { Mean } \\
\text { Temperature } \\
\left({ }^{\circ} \mathrm{C}\right) \\
\end{array}$ & $\begin{array}{l}\text { Volume } \\
\text { Pumped } \\
\left(10^{3} \mathrm{~m}^{3}\right) \\
\end{array}$ & $\begin{array}{c}\text { Ouration } \\
\text { (Oays) } \\
\end{array}$ & $\begin{array}{l}\text { Energy } \\
\text { Recovery } \\
\text { Factor } \\
\end{array}$ \\
\hline \multicolumn{6}{|l|}{ Cycle I } \\
\hline Injection & 18.4 & 89.4 & 8.3 & 5.2 & \\
\hline Storage & & & & 13 & 0.59 \\
\hline Recovery & 18.1 & 59.3 & 8.1 & $5.2 / 6$ & \\
\hline \multicolumn{6}{|l|}{ Cycle II } \\
\hline Injection & 17.6 & 97.4 & 12.2 & 8 & \\
\hline Storage & & & & 90 & 0.46 \\
\hline Recovery & 17.8 & 55.2 & 12.3 & 8 & \\
\hline \multicolumn{6}{|l|}{ Cycle III } \\
\hline Injection & 18.3 & 106.1 & 12.2 & 7.7 & \\
\hline Storage & & & & 9.7 & 0.62 \\
\hline Recovery & 17.8 & 81.1 & 11.8 & $7.7 / 8$ & \\
\hline \multicolumn{6}{|l|}{ Cycle IV } \\
\hline Injection & 17.9 & 114.8 & 11.9 & 7.7 & \\
\hline Storage & & & & 10.1 & 0.58 \\
\hline Recovery & 17.8 & 89.1 & 11.9 & 7.7 & \\
\hline
\end{tabular}

Phase I of the Aquifer Thermal Energy Storage field test program at the University of Minnesota ended December 7, 1983, with the completion of this fourth and final short-term test cycle performed under contract with Pacific Northwest Laboratory, prime contractor to the U.S. Department of Energy.

\subsubsection{Stony Brook, New York, Demonstration Project}

The use of unconsolidated aquifers for seasonal storage of large quantities of chill energy for recovery at a later time is appealing from 
high water yields are widespread. Storage of chill energy in aquifers is not expected to adversely affect the environment in most cases (Supkow and Skinner 1981).

An ATES chill energy storage experiment was carried out on the Stony Brook Campus of the State University of New York (SUNY) at Stony Brook, Long Island, New York, U.S.A. The site is near the north shore of Long Island near Long Island Sound (Figure 8). Figure 9 illustrates a generalized north-south cross section through Long Island at the Stony Brook site. The aquifers from the land surface downward are the Upper Glacial, the Magothy and the Lloyd. All are recharged only by rainfall on Long Island. The Upper Magothy, utilized for the ATES experiment at Stony Brook, consists of fine to medium grajned sand alternating with sandy, clay layers (Supkow and Skinner 1981).

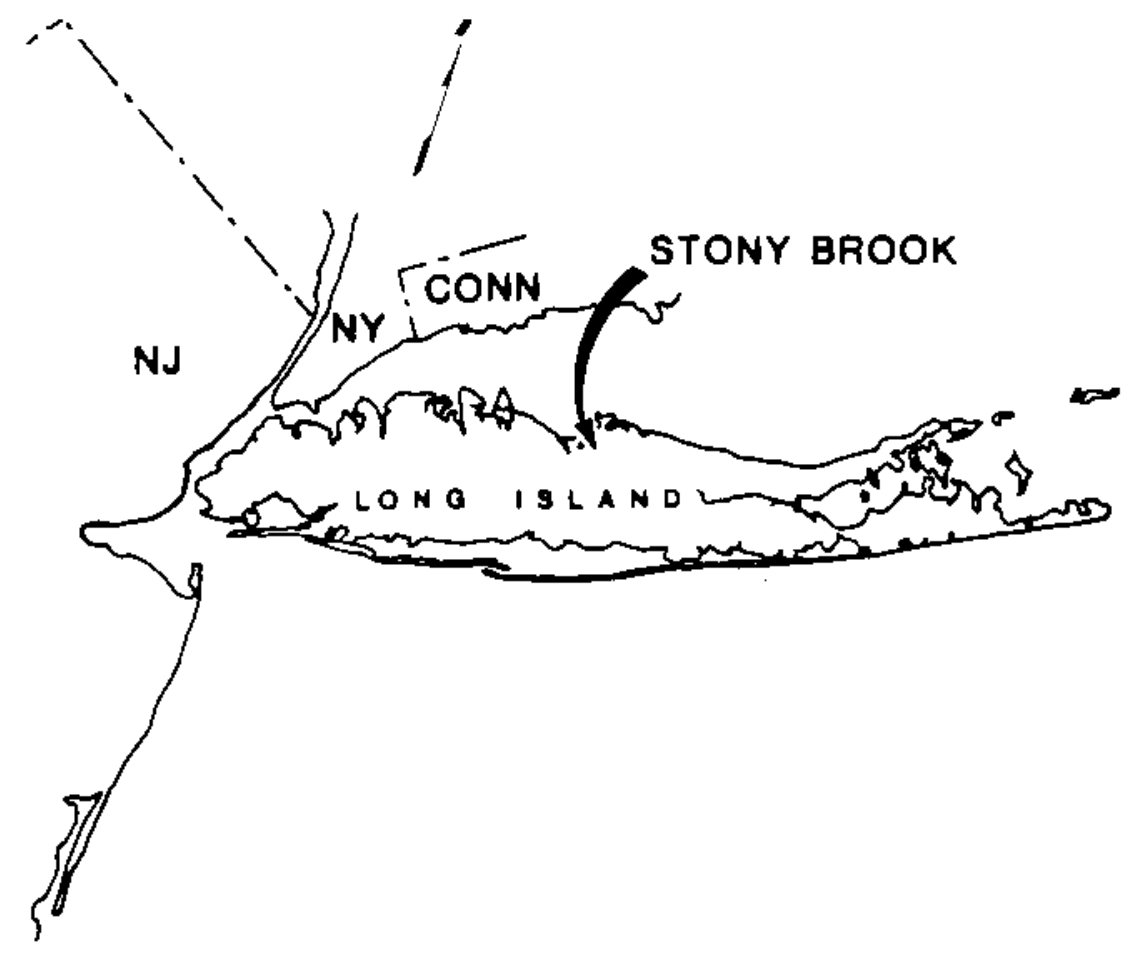

FIGURE 8. Location of Stony Brook Project 

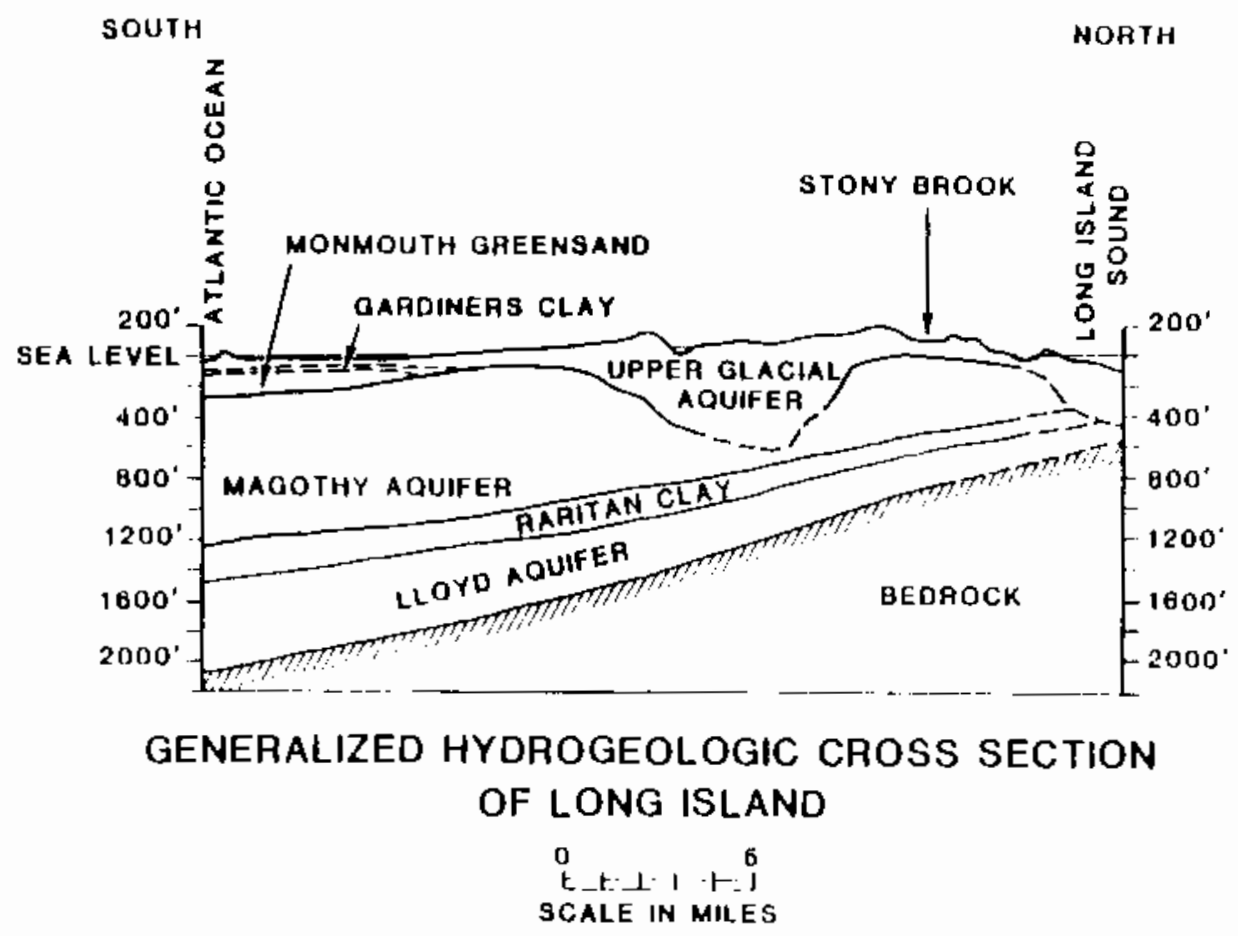

FIGURE 9. Generalized Hydrologic Cross Section of Long Is land

The physical, thermal, and chemical properties of the aquifer used for chill storage, and the adjacent confining zones were characterized by field testing and by a two-dimensional finite element computer model.

The ATES concept was to pump water from one set of wells, chill it in winter with a cooling tower and inject it back into the ground through injection wells separated from the pumping wells. During summer, the well functions would be reversed. Pumping wells would become injection wells and injection wells would become pumping wells. The cold water would be pumped out of the ground and used for air conditioning. After being heated by the air conditioning load the water would be injected into the injection wells.

The ATES chill demonstration project at Stony Brook was terminated at the end of FY 1981 due to reduction of funds in support of the STES 
Program for FY 1982. However, some follow-on work was done, under support of the New York State Energy Research and Development Agency (NYSERDA). A comprehensive cost estimate for ATES alternatives at Stony Brook (Kannberg et al. 1982) was completed. We11 restoration studies were performed to resolve well plugging concerns. The injection problem could be resolved by incorporating a filtration system or increasing the injection well diameter (Kannberg et al. 1983).

A nonisothermal chilled water injection test utilized an existing $30.5-\mathrm{cm}$ well and a 150 ton chiller. A new 15.2-cm well was installed $85 \mathrm{~m}$ from the $30.5-\mathrm{cm}$ well and screened at the same depth range as the existing $30.5-\mathrm{cm}$ well. Nine observation wells were positioned about the doublet wells to provide temperature and water-level measurements. Baseline temperature and water-level measurements were obtained, and a 48-hour pumping test was performed to determine aquifer characteristics.

To begin the chilled-water injection test, $10.6^{\circ} \mathrm{C}$ groundwater was pumped at $1136 \mathrm{\ell} / \mathrm{m}$ from the newly installed $15.2-\mathrm{cm}$ well and piped to the 150 ton chiller. The water temperature was reduced to $5.2^{\circ} \mathrm{C}$, and the water was injected into the $30.5-\mathrm{cm}$ well. Injection continued for 42 days, during which $69,000 \mathrm{k} \ell$ of chilled water were injected. Pumping rates and pumped-water temperatures were monitored. After injection, the chilled water was stored for 72 days to determine the effect of the natural hydraulic gradient on chill plume migration and to measure other thermal losses. During storage, the temperature at the center of the storage zone increased by less than $0.3^{\circ} \mathrm{C}$ (Skinner and Supkow 1982).

The recovery of chilled water was accomplished by pumping from the $30.5-\mathrm{cm}$ well and returning recovered water to the aquifer through the $15.2-\mathrm{cm}$ well. The chilled water was pumped at $1136 \mathrm{l} / \mathrm{m}$, but the reinjection well would not accept the water at this rate because of plugging early in the reinjection cycle, Ouring initial recovery, the production water gradually and uniformly increased in temperature. Toward the end of the recovery period, the production water temperature began to asymptotically approach the aquifer ambient temperature. 
Analysis of energy recovery from the chill injection test was based on the temperature versus time relationship of the water recovered while pumping a volume of water equal to the volume injected. Temperatures in observation wells at the end of the recovery period indicated that, compared to baseline measurements, only a small amount of residual chill remained in the aquifer (Kannberg et al. 1983). In evaluating recovery efficiency, two approaches were taken. First, total chill energy recovered was compared with total chill energy injected. Second, usable chill energy recovered was compared with total chill energy injected. The first value is a measure of general aquifer efficiency of storage and recovery. The second value is germane to applications in air conditioning where there is an upper temperature limit (the cutoff temperature) for cooling water that can be used in air conditioning systems. The actual efficiency of recovery is based upon the percentage of chill recovered at or below the cutoff temperature.

Chill energy recovery in terms of total chill energy injected was approximately $60 \%$. With a $1.67^{\circ} \mathrm{C}$ temperature rise cutoff, chill energy recovery was only $30 \%$. Numerical simulation of recovery, in which the groundwater flow was normalized (by adding wells and pumps designed to extract groundwater up-gradient and inject water down-gradient), indicated that total efficiency could be increased to more than $80 \%$.

Aquifer characterization studies included exploratory driliting, geophysical logging, pump testing, and computer simulation (Supkow and Skinner 1981). The occurrence and movenent of groundwater within the geologic regime is the result of hydrologic balance between local rainfall and discharge through the sediments to the Atlantic Ocean.

Stony Brook 1jes $2.4 \mathrm{~km}$ north of the groundwater divide. Because the deeper aquifer sediments do not outcrop on the island and the island is surrounded by seawater, the only freshwater source in deeper aquifers is recharge from overlying aquifers. At Stony Brook groundwater flows downward from the Upper Glacial aquifer to the underlying upper Magothy aquifer. The Upper Magothy consists of highly discontinuous, thinly bedded sediments of variabie thickness; specific beds often cover areas with mean diameters of only 100 to $200 \mathrm{~m}$. 
Ideal aquifer storage requires confining layers above and below the reservoir. Although Stony Brook does not have well defined confining layers, the results of the doublet test indicate that the injected chilled water was probably confined, not by continuous individual confining layers, but rather by composite strata consisting of thinly bedded, less permeable horizontal laminae. These laminae occur throughout the formation. Generally, the zones of more-prevalent, interbedded, less permeable clayey silts are less than $0.9 \mathrm{~m}$ thick, with many zones less than $0.3 \mathrm{~m}$ thick. At the test site, no correlation could be made between zone thickness and lateral continuity. Individual zones are composed of an alternating thinly bedded sequence of 1) fine to coarse sand with minor silt and 2) silt to silty clay with minor sand.

Because there are no well defined confining zones in the aquifer flow system beneath Stony Brook, the hydraulic conductivity across individual laminae is less significant than is the cumulative effect of zones of laminae in confining injected chilled water. The average horizontal hydraulic conductivity is about 100 times the vertical hydraulic conductivity. Low vertical hydraulic conductivity was detected within the confining zones both above and below the chill storage zone.

The measured transmissivity was 437 to $920 \mathrm{~m}^{2}$ per day. Variations occurred laterally from well to well. Modeling of the doublet test used the transmissivity value of $465 \mathrm{~m}^{2}$ per day. Measurements of water levels and temperatures suggest a narrow zone of relatively high transmissivities within the test area. This result is consistent with the depositional environment in which the aquifer developed (i.e., stream channel deposition, over-bank sedimentation, and swamp settling, all of which would produce variable hydraulic conductivity, both vertically and horizontally).

Natural groundwater flow rates and directions are very important in an ATES system, because a relatively high velocity will cause stored water to drift excessively. The aquifer permeability, based upon a uniform aquifer thickness of $17 \mathrm{~m}$ used in the numerical simulation and a transmissivity of $465 \mathrm{~m}^{2}$ per day, was about $27 \mathrm{~m}$ per day. With an average hydraulic gradient of 0.00334 , the average Darcy velocity was estimated to 
be $0.09 \mathrm{~m}$ per day. With an effective porosity of 0.25 , the average pore velocity was estimated to be $0.37 \mathrm{~m}$ per day. The velocity of the chill plume movement during the chill storage period was estimated at $0.18 \mathrm{~m}$ per day.

Baseline temperature measurements revealed an unusual reverse therma] gradient in the upper $120 \mathrm{~m}$ of sediments at Stony Brook. This may have been caused by the earlier injection of warm water discharged from air conditioning systems, previously used on campus. Some of the extraneous heat may have leaked from the $177^{\circ} \mathrm{C}$ hot water main. In a natural environment, groundwater generally becomes warmer with depth because of the upward heat flow from the interior of the earth. At Stony Brook the temperature was found to decrease with depth, at least to about $122 \mathrm{~m}$, the maximum depth of the observation wells.

A computer numerical model (GREASE-2) of the Upper Magothy at Stony Brook was prepared to simulate aquifer response to thermal energy storage. Initial simulations of the doublet test were performed with regional data to predict aquifer response. The numerical model was then calibrated with isothermal pumping test data and verifjed with nonisothermal doublet test data so the simulations more closely matched the observed performance. This model could then be used to predict aquifer performance and recovery efficiency in the Magothy aquifer for various conceptual designs with reasonable confidence.

\subsubsection{Tuscaloosa, Alabama, Field Experiment}

An ATES chill system was incorporated into the $60,000-\mathrm{ft}^{2}$ Parisian Department Store in Tuscaloosa, Alabama, and became operational in Fall 1981. It is estimated that aquifer storage can save an appreciable percentage of summer chilling costs. The ATES chilling system is backed up with a conventional cooling system with maximum capacity of 200 tons. (Schaetzle et al. 1981; Kannberg et al. 1982). The system uses two adjacent cold wells, two adjacent warm wells, a cooling tower, sand filter, and cooling coils.

Cold water for air conditioning is withdrawn from the cold wells and passed directly through water-to-air cooling coils. The water is injected 
into the warm wells. The cooling coils at both locations have eight rows and eight fins per inch. All heat exchange is by counterflow. Because water makes only one pass per year, temperature differences of $9^{\circ} \mathrm{C}$ and greater are recorded. The coils have performed better than expected, with exit water temperatures approaching $2^{\circ} \mathrm{C}$ of entering air temperature. Water chilling occurs in a 400-ton cooling tower with 50-hp centrifugal blowers to inject air. Water is chilled at a constant flow rate whenever the wet-bulb temperature drops below $10^{\circ} \mathrm{C}$. At temperatures near and below freezing, vanes to the blowers close to maintain water temperature above $0^{\circ} \mathrm{C}$.

The water is passed through a sand filter to prevent the addition of pollutants to the aquifer. The water is exposed to the atmosphere only in the cooling tower. The aquifer is unconfined and consists of alluvial and terrace deposits of the nearby Black Warrior River. These deposits lie directly on the Pottsville formation of Pennsylvanian age. The aquifer is approximately $12 \mathrm{~m}$ thick and consists of very porous sands and gravels. The Parisian wells are $24 \mathrm{~m}$ deep with 15.2-cm PVC casing and sand screen, and are packed with sized gravel. It is critical that siot size in the screens and packing design be calculated to exclude the fine grain sizes in the reservoir formation. At Parisian the wells permitted fine sand to pass through the packing during withdrawal and through the slots into the welibore, creating an accumulation of fine sand in the cooling tower or in the opposite injection wells, depending on which way the water was being pumped. This fine sand accumulation necessitates flushing out the injection wells and cleaning out the cooling tower periodically. It is recommended that automatic backfiushing of wells (perhaps on a daily basis) be built into the system. It is also recommended that water be filtered in both directions.

Water chilling occurred for part of the 1981-82 winter. During Summer $1982,18.3^{\circ}$ to $19.4^{\circ} \mathrm{C}$ water was used to supplement the air conditioning. Basic summer data to carry part of the air conditioning load are: water volume transferred--56,790 k\& $\left(15 \times 10^{6}\right.$ ga 1$)$, air conditioning energy--646 $\times 10^{6} \mathrm{~kJ}\left(612 \times 10^{6}\right.$ Btu $)$, power input-- $73 \times 10^{6}$ 
kJ $\left(69.5 \times 10^{6} \mathrm{Btu}\right)$, and coefficient performance--8.81. A total baseload of 50 tons of air conditioning was supplied for this period.

\subsection{LABORATORY STUDIES}

Permeability reduction and material compaction studies have been performed at PNL on some generic reservoir materials: Massition sandstone, Ottawa silica sand, and a simulated sand pack with both of these materials (Kannberg et a]. 1982). Laboratory testing of core was performed at in situ pressure, with steady-state liquid flow, and at room and elevated temperature. Three major test types were performed: 1) flow with temperature variation to establish baseline permeability data, and to help establish the magnitude and nature of flow- and temperature-induced permeability-reduction mechanisms; 2) flow with repeated cycles of heating and cooling to help establish the magnitude and nature of permeabilityreduction mechanisms induced by thermal fatigue; and 3) simulated injection in sand-pack samples to establish the magnitude and nature of permeability-reduction mechanisms induced by injection or temperature. Massilion sandstone generaliy showed a permeability vaiue at $150^{\circ} \mathrm{C}$ averaging about $60 \%$ of its room temperature value. Ottawa silica sand generally showed a permeability value at $150^{\circ} \mathrm{C}$ averaging about $65 \%$ of its room temperature value. And sand-pack specimens generally showed a value at $150^{\circ} \mathrm{C}$ averaging about $50 \%$ of their room temperature values.

After cooling from $150^{\circ} \mathrm{C}$, Massillon sandstone showed a permanent permeability reduction to about 88 to $60 \%$ of the starting value, while ottawa silica sand showed essentially complete recovery of permeability. Sand-pack specimens exhibited greater permanent permeability reduction to about $70 \%$ of the starting value. Permeability impairment in the sand pack specimens was both time- and temperature-dependent.

Repeated heating and cooling cycles did not induce significant permanent permeability reduction. After four thermal cycles, sandstone permeability was approximately $80 \%$ of its starting value, while silica sand was essentialiy unaffected. 
In conclusion, permeability impairment was shown to be both temperature- and time-dependent in the generic reservoir materials and in the sand-pack samples. Repeated heating and cooling cycles did not result in large-scale cumulative impairment of permeability in either Massillon sandstone or Ottawa silica sand. Simulated injection in the sand-pack samples was shown to result in some time-dependent permanent impairment but essentially no permanent, temperature-induced impairment. Sources of permanent permeability impairment (plugging) were found; they were small amounts of corrosion products formed in the test apparatus flow loop, internal fines from the samples, and particulates produced by the mechanical breakdown of the sand-sandstone interface in the sand-pack samples.

Laboratory tests to measure the effect of temperature on the permeability of sandstone core from the St. Paul site were also conducted at PNL (Blair and Deutsch 1983). These tests used a state-of-the-art rock mechanics device designed especially for testing aquifer materials (Blair and Stottlemyre 1981). Core samples were tested at a confining pressure, pore pressure, and flow rate equivalent to conditions in the injection zone near the test well at the St. Paul FTF. Data from these tests indicate that 1) permeability remained constant from 25 to $150^{\circ} \mathrm{C}$ and 2) permeability increased under reversed flow. Initial interpretation is that migration of internal fines was the major physicochemical process affecting permeability for these tests. These results are significant for the development of STES because they represent some of the first laboratory evidence that increasing temperature may not degrade the permeability of aquifer formations.

\subsection{NUMERICAL MODELING}

Numerical modeling of ATES behavior is underway at numerous locations. Many models have the capability to simulate ATES performance within reasonable assumed limits of geologic aquifer characteristics (Mercer et al. 1981). The specific objective is to predict the injection, storage, and retrieval of thermal energy resources within the groundwater environment. 
The PT model (formerly called CCC) was developed by Lawrence Berkeiey Laboratory (LBL) and consists of a one-, two- (planar and axisymmetric), or three-dimensional integrated finite-difference model that simulates transient pressure and temperature fields (Tsang, Buscheck and Doughty $1981 \mathrm{a}, \mathrm{b})$. This is the most thoroughiy tested multidimensional ATES model. The PT model has been used extensively to simulate testing at the Mobile Field Test Facility for both the first $\left(58^{\circ} \mathrm{C}\right)$ and second $\left(82^{\circ} \mathrm{C}\right)$ cycle tests. The model was calibrated and verified by utilizing Mobile site data; subsequently minor modifications to the model were based on refined geohydrologic data.

The model-predicted temperature curves for recovered water, as well as the total energy recovery factor (efficiency), showed excellent agreement with the field-measured results for both tests. The temperature-time curves were within a few degrees of the measured values for all points. Predicted and measured subsurface temperatures also showed agreement, as indicated in Figure 10 (Tsang, Buscheck, and Doughty 1981b). The model-predicted energy recovery factor for the first cycle test was 0.620 compared with the measured value of 0.552 . Slight modification of the model parameters revised the predicted recovery to 0.585 . The model-predicted energy recovery factor was 0.434 for the second cycle test, and the measured value was 0.452 .

The successful prediction of the first and second cycle test values at the Mobile FTF shows the applicability and value of numerical modeling technology to ATES problems involving complex geohydrologic regimes.

A]ternative injection and production schemes were studied to maximize the recovery factor for a 3-month cycle with a constant injection flow rate of $424 \mathrm{~s} / \mathrm{min}(112 \mathrm{gpm})$ and temperature of $82^{\circ} \mathrm{C}$. The knowledge that buoyancy flow is strong was gained from the first- and second-cycle simulations, so three approaches were taken. Shown schematically in Figure 11, the approaches were:

1. Simply inject into and produce from the upper portion of the aquifer where most of the hot water would naturaliy flow because of buoyancy effects (labeled $U$ ). 


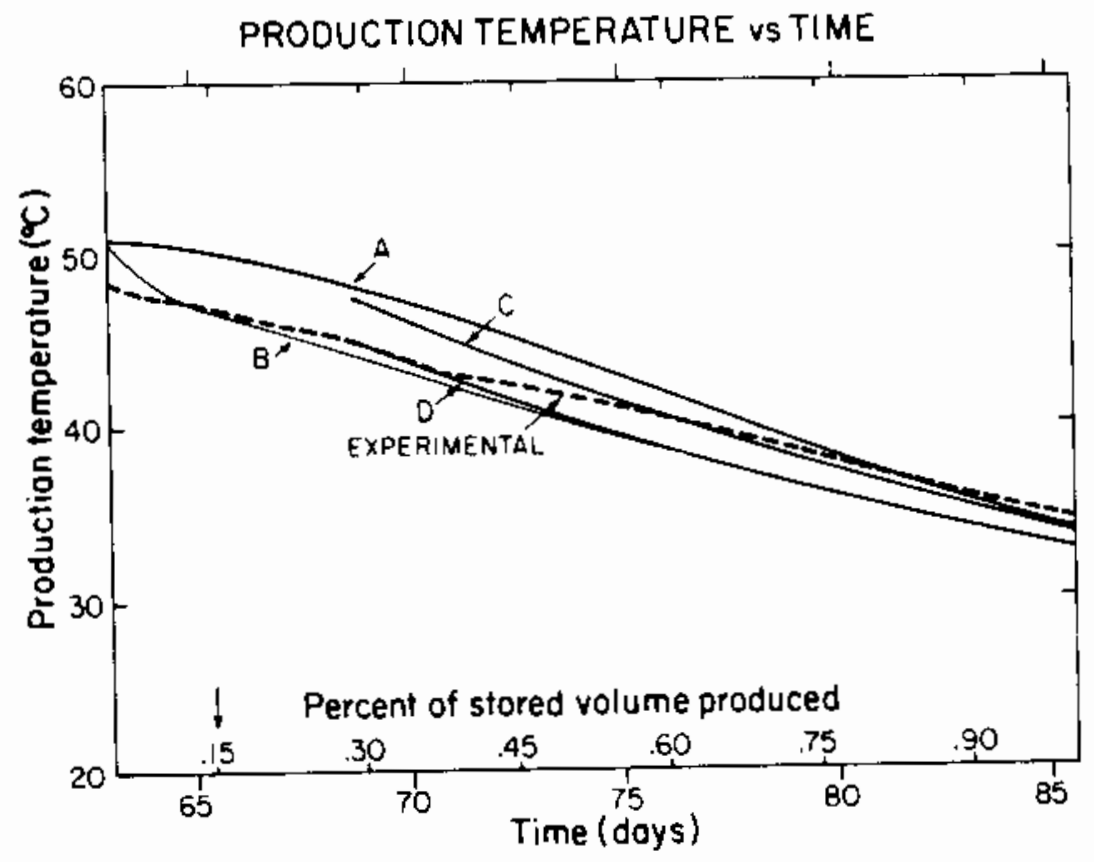

FIGURE 10. 1981 Mobile Experiment First Cycle Production Temperature as a Function of Time. Note: Curve A--basic numerical simulation, Curve B--aquifer permeability increased from 63 to 94 darcys, Curve C--three-layered permeability model, Curve D--large thermal dispersion effect included.

2. Attempt to maintain a compact shape for the injected fluid. Buoyancy flow is counteracted by pumping from the bottom of the aquifer as hot water is injected into the top (1abeled $S$ ).

3. Inject into the upper portion of the aquifer. Then, while producing from the upper portion, produce (and discard) colder water from the lower portion of the aquifer. Thus, the colder water will not be pulled into the upper well where it would iower production temperature (labeled $M$ ).

For reference, Figure 11 also depicts an approach using full penetration during injection and production. For a cycle consisting of 1 month each of injection, storage, and production, the maximum recovery 


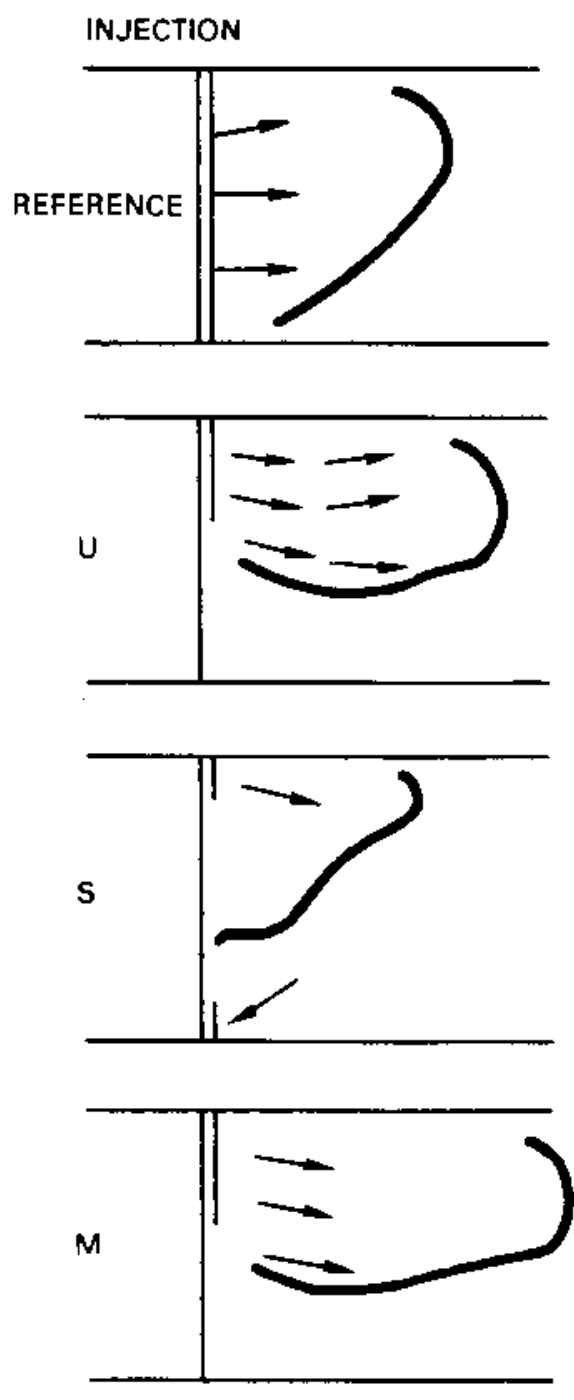

WITHDRAWAL
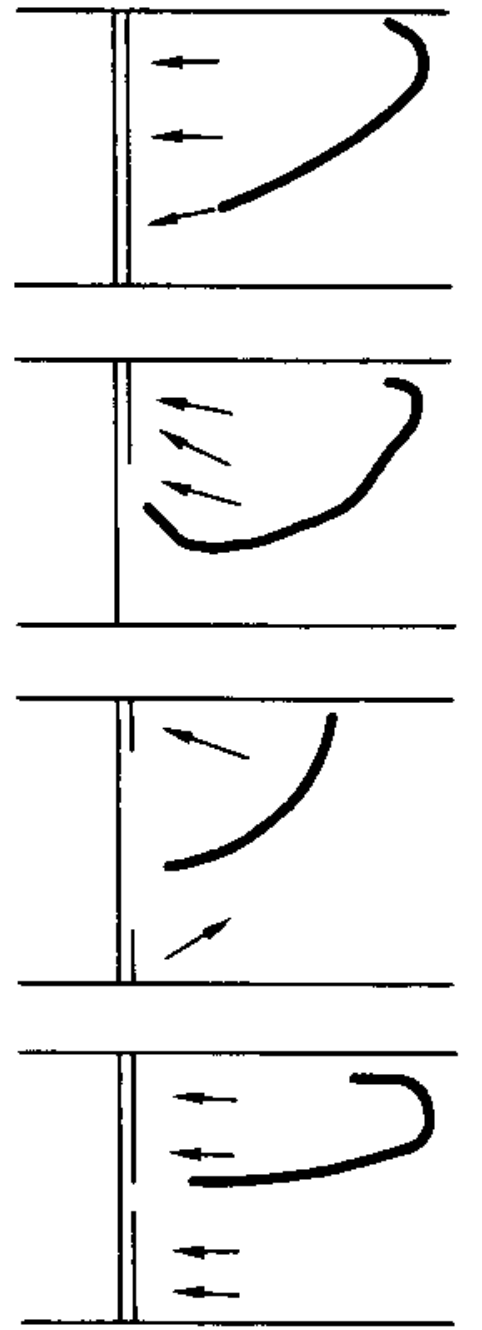

FIGURE 11. Injection Scenarios Modeled 
factor is approximately 0.52 , representing an improvement of roughly 0.12 over the reference case. However, if the 3-month cycle is altered so that 2 months of injection are followed immediately by 1 month of production (at twice the injection flow rate, thereby doubling the storage volume), a recovery factor of approximately 0.66 is possible. Hence, for this system, the volume of fluid injected is as important as the manner in which it is injected and produced.

The successful prediction of the first- and second-cycle energy recovery factors demonstrated that the main physical processes occurring in the Mobile ATES field experiment are probably well understood and can be properly simulated by the numerical model PT. These third-cycle design studies consider a substantial number of alternative injection/production schemes.

Aquifer characterization at the St. Paul FTF also included numerical modeling (Kannberg et al. 1983). A two-dimensional radial flow model was constructed and calibrated with the data from a 4.5-day pump test. Areal anisotropy within the aquifer accounted for small but significant deviations of the modeled results from the drawdown data. A conclusion of that modeling study was that a three-dimensional model would more accurately represent the aquifer system. Analysis of aquifer-test data indicated that the Franconia-Ironton-Galesville aquifer is really anisotropic with principal axes of transmissivity not paraliel to the well doublet as was assumed in the U.S. Geological Survey SWIP code, a finite difference model. The well doublet is at an angle of approximately $30^{\circ}$ to the major axes of transmissivity for both parts of the aquifer. Therefore, a three-dimension groundwater flow model was constructed of the Franconia-Ironton-Galesville aquifer and calibrated with data from the same test. Aquifer transmissivity simulated by the model was $944 \mathrm{ft}^{2} /$ day $\left(87.7 \mathrm{~m}^{2} /\right.$ day $)$, well inside the range of 900 to $1050 \mathrm{ft}^{2} /$ day $(83.6$ to 97.6 $\mathrm{m}^{2} /$ day) calculated from field test data.

Other aquifer models include CFEST, SFM, and AFM. CFEST, developed by Pacific Northwest Laboratory, is a vertical piane, horizontal plane, axisymmetric or fully three-dimension finite-element numerical model of 
heat, fluid, and solute flow in a confined aquifer (Kannberg et al. 1982). The code has been extensively used for chemical transport simulation. SFM was developed by Lund Institute of Technology (Lund, Sweden) and Lawrence Berkeley Laboratory. SFM utilizes an axisymmetric mesh consisting of cells that represent equal volumes and through which, under steady flow, fiuid travels in a uniform time increment (Kannberg et al. 1982). Conduction is modeled with explicit finite-difference methods, whereas convection is addressed by computation of the bulk fiuid motion. AFM, developed by Pacific Northwest Laboratory, is a modified version of SFM that permits simulation of ATES multiple injection/withdrawal wells and regional flow (Kannberg et a1. 1983).

\subsection{APPLICABILITY}

The applicability of aquifer thermal energy storage to a given region is determined by five conditions: 1) an available source of thermal energy or chill, 2) a technicaliy feasible aquifer reservoir, 3) a market for the recovered energy or chili, 4) compatibility between energy storage and utilization, and 5) economic competitiveness with alternative energy supplies. These conditions are very location-specific and, except for item 2), time-specific.

The available source of thermal energy would be 1) surplus heat from combustion, nuclear fission, or solar radiation or 2) heat cogenerated from combustion. The available source of chill would be atmospheric cold. Therefore, aquifer thermal energy storage of hot water would require proximity to an electrical generating or industrial plant. Aquifer thermal energy storage of chilled water would require location within a region subject to annual prolonged subfreezing periods. However, the cold storage facility need not be close to an electrical generating plant.

Technically feasible aquifers are those that meet certain design requirements: 1) large volumes (e.g., on the order of $10^{7} \mathrm{kl}$ ), 2) low thermal conductivities of overlying and underlying strata, 3) sufficiently high transmissivity to accept high input and supply high output rates, 4) fluid migration rates from convection and advection 
sufficiently low to maximize thermal containment and recovery efficiency, 5) discovery water pressure sufficient to store thermally conditioned water, 6) geographic proximity to energy supply and consumption points, and 7) environmental acceptability.

A market for the recovered energy or chill consists of residential, commercial, institutional, or industrial users. Normally, district heating or cooling is the projected market. Process hot water for such an industry as food processing is also in prospect.

Compatibility between energy storage and utilization simply means that supply and demand are out-of-phase (i.e., cyclical, diurnal, seasona 7 ).

Economic competitiveness with alternative energy supplies may be the most difficult criterion based upon recent experiences with gyrating crude petroleum prices and regional forecasts of electrical power demand, especialiy in the northwestern U.S.

On the basis of known aquifer geology and hydrology, climate, current population distributions and trends, and generally escalating energy costs, the following U.S. Geological Survey water-resources regions are candidates for selected exploration and development of aquifer thermal energy storage:

- Arkansas-White-Red

- California

- Great Lakes

- Lower Mississippi

- Mid-Atlantic

- Missouri Basin

- Ohio

- Souris-Red-Rainy

- South-Atlantic Guif

- Tennessee

- Texas-Gulf

- Upper Mississippi. 


\subsection{COMPARISON WITH OTHER STORAGE TECHNOLOGIES}

Aquifer thermal energy storage is only one of many seasonal storage concepts under investigation. Under certain conditions ATES appears to be competitive with, and probably superior to, other modes of long-term thermal storage. The merits of ATES are identified below (Reilly, Brown and Huber 1981a).

- Storage costs are not directly related to the total amount of energy stored because use of the aquifer is essentially free. Rather, storage costs are proportional to the rate of energy storage or retrieval. The rate of water injection and withdrawal determines the number of wells, and well-related costs constitute the largest portion of the capital cost for a typical ATES installation.

- Energy is stored as heat or chill. Most waste energy and energies of opportunity exist in this same form of thermal energy, and many of the ultimate uses for the stored energy are in the form of heat or chill. Avoiding a transformation between energy forms (such as from thermal to electrical and back to thermal) eliminates the losses inherent in such transformations.

- Water is an inexpensive, widely available storage medium with a very high heat capacity. It is safe, and the technologies for its control are well developed.

- The water is not consumed by the storage process, but instead is avaitabie for continuous cycling (or for other uses).

- Aquifers provide natural thermal insulation.

- Aquifers provide safe containment for high-temperature, pressurized water.

- Aquifers are readily available in most of the U.S.

- Short-term storage cycles may be readily superimposed upon the Ionger seasonal cycle. This characteristic makes ATES very flexible and suitable for a wide range of applications. 


\subsection{ALTERNATIVE STES TECHNOLOGY}

Although aquifer thermal energy storage (ATES) is predicted to be the most cost-effective technology for seasonal storage of low-grade thermal energy, suitable aquifers underlie only about $60 \%$ of the U.S. Therefore, other methods of STES will be required where aquifer storage is not technically or economically feasible. Alternative STES systems under consideration include pond, Take, cavern, tank, wet earth, rock, and ice thermal storage (Kannberg et al. 1982).

The main activity in alternative STES technology has been to survey and evaiuate nonaquifer STES concepts. The most promising concepts use temperatures below $95^{\circ} \mathrm{C}$, low-cost storage media (water and rock), construction with earth, good insulation, impervious liners, and economies of large scale (Blahnik 1980).

Except for ice storage, these concepts are based upon use of sensible heat. Other latent heat concepts and thermochemical concepts are relatively undeveloped and high in cost for seasonal storage. Currently the only thermochemical concept that might be considered is the sulfuric acid/water chemical heat pump. Another latent heat concept for potential consideration uses low-cost salt hydrates such as Glauber's salt (Kannberg et al. 1982).

\subsection{DESCRIPTION OF ALTERNATIVE CONCEPTS}

This section discusses eight nonaquifer STES concepts. All concepts can have design variations because of wide ranges in site characteristics, climates, and markets (Blahnik 1981).

\subsubsection{Ponds}

Ponds are engineered to be leak-tight and well insulated, as shown in Figure 12. Ponds must be specially designed for each site. The basic pond is a depression scooped out of the earth and filled with water. The excavated earth provides an embankment that increases the pond capacity. The sides and bottom are covered with an impermeable liner. The top of the pond is covered with insulation; in some cases, the sides and bottom 
are also insulated. The pond cover reduces thermal losses from both convection and evaporation. Complete excavation is required where the land is level.

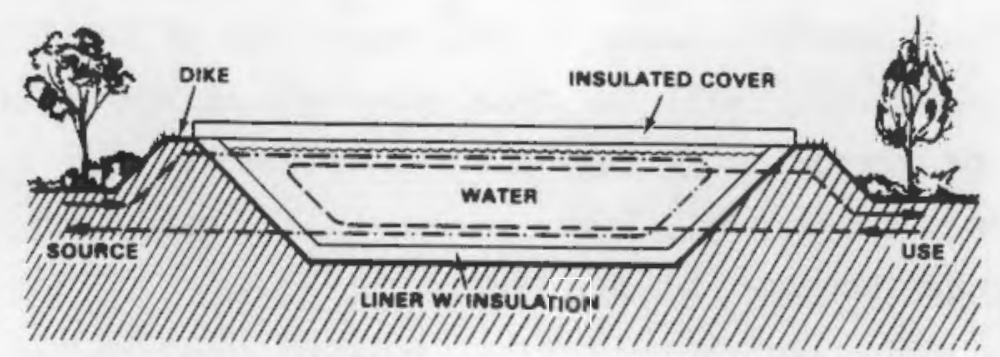

\section{FIGURE 12. Pond Seasonal Thermal Energy Storage}

Alternative designs, where less excavation is required, include the use of a dammed-up natural valley or of abandoned open-pit mines. Ponds filled with rocks can serve as artifical aquifers. Ponds can be made in rock by blasting the rock and filling the in situ rock fractures with water. Ponds can be covered with a solar collector system to provide an energy source. A solar pond over a conventional thermal energy storage pond and separated by an insulated membrane may have promise as a hybrid concept.

Pond technology has been established by many years of constructing municipal ponds, cooling ponds, etc. A principal need for pond STES is to develop a $10 \mathrm{w}$-cost liner that will last more than 20 years at up to $100^{\circ} \mathrm{C}$. The main area of concern for the liner is to have adequate shear strength on sloping regions of the pond. Lining materials that are sprayed on rock or mixed with soil should be investigated. Development of insulation that can be placed in direct contact with soil or water without absorbing moisture is also needed. A method to seal or integrally line the insulation might reduce the requirement for a separate liner. Technology advancements that reduce pond construction costs would improve prospects.

Numerous sites are available for constructing ponds in diverse regions. The market size required for heating would be equivalent to the thermal energy required to serve 100 to 10,000 homes. 
The cost of pond storage per unit can vary substantially among sites. A pond in dry, stable soil will be less expensive because of lower insulation and drainage system costs. A pond that requires full insulation will be most expensive. The cost of a pond that is constructed in a leak-tight open-pit mine would be very low because no excavation or liner would be necessary, and, perhaps insulation cost would be low. The lining and insulation usually account for a large portion of pond storage costs; if these features can be reduced or eliminated, large savings would result (Blahnik 1981).

\subsubsection{Lakes}

Lake concepts vary from small natural lakes to large dammed reservoirs and portions of large lakes or oceans. Concepts studied have included lakes sized to serve from several hundred to more than one million people.

The basic lake concept, shown in Figure 13, comprises an insulated floating cover with breakwater and insulated side panels anchored to the bottom. Bottom barriers might be used to stabilize the store thermocline(s). A solar collector system can be added to the floating cover, as with pond storage. The lake store should be sheltered from wind, ice, and wave action. Lake storage is also site-specific, but some of the construction materials (e.g., floating cover and side panels) could be standardized. Potential hybrid systems include a lake coupled with rocks, thin-walled tanks, and underwater reservoirs.

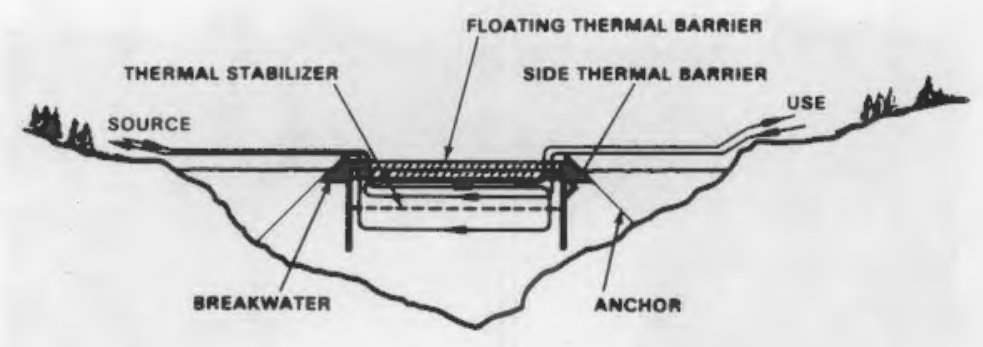

FIGURE 13. Lake Seasonal Thermal Energy Storage 
Lake STES promises very low costs and very large capacities. Lakes have the advantage of not requiring excavation, and construction with modular assemblies can be rapid and simple. Despite this concept's attractiveness, lake storage research has been limited to scoping studies, and no sizable development has commenced. Development of an insulation system that will not absorb moisture is very important to maintain good thermal effectiveness.

Sites for lake storage are likely to be limited for environmental reasons and by regulatory and alternative-use priorities. Sites at or near power plants, and where the distance to a large consumer is less than $100 \mathrm{~km}$ should be investigated. Power plants are good thermal energy sources, and their waste heat needs to be marketed. Future plants would have increased justification if they operated as both electric and thermal generation (cogeneration) facilities.

\subsubsection{Caverns}

The cavern store concept is exemplified in Figure 14. Caverns can be either natural or mined. The caverns can use in situ blasted rock to reduce excavation costs. The ideal cavern would be an abandoned near-surface mine with a height-to-width ratio of approximately one, piping possible through existing shafts, relatively easy to seal, and needing only to be filled with water. The least expensive cavern store would be more economical than a comparable aquifer store.

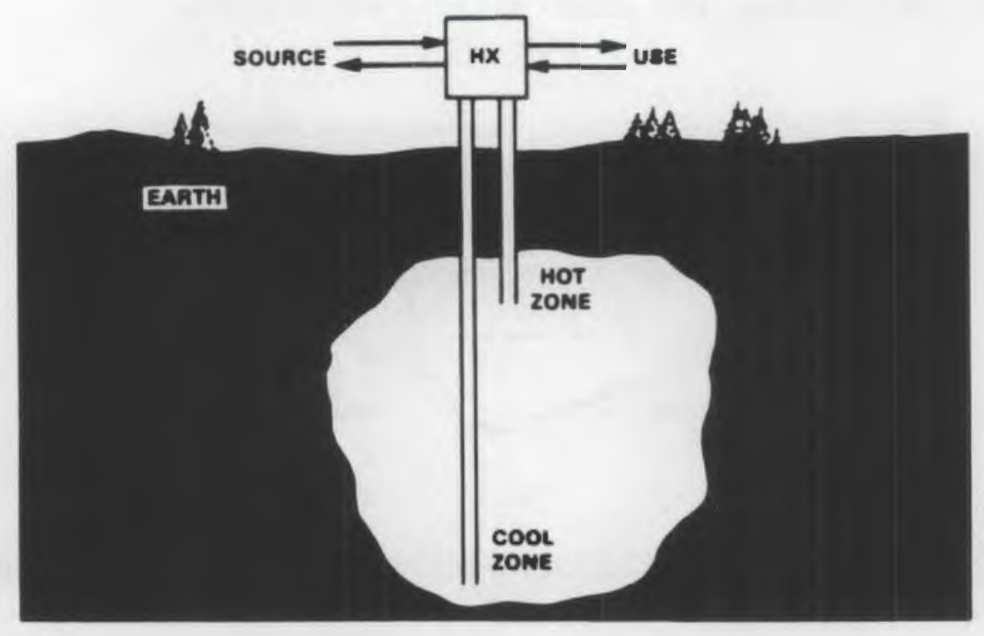

FIGURE 14. Cavern Seasonal Thermal Energy Storage 
Caverns have been used to store warm oil (to $55^{\circ} \mathrm{C}$ ) in Sweden with volumes up to two million cubic meters at a single site. A $35,000-\mathrm{m}^{3}$ development cavern for storing hot water has been constructed (Blahnik 1981). Development work is underway to determine chemical effects at higher temperatures, effects of thermal cycling, and the stability of temperature gradients. Insulation might be developed to improve operating characteristics. Development of low-cost lining methods for caverns would reduce the economic and technical risks in using this concept.

Cavern sites are limited to those locations with materials compatible with hot water and gradual thermal cycling. Caverns should serve areas needing a heating capacity equivalent to 100 to 10,000 homes. Some uninsulated caverns may need a heat pump booster because the temperature of the heat is reduced during storage.

Abandoned mine workings at Ely, Minnesota, will be characterized to determine volume available for water storage, hydraulic conductivity between shafts and slopes in the workings, and natural thermal conditions in the mine shafts (Kannberg et al. 1983). Seasonal thermal energy storage would be designed to use three distinct layers of water that are separated by sharp inverted thermoclines. These layers coincide with chemical differences that inhibit thermal convection. In Figure 15 these layers are illustrated as they occur in two mine shafts.

Based on data gathered to date, a tentative plan for developing the mines as an energy resource has been produced.

An intake pipe could be placed in a shaft to withdraw sulfate-rich water from the top of the lowest layer, just below the lower thermocline. After heat extraction by heat pump, the chilled saline water would return through a deep outlet pipe to the lowest level of the mines. As the relatively warm water is replaced by chilled waters, the deep layer of saline water would become increasingly stable and isolated from further circulation. When the effective $\Delta T$ of the deep water layer was used up, the intake and outlet pipes would be raised to the middle layer, leaving the chilled lower saline layer to accumulate geothermal heat over a period of years, thus avoiding any mixing or discharge of this water. 


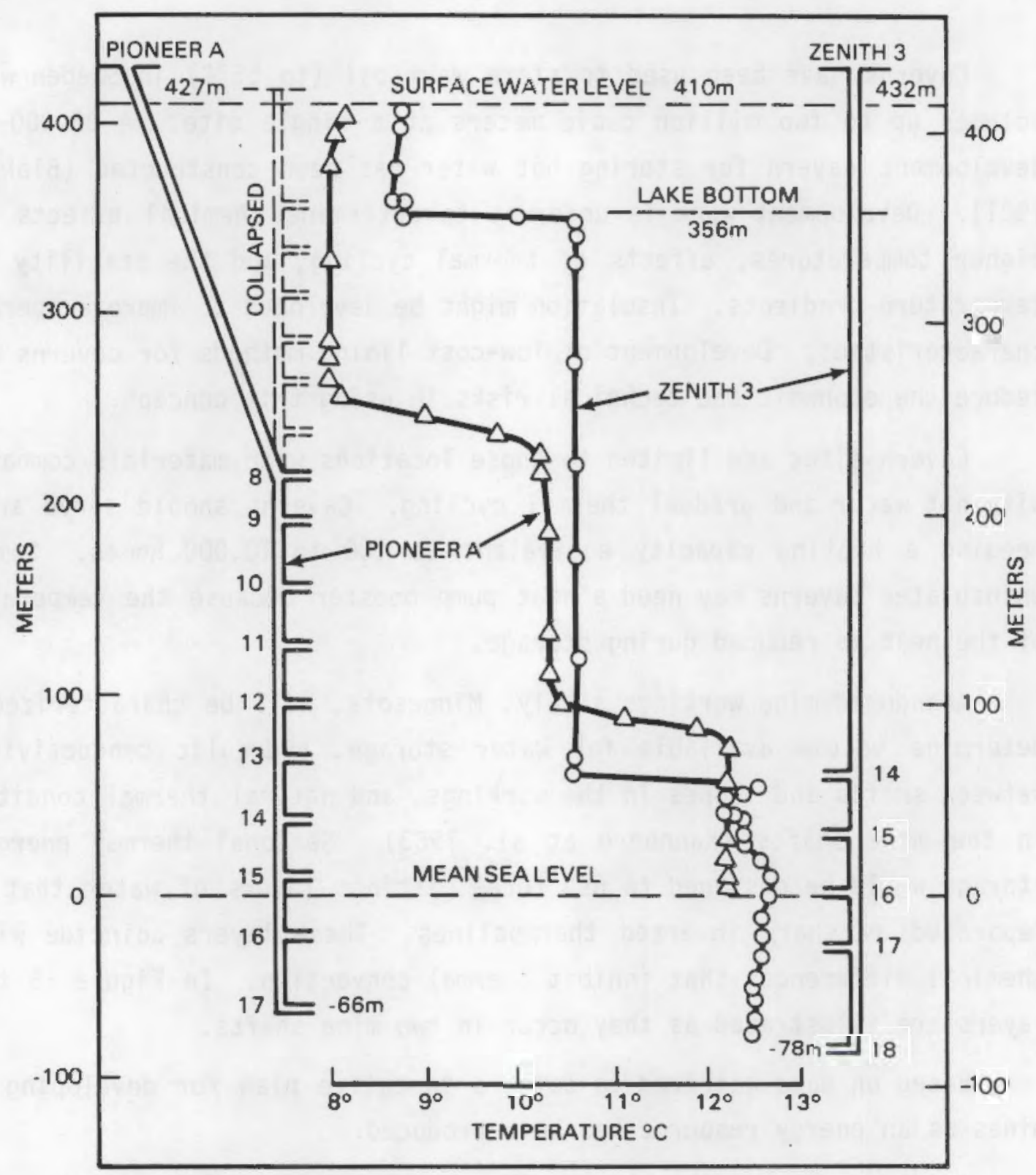

FIGURE 15. Water Temperatures in the Pioneer A and Zenith \#3 Shafts With Geometry of the Shafts and Drift Levels Shown Schematically 
A similar cycle of heat extraction and chilled water discharge would then proceed within the middle layer, but heat replenishment would be accomplished by using the lake as a seasonal solar heat collector. By early summer a surface layer of water 3 to $4 \mathrm{~m}$ deep with a temperature of $20^{\circ} \mathrm{C}$ to $23^{\circ} \mathrm{C}$ forms on the lake. A shallow intake in the lake could skim warm water and discharge it underground on the top of the water column, while chilled water from the bottom of the middle layer would be returned through an outlet pipe to the bottom of the lake. Because there is no head difference between the lake and the mine, water circulation would require little energy, and a large input of solar energy might be obtained at low cost.

This circulation scheme ultimately entails mixing relatively pure surface water with somewhat saline water from the middle layer. Although the saline water will be diluted and its alkalinity has buffering value, the effect on the quality of the net discharge from the system will need to be evaluated. Also important in evaluating environmental impacts is the very tangible positive impact of substituting seasonal solar and geothermal heat for oil heat.

\subsubsection{Tankage}

The tankage concept can take many forms. A schematic of an insulated tank is shown in Figure 16. A tank can be located aboveground or can be completely buried. The most common tanks considered for TES applications are cylindrical and constructed of steel or concrete. For large tanks, concrete is usually more economical. Tanks required for STES must be large and will usually be constructed onsite. Very large tank storage can be constructed as gravity dams with size limited only by the site and design requirements. Tanks can be lined if necessary and must be well insulated for seasonal use. Multiple tanks and tank barriers can be used to give better thermal efficiencies. Tanks may someday be used to contain phase-change and thermochemical reactive constituents for seasonal use.

Tank technology is well established and results in relatively low technical risk (Blahnik 1981). Tanks can be installed almost anywhere on 


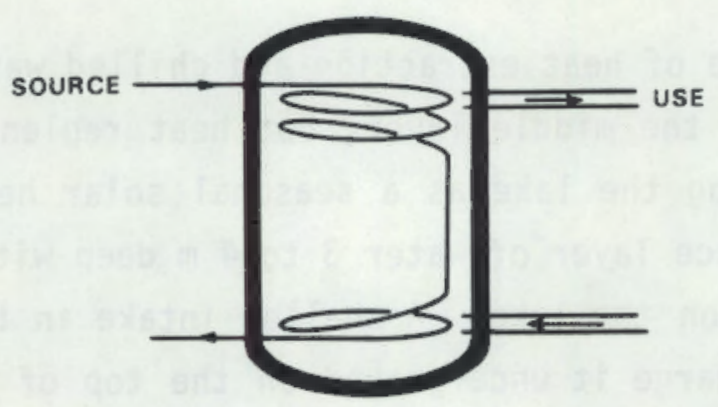

FIGURE 16. Insulated Tank Seasonal Thermal Energy Storage

stable earth. Additional development is needed for lining materials. Development of a sealed insulation that can be placed inside would also be beneficial. Structural foam insulation that can take some or perhaps atl of the loads would reduce costs of construction. Low-cost, double-walled tanks also might be a beneficial development.

Because of relatively high capital cost, tanks do not appear to be economical where a single annual thermal inventory turnover is involved (Blahnik 1981). When multiple annual inventory turnovers occur, such as with solar energy or continuous energy sources (e.g., waste heat from industrial plants), a tank may be economical. If thermal fuel costs continue to rise more rapidly than construction costs, a tank store may become justifiable for a single annual inventory turnover. Large "gravity dam tanks", artificial ponds with insulated covers, may be economical for a single annual inventory turnover.

Conventional tanks appear best suited to serve markets of 50 to 500 homes. However, large, reinforced concrete, gravity-dam tanks appear to be competitive with a market of more than 10,000 homes. Another tank concept involves small tanks stored in a large, high-density, insulated "warehouse."

The thermal effectiveness of large tanks (>100 homes) is excellent. Tanks can provide a precise thermal gradient if their height-to-diameter ratio exceeds 1. However, use of taller tanks will reduce the volume-tosurface ratio and thus offset some of the thermal stratification 
efficiency gains made with taller tanks. The storage of seasonally generated ice in large tanks combines the high density of chill energy storage with high thermal effectiveness.

Seasonal thermal energy storage in existing tanks is being investigated in the U.S. Researchers are analyzing the technical and economic feasibility of using existing underground concrete tanks in conjunction with a solar energy district heating system (Breger, McGarity and Michaels 1983). The tanks, located beneath the Charlestown Navy Yard in Boston, Massachusetts, would provide a total $5700 \mathrm{~m}^{3}$ of underground storage for the system. Results of engineering and computer analyses performed to date indicate that the retrofit application of these subsurface structures to STES would be cost-effective and technically feasible at this site in the near-term.

Areas for solar collectors are available on the flat roofs of two tall buildings in the yard. These areas should be sufficient for the system analyzed, provided most of the unusual roof structure can be eliminated. Compared to conventionally designed seasonal storage systems, these collector sites are fairly distant and elevated; thus, piping and pumping requirements and heat loss will be greater. A preferable collector site in terms of pumping and piping exists on a two-story office building just to the west of the Navy yard, although this structure is first to be renovated and plans and structural capability are uncertain.

For practical and political reasons, the National Park Service buildings around the large storage tanks are used as the heat load for the system. The buildings were determined to have an annual heat load of about $2000 \mathrm{MWh}$ and a hot water demand of 19,100 W. The buildings include apartment units, office space, room for social functions, and a museum (Kannberg 1983).

\subsubsection{Earth}

A method of using earth STES is shown in Figure 17. This concept can take on many variations in design. The heat exchange device can take many forms, such as coils, horizontal or vertical pipes, or plates. Vertical pipes and plates can be installed without excavation at some sites. "Wet 
earth" or "dry earth" STES can be used with clay, soil, sand, gravel, and other on-site materials. Earth storage can be combined with other types, such as ice, pond, and tank storage. It can be placed in covered piles (e.g., sand, overburden, excavated soil).

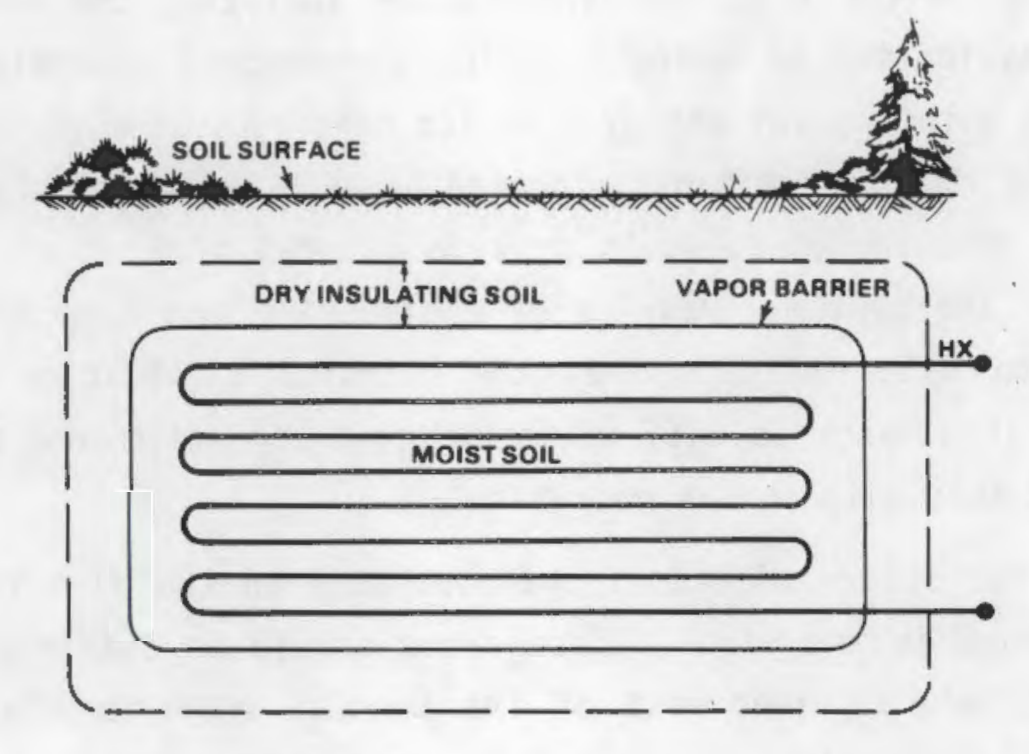

FIGURE 17. Earth Seasonal Thermal Energy Storage

Earth storage technology is being developed in Europe and the United States. The largest test demonstration is an $80,000-\mathrm{m}^{3}$ clay STES facility in Sweden (Section 5.1). Most of the stores have low temperatures, and some systems require heat pumps to raise the temperature to a useful level.

Many potential sites exist for this technology. For uninsulated stores, the market starts at about 50 homes and extends to perhaps 1,000 homes. For insulated and wet-earth stores, the market could extend down to one home when coupled with solar heat and/or a heat pump. Farms could use low-temperature heat $\left(4\right.$ to $\left.10^{\circ} \mathrm{C}\right)$ for animal shelters and thus use the earth source heat without enhancement. 
The cost of earth stores varies widely because of variations in the site conditions (stability, wetness, amount of excavation required, and others) and the different degrees to which they must be sealed and insulated. The lowest-cost systems will probably be installed with little or no excavation and some coupling with heat pumps.

The thermal effectiveness can also vary substantially. Water-saturated earth stores with good insulation can operate close to water tank performance. At the other extreme, very dry earth results in slow heat recovery at much lower temperatures and may require a temperature boost with heat pumps to be useful (Blahnik 1981).

\subsubsection{Rock}

One example of how in situ rock can be used for STES is shown in Figure 18, which illustrates a 10,000 kl demonstration facility in Sweden. Rock can be used in other forms such as underground and surface blasted rock, surface piles, trenches, etc. It can also be thermally coupled with water.

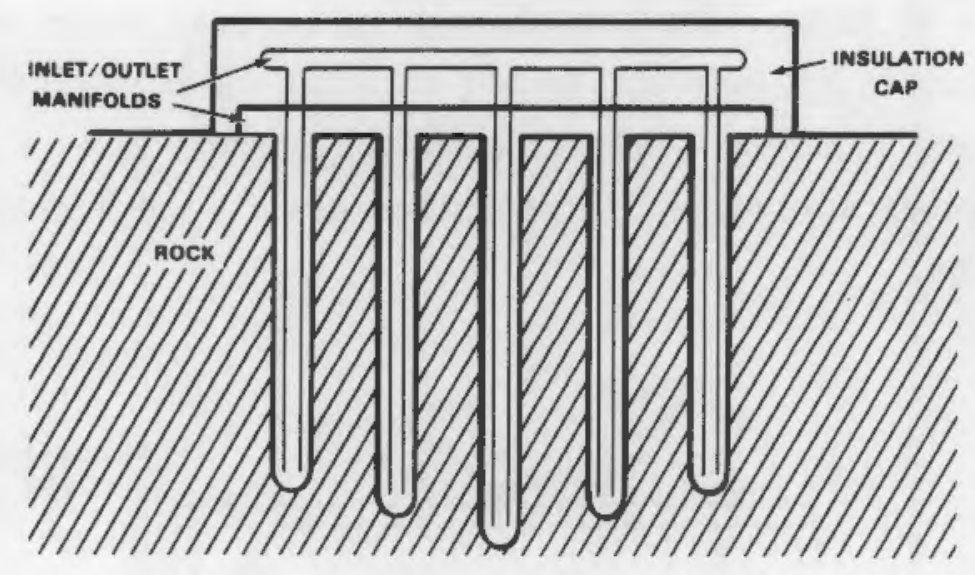

FIGURE 18. Rock Well Seasonal Thermal Energy Storage 
Less expensive drilling methods and improved lining technology would benefit this concept. Although rock fracturing from thermal cycling is a concern, it may not be as much in STES applications where only one inventory turnover occurs annually.

Rock storage should serve markets in the 100- to 1,500-home equivalent size range. The sites for use of this technology are somewhat limited to where the host rock is relatively impermeable, unfractured, and compatible with hot water.

The cost for rock well storage is very low. Rock well storage is particularly advantageous where source temperatures are low or, at the other extreme, where source temperatures are high for long periods.

Where source temperatures are low or where temperatures will degrade substantially, a heat pump system will be necessary to upgrade the heat quality. For large systems the rock will insulate well, enabling good thermal recoveries, al though usually at lower temperatures (Blahnik 1981).

\subsubsection{Ice}

Ice can be produced with heat pumps, by winter outdoor chill, or by their combined effects. One ice storage concept is shown in Figure 19. Other ice concepts include ice formed in brine tanks through outside heat exchangers, heat pipe ice bins, flooded trays and ice bins, snow-making sprinklers, water sprayed on refrigerated drums, and ice harvested from ponds and lakes.

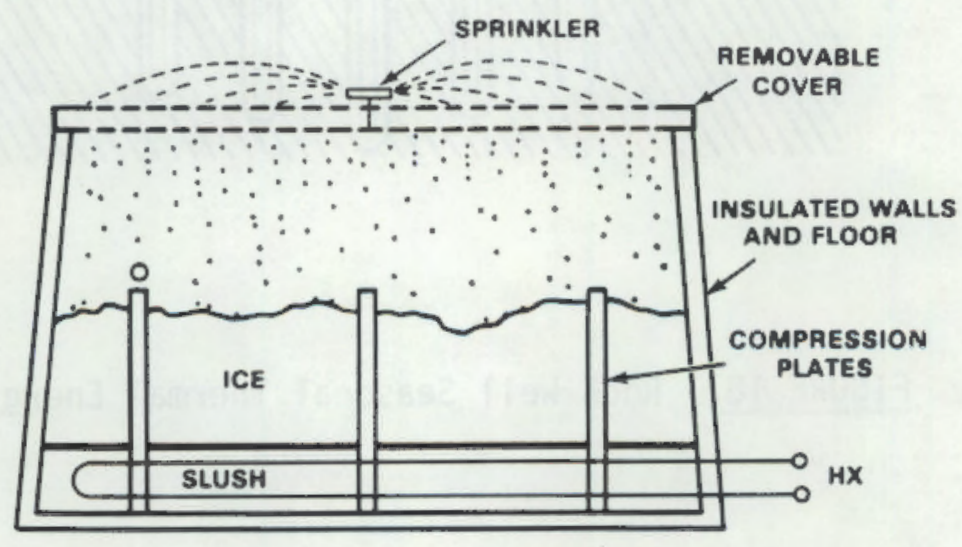

FIGURE 19. Ice Seasonal Thermal Energy Storage 
The development of ice storage is currently underway, primarily in the U.S. and Canada. Concepts using heat pipes with a tank, brine cooling tanks, snow-making machines with a pond, and flooded ice bins hold promise. The main development needs are to optimize the ice production and harvesting methods and to provide low-cost insulation and heat exchange systems. (Refer to Sections 6.2 and 6.3).

Ice storage can be used for STES where the temperatures remain below $-4^{\circ} \mathrm{C}\left(25^{\circ} \mathrm{F}\right)$ for most of the winter months. Ice can be formed at up to $1.67^{\circ} \mathrm{C}\left(35^{\circ} \mathrm{F}\right)$ through sprinkling in air and through radiation from shallow water trays to reduce temperature. Ice storage is promising for markets from a single home up to perhaps 10,000 homes. The main use will be in regions where winters get adequately cold and where significant air conditioning is required during summer months (e.g., the Great Plains of North America).

Ice has the advantage of a large heat of fusion [335J/g (144 Btu/1b)] and thus can provide cooling at a steady temperature. Ice near 100\% theoretical density requires a much smaller storage volume than water systems with equivalent cooling capacity. Also, ice can be piled high so that only the lower portion, which contains melt water, requires leak tightness and structural strength. With good insulation, the ice store can be very thermally efficient.

\subsubsection{Hybrid}

Many of the nonaquifer STES technologies and concepts can be combined to perform at an optimal level for the total system. One system that might be used for energy requirements as small as single-home units is the combination of solar energy with a tank or pond. Most other STES systems require at least 50 - to 100 -home equivalents to become thermally and economically effective. A combined solar pond and conventional pond is shown in Figure 20. A variation might include tray collectors mounted on tank roofs with a high-temperature section for absorptive air conditioning. Most crucial to achieving a market for 1 to 50 homes is the development of low-cost insulation/liner materials and low-cost construction methods, such as have occurred in the swimming pool industry (Blahnik 1981). 


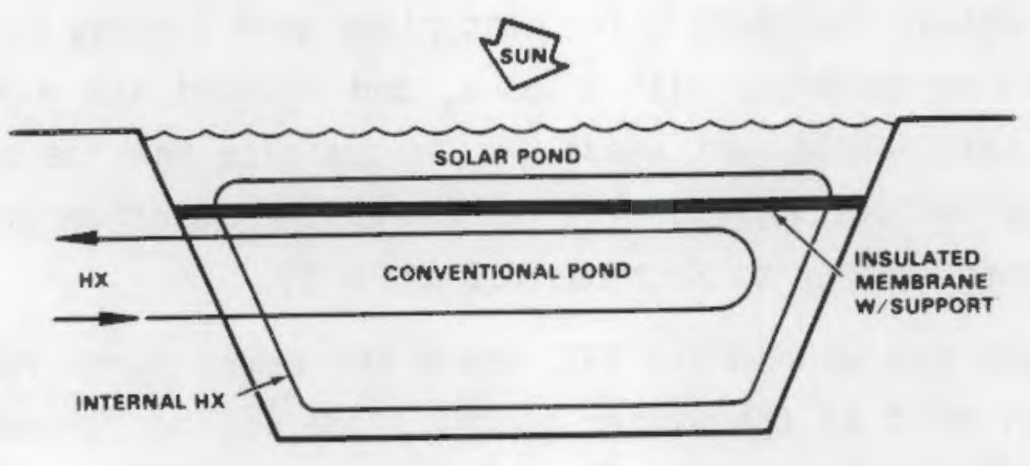

FIGURE 20. Hybrid Solar/Conventional Pond for Seasonal Thermal Energy Storage

The possible hybrid combinations are too numerous to catalog in this summary.

\subsection{TECHNOLOGY ASSESSMENT}

Comparison of seven alternate storage media or containments is shown in Table 4. In terms of the relative state of technology, tankage is excellent, and pond and ice storage are both good. Cavern and rock borehole are fair, and earth is fair-to-good. Although lake technology is poor, it could be accelerated and implemented very rapidly.

Most of the concepts need development improvements in lining and insulation for systems above $65^{\circ} \mathrm{C}$. For chill storage such as ice, existing materials are probably adequate if they can be made leak-tight. Lake storage needs more study of environmental effects. Cavern liquid chemical discontinuities and thermal cycling effects must be examined in more detail.

\subsubsection{Storage Sizing}

The approximate storage capacity ranges (in home-equivalents) required for achieving cost- and thermal-effectiveness are shown in Figure 21. The sizing is necessarily rather crude and was based generally upon costs of less than $\$ 15,000 /$ home, storage efficiencies greater than $70 \%$, and size ranges available in the literature. Generally a STES system 


\section{TABLE 4. Nonaquifer STES Concept Technology Assessment}

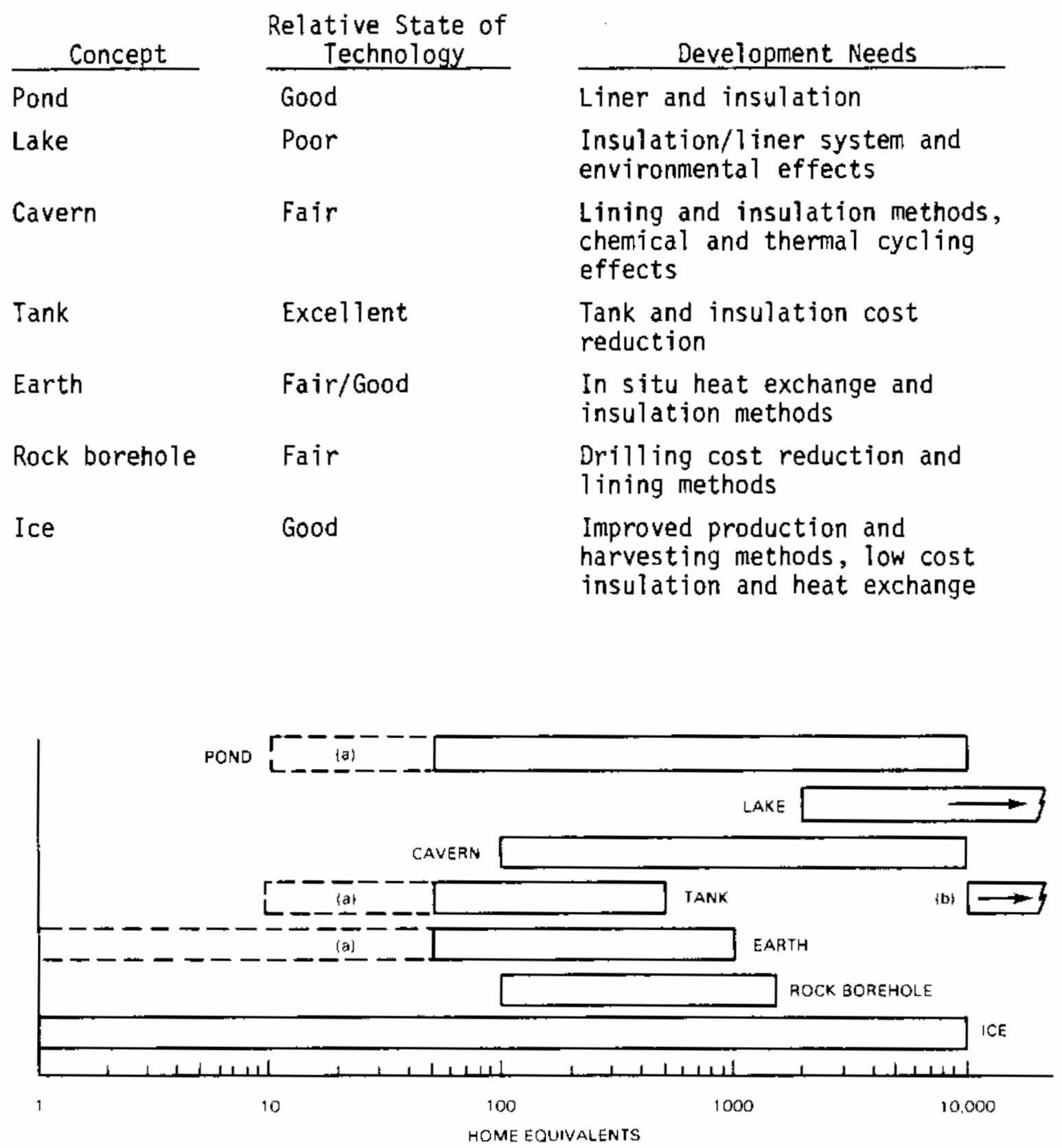

1a) AT SOME SITES

(b) WITH GRAVITY DAM TANK

FIGURE 21. Home Equivaient Capacity Required 
requires at least a home equivalent capacity of 50 homes to be feasible. Ice and earth storage can probably be used in as little as a one-home capacity at some sites, especially if heat pumps are used in tandern with thermal storage. Tankage and pond storage may also have some potential for less than 50 homes at some sites where solar heating and cooling and muttiple annual turnovers of inventory are used. A larger capacity for tanks could be realized if gravity dam tanks are used. Both gravity dam tanks and lakes must have very large capacities. In comparison, aquifer storage would probably be sized between 75 and 2,000 homes.

\subsubsection{Capital Cost}

The capital costs are high at the low end of the capacity range and lower at the high end. Capital costs can vary substantially and probably extend beyond the ranges shown in Figure 22. These capital costs are for the storage components alone and do not include source, use, and thermal transport system expenses. Ice, existing cavern, and lake categories have the potential for being lowest in cost. Lakes and existing caverns require very large capacities, however. Moderate costs can be expected for ponds, constructed caverns, gravity dam tanks, rock boreholes and earth storage. Conventional tanks are the most costiy. Aquifer storage capital costs, by comparison, would range from $\$ 20$ to $\$ 200 / 10^{6}$ Btu and would generally be lower than nonaquifer costs.

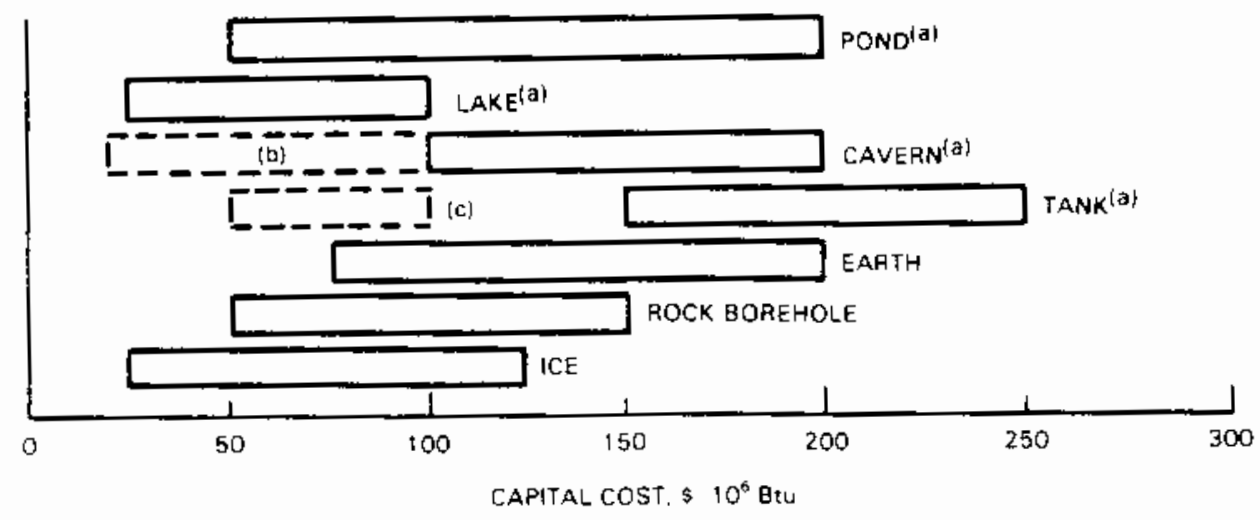

(a) CAN EXCEED ONE INVENTORY PER YEAR (b) NATURAL CAVEFN OR ABANDONED MINE (c) WITM GRAVITY OAM TANK

FIGURE 22. Approximate Capital Cost (Single Inventory Turnover) 
The capital costs shown in Figure 22 are based upon a single annual thermal inventory turnover. The uppermost four concepts shown in Figure 22 have the capability of multiple inventory turnovers per year. Multiple inventory reduces turnover storage cost. For example, for a common design and site, the pond cost range could be reduced to $\$ 25$ to $\$ 100$ per million Btu if two turnovers of inventory occur in a year. For five turnovers the cost range would be $\$ 10$ to $\$ 40$.

Figure 23 indicates how thermal energy operating costs can vary as functions of water storage capital cost ( $\$ 50$ to $\$ 400 / 10^{6}$ Btu capacity) and the annual storage inventory turnover rate (1 to 20 times/year). Annual levelized costs for operations, maintenance, and capital recovery were assumed to be about one-third the capital cost of a storage system. The cost of fuel 011 heat at $65 \%$ boiler efficiency was used as a line of reference.

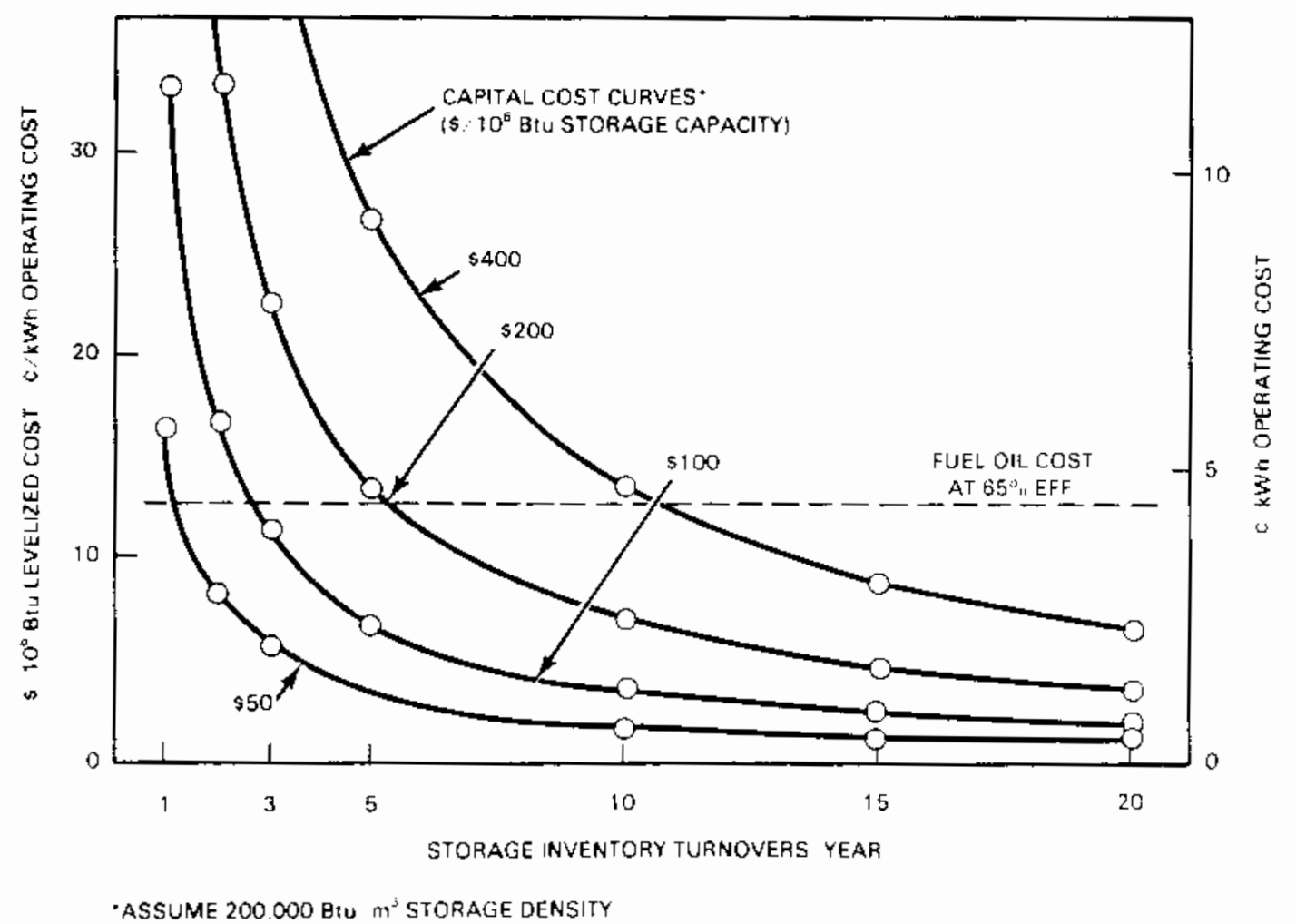

FIGURE 23. Approximate Costs Versus Inventory Turnover (Storage Only) 
Figure 23 also shows how increased storage costs can be justified by more frequent inventory turnovers. A $\$ 50 / 10^{6}$ Btu capita] cost system is needed to be competitive at one turnover, but at least 10 turnovers are needed at $\$ 400 / 10^{6}$ Btu.

Concepts such as tank, cavern, pand, and lake storage have the capability of multiple inventory turnovers because they can be efficiently charged and discharged within a short time. Therefore, even the most expensive tank storage can have STES applications.

\subsubsection{Thermal Effectiveness}

Table 5 indicates that the heat recovery potential for all concepts is good. When supplementary heat pumps are used, the recovery potential is further enhanced. Tanks are excellent because control of the thermocline, the gradual interface between waters of different temperatures, is easy to maintain. Ice storage is excellent because the heat of fusion assures a constant withdrawal temperature during cooling. Earth and rock boreholes are likely to require temperature boosting by heat pumps or fossil fuel burning to be feasible.

TABLE 5. Heat Recovery Potential (a) and Quality

$\begin{array}{ll}\frac{\text { Concept }}{\text { Pond }} & \frac{1 \text { Rating }}{\text { Lood }} \\ \text { Lake } & \text { Good } \\ \text { Tankern } & \text { Fair to Good (b) } \\ \text { Earth } & \text { Excellent } \\ \text { Rock boreho?e } & \text { Fair to Poor } \\ \text { Ice } & \text { Fair to Poor }\end{array}$

\footnotetext{
(a) $>80 \%$ potential for all concepts

(b) with insulation
} 


\subsubsection{Advantages and Disadvantages}

Advantages and disadvantages of nonaquifer systems are shown in Table 6. Pond technology is well advanced, but not with temperatures above $65^{\circ} \mathrm{C}$. Lake stores can be made very large and have the potential of being low in cost because modular construction can be performed quickly. Cavern construction usually leaves the surface area free for other uses.

TABLE 6. Nonaquifer STES Concept Main Advantages and Disadvantages

\begin{tabular}{|c|c|c|}
\hline Concept & Advantages & Disadvantages \\
\hline Pond & Technology good, many sites & Pond dam safety \\
\hline Lake & $\begin{array}{l}\text { Large size, low cost } \\
\text { potential }\end{array}$ & $\begin{array}{l}\text { Undeveloped, environmental and } \\
\text { regulatory hurdles, } \\
\text { alternative uses }\end{array}$ \\
\hline Cavern & Underground storage & $\begin{array}{l}\text { Some uninsulated caverns } \\
\text { require heat booster, high } \\
\text { excavation costs for new } \\
\text { construction }\end{array}$ \\
\hline Tank & $\begin{array}{l}\text { Technology excellent, good } \\
\text { site availability, thermaliy } \\
\text { effective, flexibility, } \\
\text { low cost }\end{array}$ & Higher cost \\
\hline Earth & $\begin{array}{l}\text { Site availability, potential } \\
\text { small capacity usage }\end{array}$ & $\begin{array}{l}\text { Site variations, low } \\
\text { temperature discharge heat }\end{array}$ \\
\hline $\begin{array}{l}\text { Rock } \\
\text { borehole }\end{array}$ & Low cost potential & $\begin{array}{l}\text { Variation and } 1 \text { imited sites, } \\
\text { low temperature discharge heat }\end{array}$ \\
\hline Ice & $\begin{array}{l}\text { Low cost, small capacity } \\
\text { usage, good technology, good } \\
\text { thermal effectiveness, } \\
\text { compact storage }\end{array}$ & $\begin{array}{l}\text { Site limitations for naturally } \\
\text { generated ice }\end{array}$ \\
\hline
\end{tabular}

Tank technology is the most advanced. Almost all sites can be used for tanks. High storage temperatures are no problem, and excellent recoveries are obtainable with adequate insulation. Multiple tanks can be used to improve efficiencies, and barriers can be installed to provide 
operating flexibility. Tanks provide a high degree of reliability and reduce the need for site characterization and environmental assessment.

Earth storage can be used at a large number of sites. It has the potential of being used for small size systems, such as individual homes or farms, if site characteristics are right and if it is used in conjunction with heat pumps. Rock boreholes (based upon Swedish studies) have very low cost because of utilizing in situ rock storage and insulation.

Ice storage also has low cost and can be used for systems down to single home size. Technology for ice production is established and should be adaptable to STES systems. Ice has good thermal effectiveness, and, as indicated earlier, its high heat of fusion allows for a dense thermal storage and cooling supply at a steady $0^{\circ} \mathrm{C}\left(32^{\circ} \mathrm{F}\right)$ temperature.

One disadvantage of cut-and-fill ponds is the hazard of flooding. Surprisingly, lake storage is not a well developed concept. Perhaps this slow development is caused by the large capacities ( $>2000$ homes) required to provide favorable economics. Also, environmental and regulatory obstacles will have to be overcome. Natural lakes may have competing uses, such as water supply, fishing, recreation, and shipping, that reduce the sites available for energy storage.

Natural caverns may require booster heat because of heat loss through the rock walls. Excavated caverns are much more costly than existing caverns. Tankage costs are relatively high; tanks will usually require more than one annual inventory turnover to be competitive.

The economics of storage of materials, such as sand, clay, and gravel, can vary substantially. Earth storage concepts that require substantial excavation will be costly. Earth material with either low specific heat or high thermal conductivity will likely require heat pumps or booster heat (or chill) to be usable. Rock borehole storage must cope with site variations. As with earth storage, the heat will be discharged at temperatures significantly less than charging temperatures. Ice storage is limited to sites where climatic conditions permit economic freezing. 
The effective capacities of TES systems can be nearly doubled by the use of heat pumps. Heat pumps also withdraw heat from the earth source. Conversely, heat pumps can reject heat to either earth or atmosphere. Heat pumps can enhance the flexibility of STES systems by permitting intermittent boosting of heat flow.

\subsection{CONCLUSIONS}

It is apparent that additional research and demonstration is needed for all of the nonaquifer STES concepts. Tank storage requires the least amount of research and lake storage the most. Development of lining and insulation systems are requirements common to all concepts. It appears that coupling of solar energy with small to intermediate STES has good potential. On the large scale, use of waste heat from power and industrial plants has tremendous potential.

Economics favor ice storage for small to large capacities, existing caverns for intermediate to large capacities, and lake storage for large capacities. All of the concepts are capital-intensive; therefore, future implementation depends upon electricity and fuel costs escalating more rapidly than general inflation and/or the establishment of a national policy to conserve energy resources.

Thermal recoveries can be good except that earth and rock borehole concepts will achieve satisfactory thermal recovery only. All concepts except ice use sensible heat, are therefore subject to declining temperatures, and may require heat pump or booster heat (or chill) to maintain efficient operation.

The best site availability occurs for tank, earth, and pond stores. Usually at least a 50-home capacity is needed to make a store cost- and thermal-effective. A 1- to 50-home capacity may be possible for ice storage. It may also be possible for less than 50 homes to use tank and storage where multiple annual inventory turnovers are possible because of the use of solar or steady waste heat sources and perhaps when used with heat pumps. Earth storage may be used for one or more homes when it is combined with heat pumps. 
The number of annual thermal inventory turnovers is an important factor when considering economic justification for a storage system. Use of heat pumps can also enhance the economics through increased capacity, improved coefficient of performance, and flexibility in operations.

No single concept is best for all sites. All concepts, except tanks, are very site-specific. They are also capital-intensive and must be designed to take advantage of site characteristics and the local thermal source and use requirements.

Currently, the most attractive areas for performing research appear to be in the least costly methods. The less economic concepts will recejve increasing attention when power and fuel costs increase more rapidly than general inflation and when pressures for energy resource conservation increase. 


\subsection{FOREIGN STUDIES IN SEASONAL THERMAL ENERGY STORAGE}

Brief reports of progress in STES in Sweden, Germany, China, The Netherlands, Canada, Denmark, Switzerland, and France are presented. The results reported below were drawn from the sources indicated and were neither modified nor reinterpreted.

\subsection{SWEDEN}

The most extensive research and development efforts in seasona 3 thermal energy storage are taking place in Sweden (Svedinger 1981). Various types of energy storage and heat source are of major interest in the Swedish national program for energy conservation. The Swedish Council for Building Research initiated about 150 projects before 1980 involving heat storage in soil, rock, and water. Technical and economic feasibility of underground thermal energy storage is being studied for space heating.

Current Swedish research is underway in two major categories:

- techniques for extracting terrestrial heat (geothermal energy) by heat pump from subsoil, groundwater, lake and seawater, and solid rock

- techniques for storing heat within a discrete subsurface volume and using solar energy, waste hot water, or other sources. Heat is stored in water-filled pits or caves, aquifers, solid rock, clay, or peat. Storage is directly connected to the distribution system or connected through a heat pump for storage temperatures below $100^{\circ} \mathrm{C}$.

Three favored heat storage technologies are the water-filled insulated steel tank, the water-filled rock cavern, and the multiple well system in solid rock (Lindbo and Bruce 1981). Cost comparisons show that the multiple well system is least expensive in the range from 3 to $20 \mathrm{GW}$. Above $5 \mathrm{GW}$ the rock cavern holds the intermediate position. However, the multiple well system has less energy efficiency than the steel tank and thus requires use of more solar collectors. 
The multiple well heat storage system was described in more detait by Andersson and Eriksson (1981). The wells are parallel and positioned in a square array. The heat storage capacity of granite and gneiss is about $0.6 \mathrm{kWh} / \mathrm{m}^{3}-{ }^{\circ} \mathrm{C}$, about half that of water. Hence, a multiple well heat storage system must have a volume twice that of a water storage cavern. The working fluid can be circulated through the wells in an open or closed circuit. In the closed circuit, the fluid is circulated through $\mathrm{U}$-shaped tubes inserted into the wells. Groundwater transfers the heat to and from the tube and rock. In the open circuit, the fluid is conducted through the tube to the bottom of the well where it is released in direct contact with the rock. To limit heat and water loss and geochemical reactions, the host rock should be relatively impervious and unreactive. A thermal recovery efficiency of $90 \%$ was predicted, the forecast of Lindbo and Bruce (1981) notwithstanding. Results were not available at this writing.

Hultmark (1981) reported results from the first year of operation of Sunclay Project, seasonal storage of solar energy within $80,000 \mathrm{~m}^{3}$ of clay. A calcium chloride aqueous solution heated to 15 to $30^{\circ} \mathrm{C}$ transfers energy through vertical $U$-shaped plastic pipes inserted to a depth of $35 \mathrm{~m}$. Heat pumps driven by diesel engines take energy directly from the solar collectors or from the heat store and add waste heat from cooling water and exhaust gases. The system reduces oil consumption for heating by two thirds. The pay-off period is about 8 years.

"Sunstore" is a conventional solar heating concept in which thermal storage is achieved by passing heated water through vertical concentric "return" tubes 2 to $4 \mathrm{~m}$ apart and penetrating rock or clay to a depth of 30 to $100 \mathrm{~m}$ (Plate1] 1981). Very low costs per cubic meter of storage were experienced, even when the temperature range was oniy $10^{\circ} \mathrm{C}$. Solar energy is collected by unglazed roof or facade materials, which operate satisfactorily at low temperature. A small demonstration plant, funded by the Swedish Council for Building Research and the National Swedish Board for Technical Development, was built for a one-family house in Sigtuna, using 10 cubic meters of rock below the house as the heat store. 
A test plant for storage of heated water in an unlined $15,000 \mathrm{~m}^{3}$ cavern at Avesta was described by Martna (1981). The fuels are refuse and peat. The heating plant coolant circuit and thermal reservoir are connected by heat exchanger to protect the boiler from mineral deposits. The demonstration was designed to measure heat losses, cavern stability, thermal layering of the water, changes in water chemistry, and influences on the environment.

The block-filled rock cavern and pond are realistic alternatives for STES applications (Lindblom et a1. 1981). Unmucked blasted rock inside the storage volume stabilizes the rock walls, whereby very large and high storage rooms can be created. This is an effective and inexpensive excavation technique known from large-scale mining operations underground. Because of the large compact volumes, the thermal losses from contained water to surrounding rock will be quite low. The pond may be economical for a market of several thousand dwellings, whereas the larger cavern is better suited for cities. The theory of thermal dispersion in rock-fills was experimentally verified.

\subsection{FEDERAL REPUBLIC OF GERMANY}

Large-scale thermal storage systems are being developed in Germany to use waste heat from power plants and low temperature solar heat. Storage reservoirs include insulated artifical lakes and artifica? aquifers (Friedrich and Lottner 1981). Current German efforts in STES R\&D also encompass thermochemical storage.

\subsubsection{Artificial Storage Lake}

Early work in Germany was concentrated on the development of a heat-insulated, leakproof, artificial storage lake. It was assumed that this concept could be realized simply, without technical difficulties, and inexpensively. Today advanced concepts require that water be stored at temperatures up to $100^{\circ} \mathrm{C}$. Several conditions are required for large district-heating networks:

- Only capacities of $10^{5}$ to $10^{6} \mathrm{~m}^{3}$ can be considered. The large volumes reduce thermal losses and construction costs. Cylindrical 
steel tanks cannot meet the volume requirement because they are limited to a maximum size of $10^{5} \mathrm{~m}^{3}$.

- The seasonal thermal storage reservoir must be well insulated and leakproof so that oxygen-free water can be stored at about $100^{\circ} \mathrm{C}$. High temperatures increase the thermal capacity. Water can be fed directly into district heating networks, eliminating expensive heat exchangers.

- In the reservoir itself it must be possible to maintain stratification of cold and hot water (so that a second reservoir is unnecessary).

- It must be possible to build the reservoir so inexpensively that storage over the whole year is economically feasible. For today's energy prices, this requires that the specific building costs of about 30 to $50 \mathrm{DM} / \mathrm{m}^{3}$ should not be exceeded. This condition cannot be met by cylindrical steel tanks because their construction costs are substantially higher.

Mixing during the charging-discharging process is limited to the area of entry and has no effect on the function of large water storages, if the quantity of mass flow is kept within defined limits. For longterm storage this mixing is of minor importance compared with heat conduction and convection processes. Apart from the area at the rim of the side walls, there is a stable horizontai temperature distribution over the whole volume. Convective flows lead to additional exergetic losses. Simple models allow the temperature distribution and losses to be calculated fairly accurately.

Inlet-outlet devices must be fixed at the water surface and on the bottom of the reservoir. Water must be fed in as horizontally as possible so dual slits in the pipes or plate-shaped distributors are used.

The artificial storage concept can be realized only with considerable technical effort and risk. Aithough it was first planned to build the storage lake by "heaping up dams" and using simple plastic 
sheeting as insulation, for safety reasons more effort had to be given to material choices for wall construction and sealing.

Particular technical problems affect the storage of hot water above $70^{\circ} \mathrm{C}$. Unfortunately no special plastic sealing and insulation materials have been developed for this application satisfying all requirements of temperature, pressure, and resistance to water vapor diffusion.

Only expensive and easily broken foam glass (which must be protected from possible hydrolysis) can be considered for wall construction. In the storage project in Mannheim, two alternative possibilities for sealing were investigated: plastic sheeting and special asphalt concrete. However, neither material assured adequate resistance to creep and water vapor diffusion. Bentonite layered with concrete and foam glass showed an apparently acceptable diffusion rate at $95^{\circ} \mathrm{C}$.

Construction of walls from several layers could be simplified if a suitable, inexpensive plastic material were available that satisfied the simultaneous requirements of pressure, temperature, low vapor-diffusion rate and had good insulating properties.

A new storage concept being tested embodies segmented steel in the shape of a flat shell. Stores could be built in any dimensions required (height: $10-15 \mathrm{~m}$ ). By curving the side walls, it should be possible to obtain a constant tensile stress so that only a small thickness of steel (6 to $10 \mathrm{~mm}$ ) would be required. The thermal insulation would be protected from pressure and dampness by the steel sheet, so that a less costly standard material could be used, and lower construction costs could be obtained.

\subsubsection{Artificial Aquifer Storage}

In the artificial aquifer storage concept the volume is separated from geologic surroundings by vertical side walls of bentonite and the inner soil is replaced by a gravel bed. The water iniet and outlet at the top surface and on the floor are connected by a piping system. The bentonite walls have a very low water permeability and prevent hot 
storage water from mixing with groundwater in the surroundings. Use of gravel and crushed stone in the store raises permeability so that a high rate of water removal is possible and lower pressure losses occur. With this method of construction the storage volume is rendered finite and can be used particularly in short term operation; therefore, in comparison with natural aquifer reservoirs, higher construction costs can be tolerated.

The concept of artificial aquifer storage is similar to that of the insulated artificial lake. In both cases horizontal thernal stratification occurs, and energy is charged and discharged with water. However, the specific energy density of the artificial aquifer storage is about 40\% lower than in lake storage. A further disadvantage is that water

from the aquifer store may be corrosive and therefore the heat cannot be fed directly into the district heating network but only through an expensive heat exchanger. On the other hand, the building construction, particularly the covering, is simpler, and the storage surface can be used for other purposes more easily.

\subsubsection{Thermochemical Storage}

Apart from natural aquifer storage, long-term storage of sensible heat can be realized only with a relatively great technical effort (regarding heat insulation and building construction) and only in large-scale thermal storage systems. Therefore, its use requires district heating networks and a high density of heating demand. The installation of such systems for decentralized heat supply in sparsely populated areas is not practicable.

On the other hand, thermochemical storage of low-temperature heat offers several advantages:

- expensive heat insulation is not required

- the storable energy density is considerably higher by a factor of 10 than in the case of water stores

- the storage is also suitabie for decentralized heat supply. 
For several years various thermochemical reactions have been investigated in Germany for the long-term storage of low-temperature heat (waste heat from power stations, solar energy from flat-plate collectors). In particular, the absorption of water vapor in molecular sieves (zeolites) and silica gel with air as the carrier medium was studied. Although these materials have lower specific energy densities than aqueous sulfuric acid, storing large amounts is not dangerous. In one year a well-insulated house reqires about 20 to 40 metric tons (MT) of zeolite material for heating and hot water.

A small pilot storage plant has been built at the University of Munich. Measurements under real operating conditions are being carried out to optimize the system (dimensioning, individual process steps) to provide basic data for the design and construction of larger plants. However, a series of fundamental problems (e.g., how to reduce the required auxitiary energy and how best to dry the zeolite) has made an intensive investigation necessary.

Currently, thermochemical long-term thermal storage is also confronted with difficult problems regarding economy and energy pay-back time. The current price of pelletized zeolite (DM 6 per $\mathrm{kg}$ ) is still far too high; the energy pay-back time for zeolite is rated at $g$ years. These two figures could be considerably reduced in the future.

\subsection{PEOPLES REPUBLIC OF CHINA}

In the late 1950s, widespread industrial use of groundwater in Shanghai caused 1 and subsidence and a large drop in the water table (Yan 1981). Several factories experimented with reinjection of cold water from air conditioning systems to replenish groundwater. Over the next few years these efforts were generally successful in raising water table levels and increasing the outputs from production wells. In addition, reinjection and well construction methods were continually improved through experiments with different techniques, volumes, and injection periods. 
During spring and summer of 1965, the Shanghai Cotton Mill Factory initiated a large-scale artificial recharge experiment with four different water sources: deep well water, industrial waste water, filtered industrial waste water, and tap water (Allen 1979). Researchers also experimented with continuous versus intermittent withdrawal and with different reinjection/shut-in cycles. Temperature changes and water quality were monitored both before and after injection. These experiments indicated that there was little regional water flow in the aquifer and that only small changes occurred in the temperature of water stored. These results justified later projects involving winter injection of cold water for summer use and summer injection of hot water for winter use (Yan 1981).

Also in 1965, the Shanghai Water Company conducted extensive experiments on various reinjection methods with three specially designed reinjection wells $95 \mathrm{~m}$ deep to study changes in groundwater level, water quality and temperature. Their experiments yielded relatively complete quantitative records that confirmed the effectiveness of using gravity recharge and underground production methods to raise groundwater leve1s. Injection methods are classified by the words "vacuum", "gravity", and "pumped." Vacuum injection is described as "used for aquifers with rather low static water levels $(10 \mathrm{~m}$ below the surface) which form the vacuum and good permeability" (Yan 1981).

Based on the results of these large-scale experiments and their own studies, the City of Shanghai Hydrogeological Group concluded that reinjection was able to effectively control subsidence and groundwater levels and that it was possible to store cold water in winter for summer use in air conditioning. These conclusions led to a city-wide reinjection program in which 70 factories used 134 deep wells for simultaneous recharge. As a result, the water level increased by more than $10 \mathrm{~m}$.

Groundwater produced during summer had a very low temperature and thus became a new source of chilled water for industrial use. At the conclusion of summer reinjection pumping the land level had increased 
$6 \mathrm{~cm}$. This was the first time in several decades of continuous subsidence that any surface uplift had been observed.

The efficiency of cold water STES has been examined within gravel aquifers beneath river terraces near the cities of Xian and Nanchang. Three operating conditions were beneficial: 1) prevention of nearby water extraction (from wells), 2) injection of cold water into the funnel region of a descending water table, and 3) recovery of water from "valleys" in the aquifer floor formation (Yan 1981).

Three types of permeability degradation were recognized: physical clogging by sand, colloidal substances or entrained air; chemical clogging by corrosion, oxidation or calcium carbonate deposition; and biochemical development of $\mathrm{Fe}(\mathrm{OH})_{3}$ from iron bacteria. Reverse pumping, backwashing, and hydrochloric acid treatment have been used to alleviate clogging (Yan 1981).

The program in the Peoples Republic of China has expanded in recent years; several hundred wells are now in use. Production and injection methods are said to have been greatly improved, and the program now includes summer injection of hot water for use in winter. Because of the success at Shanghai, several industrial cities and large villages have adopted similar reinjection and thermal energy storage programs.

\subsection{THE NETHERLANDS}

In one project, 100 solar houses with seasonal heat storage in ground soil will be built in Groningen. This research project is the national test case for the Netherlands in the International Energy Agency task "Central Solar Heating Plants with Seasonal Storage" (Wijsman 1981).

A conventional solar heating system for a house consists of a collector array mounted on the south-facing roof and a short-term (ST) heat storage reservoir. This solar heating system delivers part of the heat demands for space heating and domestic hot water. The ST-heat storage reservoir stores the surplus of heat collected on a clear day for use on a cloudy day. An important increase of the solar 
contribution can be expected by extending the system to seasonat or long-term (LT) heat storage. The collected surplus of solar heat in summer is stored for consumption in winter.

Large water reservoirs can be used for seasonal heat storage, but are expensive. A less costly solution uses the upper layer of the soil as the storage medium. The validity of this concept was proven by the Delft Soil Mechanics Laboratory in cooperation with Philips Energy Systems, Eindhoven, and the Institute of Applied Physics TNO-TH, Delft. The seasonal heat storage reservoir in the soil is nothing more than a layer of soil (up to a depth of approximately $20 \mathrm{~m}$ ) with a heat exchanger. The reservoir is not bounded by walls. It is furnished with a foam insulation layer only at the top; at the sides, the soil itseif acts as insulation. The heat exchanger, in which the heat exchange between the transfer and storage media takes place, consists of vertical tubes.

Because of heat transfer by conduction, the seasonal heat storage reservoir loses heat to the surrounding soil. To perform satisfactorily, the reservoir must be large. Therefore, a group of solar houses connected to a central storage reservoir is essential for seasonal heat storage. Additional heat losses can occur by convection of the groundwater in porous soil. In some cases vertical barriers are necessary to limit heat loss.

To predict the solar contribution from seasonal heat storage in the soil, a computer simulation model for a group of solar houses connected to a central heat storage reservoir in the soil was developed. Hourly weather data were input. The model of the seasonal heat storage reservoir was based on heat transfer in the soil by conduction onty. The computer simulation model determined the total solar contribution for several system configurations, and obtained a good approximation of the various heat fluxes in the total system.

From a parameter sensitivity study, it appeared that the collector type and the heat losses in the piping network are important items. A low-temperature heating system in the houses is desirabie. Because of 
the 1 imited roof area for terraced houses, the number of solar collectors that can be mounted onto the roof is limited to 25 to $30 \mathrm{~m}^{2}$; to get near to $100 \%$ solar contribution, the heat demand of the houses must therefore be low (less than $6 \mathrm{kw}$ at design conditions).

\subsection{CANADA}

An overview of Canadian aquifer thermal energy storage field trials was presented by Morofsky (1983).

Canadian seasonal energy storage activity began in the 1970s in latent energy storage of winter ambient temperatures as ice and tank storage of solar heated water. The tank storage work was stimulated by proposed solar designs providing a large proportion of building space heating needs. Analytical numerical models of sensible heat storage as well as simplified design methods based on them were developed at the University of Toronto (University of Toronto 1980, 1982). A single family residence and a thirty-unit apartment building were constructed with solar energy seasonally stored in tanks. Long term latent energy storage for summer building cooling was initiated by Public Works Canada (PWC). The first field experiment was conducted in 1979, and recent field trials were performed under contract to $P W C$ and perfected an automated ice formation and energy extraction method (Morofsky, 1982a). A full-scale application is planned for the 1983-84 winter. The overall potential of applying natural cooling techniques in Canada has been assessed. Latent energy storage in the form of ice and cold water storage in aquifers was judged to be competitive with conventional cooling practices in a range of applications. Typical groundwater temperatures in Canada are within several degrees Ceisius of those required by building cooling systems. Direct cooling at the natural temperature is most economical and is widely practiced in winnipeg, Manitoba. 8ecause the water is not reinjected, well interference has resulted, and a gradual warming of the aquifer has been noted.

A study of the technical and economic feasibility of aquifer based cooling (Energy, Mines and Resources 1979) indicated that it might be 
cost competitive on new buildings, although certain technical assumptions required confirmation in the field. The Atmospheric Environment Service (AES) building in Downsview, Ontario, was chosen as a site because ot its large size (30,000 square metres), extensive land area available for field work, and the high probability of finding a suitable aquifer. The AES buitding and land are owned by PWC. Extensive field work was undertaken during 1981-82 including pumping tests, water quality analyses, geotechnical assessment, heated water injection, and surveying. Evaluation of the data, including modeling alternative well configurations, has led to a final design of a three doublet well configuration (Public Works Canada 1981, 1982a). A seasonal energy storage field trial facility will be associated with the Scarborough Town Centre Government of Canada Building scheduled for occupancy in 1985 (Morofsky 1982b). A confined, artesian aquifer will be able to store winter chill, reject heat from the chillers, or excess solar energy. The aquifer may also serve as a constant-temperature heat sink for the heat pumps if stored energy has been exhausted. Construction at the Scarborough site began early in 1983, while funding for the AES demonstration is presently being sought.

\subsection{OENMARK}

Warm-water storage in a near-surface aquifer is being demonstated in Denmark (01sen and Reffstrup 1983).

A site for a possible location of the demonstration storage plant was selected at Horsholm. This area was chosen because of the probability of acceptable geological conditions, combined with the existence of an incinerator plant with an associated district heating network.

During the subsequent geological investigations, which included drilling of test wells and pump tests, it appeared that a confined aquifer with a thickness of about $15 \mathrm{~m}$ existed, with a depth to the top of the aquifer of about $10 \mathrm{~m}$. The aquifer material is sand with a porosity of about $30 \%$ and a permeability of about 10 Darcies. There is 
a potential gradient across the aquifer of about $3 \%$, resulting in a small regional flow of groundwater. The water has a relatively high calcium hardness (Hagelskjaer et al. 1983).

The store is connected to an incinerator plant with its associated district heating network. Because the plant is not able to store a large amount of combustible refuse, the incineration rate is kept constant through the year. Moreover, the incinerators are not sized to meet the peaks of the heat demand, so the plant has to supplement its output with heat from oil-fired boilers during the winter. During a period in the summer, there is a surplus production of heat. During weekends, when no refuse is burned, the demand is also covered by oil-produced heat. The outlet temperature of the system is $105^{\circ} \mathrm{C}$, and the return temperature is $63^{\circ} \mathrm{C}$.

A central well is surrounded by four peripheral wells situated on a circle with a diameter of $80 \mathrm{~m}$. The wells are connected to a heat exchanger station located in the machinery house, which also contains such additional mechanical equipment as booster pumps and a water treatment plant. Instrumentation wells are drilled into the storage aquifer for temperature measurements. Two relief wells stop groundwater flow through the storage reservoir (Hagelskjaer et al. 1983).

The volume of the storage reservoir is about $75,000 \mathrm{~m}^{3}$. With a scheduled storage temperature of $100^{\circ} \mathrm{C}$ and return temperature from the district heating system of 65 to $70^{\circ} \mathrm{C}$, the amount of stored energy is about 6 TJ (about 1500 Gcal or $1740 \mathrm{MWh}$ ).

The central 14-in. well is equipped with a 10-in. screen. The well is screened over the entire aquifer height, except for a length of $1 \mathrm{~m}$ that divides the screen into two parts. Between these two parts, a hydraulically controlled valve is inserted, which makes it possible to close off the lower part of the screen.

The 10-in. peripheral wells are equipped with 6-in. screens, which are placed in the lower third of the aquifer height. 
The well screens are made from acid-proof stainless steel, which makes it possible to dissolve any depositions in the wells by chemical treatment. The perforation around the well casings of the upper layer of clay is sealed with a water-resistant cement.

The pump wells are equipped with variable-flow borehole pumps, dimensioned for a total flow through the system of $80 \mathrm{~m}^{3} / \mathrm{h}$.

Because a temperature difference of only $3^{\circ} \mathrm{C}$ is expected between the outlet and return temperatures of the district heating system, plate heat exchangers are used.

To prevent precipitation of calcium carbonate, a small amount of hydrocloric acid is added to the groundwater before heating. The carbon dioxide produced is removed in a degasser. This method also prevents gas formation during heating. The amount of hydrocloric acid added wilt result in only a small increase in the natural concentration of cloride jons in the aquifer.

After the heat exchangers, the groundwater passes a cyclone filter, which removes particulates before the water is reinjected and prevents clogging of the wells.

Since the completion of the plant was delayed, the initial heat injection experiment did not take place until the end of the summer season when only a limited time was left for storage of waste heat. Therefore, the initial experiment was kept to a smail scale.

The injection conditions were:

- injection temperature (average) I bar above the hydrostatic pressure

- injection flow 20 to $30 \mathrm{~m}^{3} / \mathrm{h}$

- total injected heat energy $235 \mathrm{GJ}$ (56 Gcal or $65 \mathrm{kWh}$ )

- accumulated injection time 150 hours (distributed over 12 days)

Because permeability is highest in the lower part of the aquifer, the valve in the central well was closed during injection to restrict the flow to this section. 
When injection was complete and a waiting period of three weeks had elapsed, discontinuous heat withdrawal was started. In the beginning of this phase, the recovery temperature was $34^{\circ} \mathrm{C}$, which is $2^{\circ} \mathrm{C}$ below the injection temperature.

The withdrawal was stopped when the reservoir temperatures in the observation well had decreased to approximately the original vaiues. The final withdrawal temperature was $17^{\circ} \mathrm{C}$, and the total recovered heat energy was about $55 \%$ of the injected energy.

The results of the mathematical simulations and the practical experiments give a favorable evaluation of the storage concept.

In addition to the Hørsholm facility operation, the project calls for selection of possible sites for locating second-generation storage facilities. To date, three areas with suitable geology and local heat supply planning have been selected.

The potentials for aquifer thermal stores in Denmark are good if a reasonably high recovery factor can be demonstrated. A demand for the storage of heat exists in connection with industries with a waste production of heat, district heating plants, incineration plants, and cogeneration plants. Furthermore, a suitable geology is available in most areas of the country.

\subsection{SWITZERLAND}

A large-scale underground heat storage plant, called project SPEOS, was designed to explore a novel water circulation approach (Saugy et al. 1983). The project concerns warm-water storage in a saturated porous medium during the summer months of low energy demand. The system is based on the vertical water movement induced by two leveis of horizontal radial drains drilled from a vertical central well.

Warm water $\left(70^{\circ} \mathrm{C}\right)$ is injected into the aquifer through the upper radiant drains ( $25 \mathrm{~m}$ long, $7 \mathrm{~m}$ below soil surface). It is extracted simultaneously from lower radiant drains $(25 \mathrm{~m}$ long, $24 \mathrm{~m}$ below surface). During the production period, the process is inverted and 
warm water is extracted from the upper drains. The vertical component of flow is needed to reduce the effect of natural convection within the aquifer. The injection power is $500 \mathrm{~kW}$, and expected efficiency is $35 \%$ for the first yearly cycle and $45 \%$ for the following cycles. It is planned to integrate the storage plant in an energy network. Energy would be supplied by waste heat and solar collectors. The heat produced during the winter would either meet the demand of a nearby gymnastics hall, or be injected into a school space heating system.

The first cycles of the pilot plant led to the following conclusions :

- The behavior of the aquifer matches predictions of preliminary simulations.

- The main well, horizontal drains, and installation were realized successfully and within the given time frame.

- Operating a low-temperature heater with variable flow will require further technical advances in the field of heating installations.

- The first injection phase was achieved successfully without clogged drains and with limited difficulties related to equipment management.

- Present results conform to the predictions and confirm the interest of SPEOS for seasonai heat storage at medium temperatures.

\subsection{FRANCE}

An overview of French activity in the field of aquifer heat storage is summarized (Iris and Marie 1983).

Research work in the field of aquifer thermal energy storage began in France in the middle of the 1970s, on both the experimental and theoretical planes.

Numerical models of simulation have been developed at the Bureau de Recherches Geologiques et Minieres and at the Ecole des Mines de Paris. 
Other theoretical works concerning the thermal behavior of the unsaturated zone overlying aquifers have been undertaken to study the mechanisms of heat losses through the soil surface and to evaluate the influence of a storage facility on soil mechanics.

Two major experiments have been conducted to compare the results of numerical simulations and field data. The "Bonnaud experiment" (Jura) was performed by the BRGM and Ecole des Mines de Paris from 1975 to 1977. The "Campuget experiment" in the south of France was performed by the Ecole des Mines in 1977 to 1979; in it, 20,000 $\mathrm{m}^{3}$ at $35^{\circ} \mathrm{C}$ have been injected in a phreatic unconfined aquifer at $15^{\circ} \mathrm{C}$ in summer and partially recovered the next winter.

The major result of these tests was the validation of the numerical models, the calculated results fitting well with the in situ measurements.

No major problems of clogging appeared during injection, but the water quality was found to be a major parameter in judging the feasibility of a storage plant. 



\subsection{ECONOMIC ASSESSMENT}

A major component of the U.S. DOE-funded Seasonal Thermal Energy Storage Program was economic assessment. This activity consisted of four subtasks: 1) development of a system for quantifying the economic parameters in aquifer storage configurations; 2) analys is of ATES for heated water; 3 ) analysis of ATES for chilled water; and 4) evaluation of alternative storage concepts for chilled water.

The first subtask culminated with development and documentation of the computer model AQUASTOR (Huber, Brown, and Reilly 1982). The model optimizes system design and calculates the life-cycle cost of district heating (cooling) with thermal energy supplied by an ATES system coupled to a seasonal energy source. The remaining three subtasks are described in detajl in the following subsections.

\subsection{AQUIFER STORAGE OF HEATED WATER}

The cost of energy supplied by an aquifer thermal energy storage (ATES) system, originally energized by the injection of purchased hot water, was investigated. Costs were estimated for point demand, residential development, and multidistrict city ATES systems with the computer model AQUASTOR. In this analysis, the cost effect of varying wide ranges of technical and economic parameters was examined (Reilly, Brown and Huber 1981a,b). Those parameters exhibiting a substantial influence on ATES costs were:

- purchased thermal energy cost

- capital cost

- source temperature

- system size

- transmission distance

- aquifer efficiency.

Purchased thermal energy cost is the major cost component of ATES delivered energy at purchase prices as low as $\$ 2 /$ MBtu. The purchase 
price of thermal energy is magnified by price escalation and by thermal losses to the surroundings.

Aquifer thermal energy storage systems for warm water are generally capital-intensive projects. Thus, the cost of financing is important in determining a system's cost-effectiveness. Municipalities obtain financing at substantially lower interest than is available from private entities because of the difference in tax status on bond interest. For this reason a municipality can consider a broader range of other system parameters as part of a potentially cost-effective ATES system.

The source temperature deliverable to an ATES system plays an important role in system economics. Higher storage temperatures are expected to yield poorer thermal efficiencies because of tilting of the themocline within the aquifer and conductive losses at the "bubble" interface. Despite the poorer thermal efficiency, a higher source temperature ultimately allows a higher deliverable temperature to the user with more usable energy per unit mass of water. This higher energy density allows lower system fluid flow and directly reduces the amount of piping, pumping, and well drilling required. of course, higher temperature sources will probably command a higher purchase price.

Significant economies of scale are available for ATES systems. In fact, fairly large systems are required to achieve cost-effectiveness. For point demand systems, costs are fairly constant for peak demands (at $25 \%$ load factor) 8 to $10 \mathrm{MW}$ and larger. Costs rise quickly for systems with peak demands less than 3 to $5 \mathrm{MW}$. Residential developments achieve the available economies of scale at larger system sizes because of the addition of extensive distribution piping networks.

Lengthy transmission distances can quickly result in prohibitive costs, especially for smaller (less than 5-MW) ATES systems. Extensive transmission systems can substantially increase system capital cost as well as increase the thermal loss to surroundings. Larger ATES systems are somewhat shielded from these cost effects by the large economies of scale available in piping systems (Reilly, Brown and Huber 1981a,b). 
Further study is required to accurately characterize the purchased energy cost for typical industrial and waste heat sources and to characterize ATES economic status for chill storage and continuous or nonseasonal sources.

The availability of a suitable aquifer is obviously of prime concern when considering an ATES installation. Potential site-specific availability of aquifers has not been addressed. This analysis assumed availability of a suitable aquifer and examined the cost effect of a range of possible thermal efficiencies. As expected, aquifer thermal efficiency is an important ATES cost parameter, especially with high purchased thermal energy costs.

Costs of ATES-delivered energy are compared in Figure 24 with those of hot water produced with more conventional fuel sources. Levelized costs for electrically heated water (at $5 \$ / \mathrm{kWh}$ and $7 \%$ annual escalation) and oil-heated water (at $\$ 1.00 / g a l l o n$ and $8 \%$ annual escalation) are compared with costs for an ATES point demand configuration [at $10 \mathrm{MW}$ and $163^{\circ} \mathrm{C}\left(325^{\circ} \mathrm{F}\right)$ source temperature $]$. Costs of ATES are shown as a function of purchased thermal energy. Figure 24 shows both the potentially low delivered energy costs available from an ATES system and its strong cost dependence on the cost of purchased thermal energy.

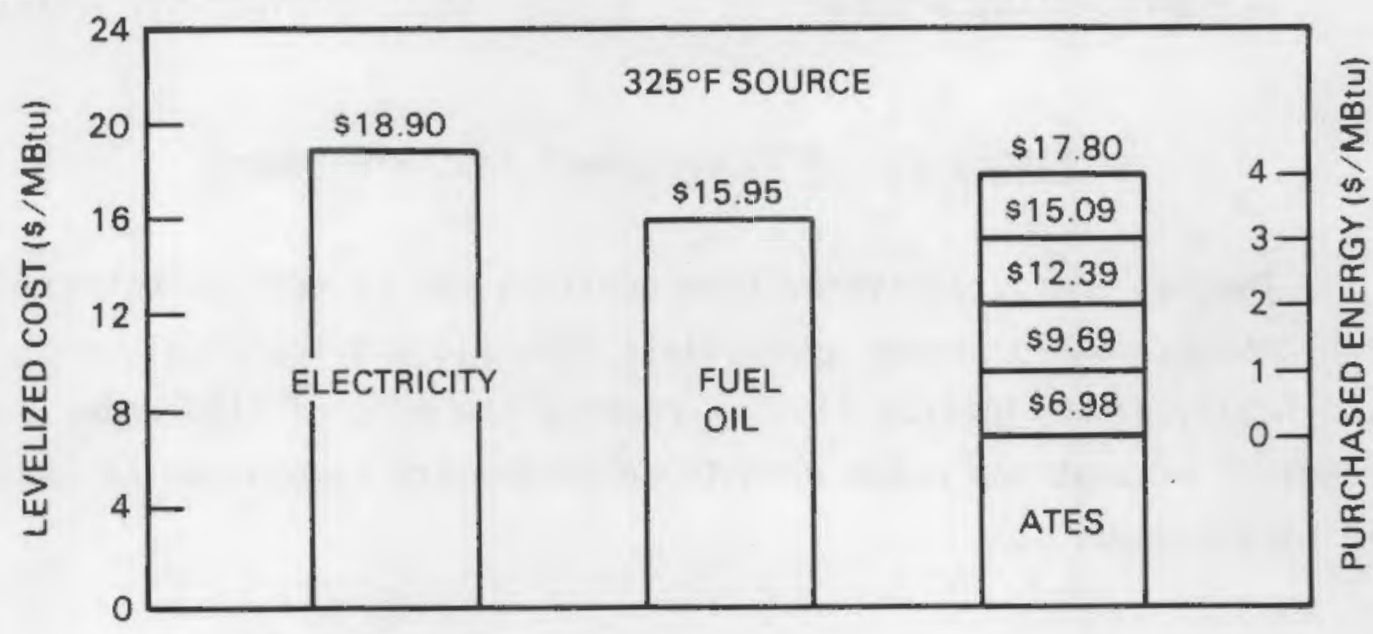

FIGURE 24. Cost of ATES Versus Conventional Technology 
Cost components are shown in Figure 25 for point demand and multidistrict city ATES systems. Capital and thermal energy costs dominate. Capital costs, as a percentage of total costs, increase for the multidistrict city from the addition of a large distribution system. The proportion of total cost attributable to thermal energy would change dramatically if the cost of purchased thermal energy were varied.

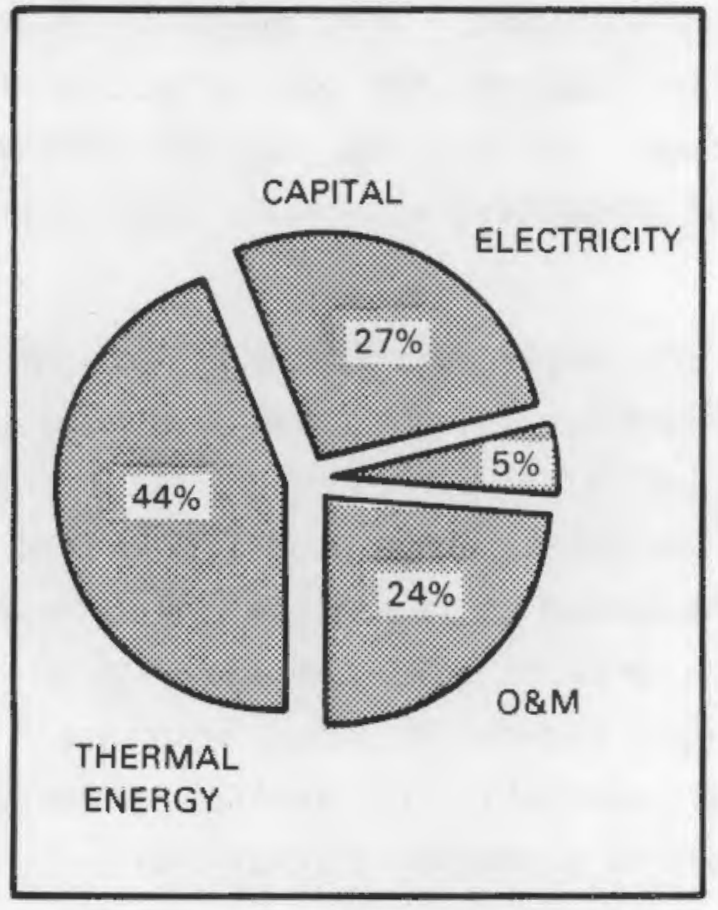

POINT DEMAND SYSTEM

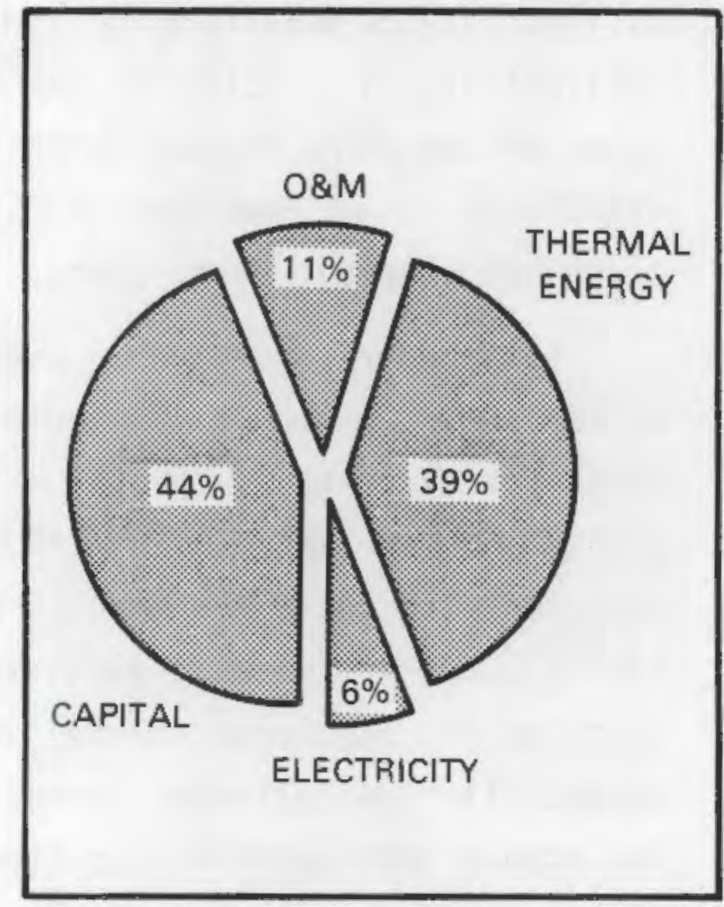

MULTI-DISTRICT CITY SYSTEM

\section{FIGURE 25. ATES Component Cost Breakdowns}

Thermal energy delivered from aquifers can be cost competitive with conventional energy under appropriate economic and technical conditions. The Reilly investigation (1981a) reports the cost of ATES under a wide range of assumptions based upon those parameters recognized as important to ATES economics. 


\subsection{AQUIFER STORAGE OF CHILLED WATER}

Two separate investigations sought to define the costs involved in supplying energy with an ATES system coupled with a chill source. The first (Brown 1983) employed the AQUASTOR code to estimate costs of a theoretical system. The second study (Kannberg et al. 1982) resulted in cost estimates for a specific ATES chill site, the Stony Brook campus.

\subsubsection{Estimated Costs of ATES with a Seasonal Chill Source}

The cost of energy supplied by an aquifer thermal energy storage (ATES) system from a seasonal chill source was investigated (Brown 1983). Costs were estimated for point demand and residential development ATES systems with the computer code AQUASTOR. In this analysis, the cost effect of varying a wide range of technical and economic parameters was examined. Those parameters exhibiting a substantial influence on the costs of ATES delivered chill were:

- system size

- well flow rate

- transmission distance

- source temperature

- well depth

- cost of capital.

The primary constraint of ATES chill systems is the extremely low energy density of the storage fluid. The energy available for chilling in a pound of $35^{\circ} \mathrm{F}$ water is approximately $208 \mathrm{tu}$, depending on the specific design characteristics of the system. By comparison, the energy available for heating in a pound of $325^{\circ} \mathrm{F}$ water is approximately 100 8tu, again depending on design conditions. Because of this much lower energy density, equipment for handling the chilled water must be substantially larger to deliver the same amount of energy. This relationship puts a premium on factors affecting wellfield and transmission system design. The cost effects of the parameters identified above are summarized below.

Significant economies-of-scale are available for ATES systems. In fact, fairly large systems are required to approach cost-effectiveness. 
Costs are fairly constant for peak demands (at 25\% 1oad factor) 8 to 10 MW and larger. Costs rise quickly for systems with peak demands of less than $5 \mathrm{MW}$. These trends appear to hold regardless of source temperature or system type (point demand or residential district).

Well flow rate has a substantial impact on ATES chili costs. Because of the low energy density of cold water, large amounts of water must be stored in the aquifer. Wellfields can be a substantial portion of ATES chill system capital costs. An increase in well productivity (flow rate) reduces the number of wells and pumps required. Fewer wells mean less interconnecting well manifolding and less pumping energy within the manifolds.

Lengthy transmission distances can quickly result in prohibitive costs, especially for smaller (less than $10 \mathrm{MW}$ ) ATES systems. Extensive transmission systems can become a major portion of system capital cost as well as increasing the thermal loss to surroundings. Larger ATES systems are somewhat shielded from these cost effects by economies-ofscale available in piping systems and a decrease in thermal loss to the surroundings per pound of water transported.

The source temperature deliverable to an ATES system is an important determinant of system economics. A lower source temperature ultimately allows a lower deliverable temperature to the user, with more usable energy per pound of water. This higher energy density allows lower system fluid flow and directly reduces the amount of piping, pumping, and well drilling required. The load reject temperature influences costs in a similar manner. An increase in load reject temperature essentially increases the amount of delivered energy at no increase in cost. The important overall factor, then, is the difference between the maximum usable (reject) temperature and the source temperature.

Well depth can be an important factor in ATES chill system costs. Increasing well depth increases the capital cost of the well and its purnp. Electrical energy required to pump water to the surface is also increased. Because the low energy density of chilled water necessitates 
the transportation and storage of large quantities of water, the cost effect of well depth is more pronounced than for hot water storage systems. Electrical pumping energy is a significant part of the delivered cost of chill; well pumping is a major portion of the electrical consumption.

Aquifer thermal energy storage systems for chilled water are also capital-intensive. As in warm water systems, the cost of financing is important in determining cost-effectiveness. Muncipalities obtain financing at lower interest than is available to private groups. Therefore, a municipality can consider a broader range of system parameters as potentially cost-effective.

The availability of a suitable aquifer is obviously of prime concern when considering an ATES installation. Potential site-specific availability of aquifers was not addressed. The analysis assumed a suitable aquifer existed and examined the cost effect of a range of possible thermal efficiencies. Aquifer thermal efficiency is an important ATES cost parameter, but no more so than the other parameters noted above.

The cost of ATES-delivered chill for a 5 -MW system with a $1.67^{\circ} \mathrm{C}$ $\left(35^{\circ} \mathrm{F}\right)$ source temperature was estimated to be $\$ 22.80 /$ MBtu. The comparable cost of chilled water from a compressive chiller device would be $\$ 8.96 / \mathrm{MBtu}$. Both levelized energy costs were calculated based on an electrical energy cost of $5 \$ / \mathrm{kWh}$ with $1 \%$ real escalation per year. Compared with ATES-delivered heat, ATES-delivered chill suffers from two major disadvantages when competing with conventional energy systems. First, the low energy density of the cold water requires an expensive investment to deliver a relatively small amount of energy. Second, the competing technology, electrically driven compressive chillers, is highly efficient. Therefore, cost-effective ATES chill systems will be limited to special situations with design conditions more advantageous than those considered here.

Of the cost components for a 5-MW point demand system with a $1.67^{\circ} \mathrm{C}$ $\left(35^{\circ} \mathrm{F}\right)$ source temperature, capital costs dominate. However, operating 
and maintenance and electricity charges are significant portions of the total levelized energy cost. Electricity charges are more important for ATES chill systems than for ATES heat systems because purchased thermal energy costs and the pumping of large quantities of water are absent. As system size increases, the proportion of levelized energy cost attributable to electricity increases because capital equipment shows economies-of-scale, while pumping energy is directly proportional to water flow rate (system size).

\subsubsection{Aquifer Storage of Chilled Water at Stony Brook, New York}

Comprehensive cost estimates were made for chill aquifer thermal energy storage alternatives on the Stony Brook campus (Kannberg et al. 1982). Two options for developing thermal energy storage chill systems were evaluated:

- A small-scale demonstration on one or a few bujldings, which would use a small cooling tower and the existing aquifer doublet field.

- A full-scale demonstration of the original concept with the Marley cooling tower and the complete campus distribution system.

The approach used in preparing these conceptual designs was to first define the seasonal recovery efficiency for various temperature differentials (injection temperature versus recovery temperature, based upon the results of the already completed test program). The second step was to evaluate user needs, based upon the operating characteristics of the existing system, the practical minimum temperature to which water could be chilled in a cooling tower, and the necessary quantity of chilled water for injection to provide sufficient recovery at a usable temperature. Then, based upon the required storage volume and recovery efficiency, an aquifer storage system was designed. All equipment, material, and construction costs were calculated from Fall 1981 prices and New York area contracting costs. Operating costs for the conceptual ATES systems were then compared with current operating costs, and savings were divided into the ATES capital costs to provide simple payback period estimates. 
Application of ATES for air conditioning of the Stony Brook West Campus is technically feasibie. Although some difficulty was experienced with injection, it does not appear to be outside the scope of an engineering solution.

Results of the doublet test performed during the feasibility study indicate that the most significant parameter affecting storage efficiency is drift of the stored chilled water caused by natura] groundwater flow. Because of energy transfer from pore-fluid (groundwater) to formation medium (sand), thermal drift is reduced to approximately one-half the groundwater drift. Final design of the well field based upon the computer simulation of "best performance well position" would also provide for normalization of hydraulic gradient to minimize thermal drift and thereby maximize efficiency. Generally, it appears reasonable to expect recovery efficiencies of more than $80 \%$ for the full-scale demonstration option and $50 \%$ for the small-scale demonstration option. Because of capital cost weightings economic analyses indicated the following simple payback periods:

- smalt-scale demonstration -7.7 years

- full-scale demonstration - 11 to 12 years.

\subsection{ALTERNATIVE STORAGE CONCEPTS FOR CHILLED WATER}

Six seasonal ice generation and storage concepts were evaluated at the conceptual design level. The analysis included both technical and economic assessment of the concepts with a specific cost comparison to conventional air conditioning systems (Brown, Blahnik, and Huber 1982).

The six concepts selected for comparison with conventional air conditioning were:

- frozen earth with horizontal tube heat exchanger (HX)

- ice pond with horizontal tube $H X$

- ice tank with vertical tube $H X$

- ice tank with heat pipe $H X$

- incrementally filled ice pond

- artificial snow pond. 
The first three concepts use an outdoor fan coil to produce the ice in the store. The next concept uses a heat pipe. The incrementally filled ice pond uses direct chill by ambient winter air to freeze water as it is gradually added to the store. The last concept employs a snow-making machine to add ice to a pond.

The procedural steps of the concept analysis were 1) establish design assumptions and criteria, 2) select the simplest concepts from past development work, 3) size the store and equipment, 4) select materials for construction, 5) briefly evaluate the structural considerations, and 6) briefly evaluate the technical/economic tradeoffs. Conceptual designs were developed in an iterative process based upon what was learned during these analytical steps. Among the design/cost tradeoffs considered were insulation material and thickness, piping material and configuration, heat exchanger flow rates, tubing spacing, and approach temperatures.

The final conceptual designs were the basis for estimating capital and annual operating and maintenance costs for comparison with conventional air conditioning. These costs served as inputs for the calculation of life-cycle costs, levelized energy costs, and simple payback periods. The economic analysis indicated clearly that two concepts, the incrementally filled ice pond and artificial snow pond, would be competitive with conventional air conditioning. When life-cycle costs were compared, the remaining four concepts did not appear to be competitive.

Both initial capital investment and annual operating and maintenance costs were estimated for each concept based on its respective designs. The present worth of each concept was then calculated based on these capital and operating and maintenance estimates. The goal of the economic analysis was to provide cost data that are reasonably accurate and allow for equitable comparisons among the concepts.

Capital costs were estimated based on the individual design requirements for each concept. These estimates represent an aggregation 
of many individual component costs, including charges for contingency, indirects, and land. Land costs were included because of the 1 andintensive nature of the ice storage systems compared to conventional air conditioning systems. Because land costs are extremely site-specific, capital costs and other economic figures of merit are presented both with and without land costs. Table 7 presents capital cost estimates for the six ice storage concepts and a conventional air conditioning system.

TABLE 7. Capital Cost of Ice Storage and Conventional Air Conditioning Systems

\section{Concept}

Frozen earth

Ice pond with $H X$

Ice tank with $\mathrm{HX}$

Ice tank with heat pipe

Incrementally filled ice pond

Artificial snow pond

Conventional air conditioning

Costs in 1000s of Mid-T981 Dollars

With Land

657

475

584

577

205

219

70
Without Land

595

433

563

554

163

179

70

Annual operating and maintenance costs were disaggregated into operations labor, maintenance supplies and labor, antifreeze (material only; labor for changing antifreeze included in operations), and electricity for pumping. Minimizing annual operating and maintenance costs of ice storage systems is essential for them to be competitive with conventional air conditioning systems. Ice storage systems are quite capital-intensive compared to conventional air conditioning systems and must "repay" the incremental investment with annual savings in operating and maintenance costs. Annual operating and maintenance costs are listed by category in Table 8 . 
TABLE 8. Annual Operating and Maintenance costs Cost in 1000s of Mid-1981 Dollars

\begin{tabular}{|c|c|c|c|c|c|c|c|}
\hline Activity & $\begin{array}{c}\text { Air } \\
\text { Conditioning } \\
\end{array}$ & Earth & $\begin{array}{l}\text { Ice } \\
\text { Pond } \\
\mathrm{w} / \mathrm{HX}\end{array}$ & $\begin{array}{l}\text { Ice } \\
\text { Tank } \\
\text { W/HX }\end{array}$ & $\begin{array}{l}\text { Heat } \\
\text { Pipe } \\
\text { Tank }\end{array}$ & $\begin{array}{c}\text { Incrementally } \\
\text { Filled } \\
\text { Ice Pond } \\
\end{array}$ & $\begin{array}{l}\text { Snow } \\
\text { Pond }\end{array}$ \\
\hline Operations & 0.6 & 3.3 & 3.3 & 3.3 & 1.9 & 2.7 & 4.1 \\
\hline Maintenance & 1.1 & 7.0 & 5.5 & 8.0 & 7.9 & 2.4 & 2.7 \\
\hline Antifreeze & 0.0 & 1.2 & 2.4 & 1.7 & 0.0 & 0.0 & 0.0 \\
\hline Power & 18.0 & 2.0 & 2.5 & $2 . \underline{5}$ & $\underline{0.2}$ & $\underline{0.2}$ & $\underline{0.6}$ \\
\hline Total & 19.7 & 13.5 & 13.7 & 15.5 & 10.0 & 5.3 & 7.4 \\
\hline
\end{tabular}

Each concept was subjected to a life-cycle (present worth) cost analysis based on the estimates for initial capital investment and annual operating and maintenance expenses. Economic assumptions chosen for the analysis are intended to represent the financial situation for a potential ice storage system end user. Values of economic parameters used in the analysis are given in Table 9. Present worth estimates for ice storage and conventional air conditioning systems are presented in Tab]e 10.

TABLE 9. Economic Parameters for Present worth Anaiysis

\begin{tabular}{lc}
\multicolumn{1}{c}{ Parameter } & Value \\
\cline { 2 - 2 } Investment tax credit & $10 \%$ \\
Debt to equity ratio & $50 / 50$ \\
Salvage value & 0 \\
Oebt rate & $10 \%$ \\
Discount rate (before tax) & $16 \%$ \\
Effective income tax rate & $50 \%$ \\
General inflation rate & $6 \%$ \\
Energy escalation rate & $8 \%$ \\
Operation and maintenance & \\
escalation rate & $6 \%$ \\
System life (years) & 20 \\
Price year & 1981 \\
Year of operation & 1985
\end{tabular}


TABLE 10. Present worth of Ice Storage and Conventional Air Conditioning Systems

Present Worth

Concept

Frozen earth

\begin{tabular}{cc}
$\frac{\text { (Costs in 1000s of Mid-1981 Dol lars) }}{\text { With Land }}$ & Without Land \\
\hline 450 & 394 \\
346 & 308 \\
421 & 401 \\
386 & 364 \\
178 & 140 \\
159 & 120 \\
155 & 155
\end{tabular}

Ice pond with $\mathrm{HX}$

Ice tank with $\mathrm{HX}$

Ice tank with heat pipe

Artificial snow pond

Incrementally filled ice pond

Conventional air conditioning

155

155

Both the incrementally filled ice pond and the artificial snow pond appear to be strong competitors with conventional air conditioning technology. These two concepts offer comparably low delivered energy costs and a minimum of potential technical difficulties.

Based upon information obtained during the iterative conceptual design phase, a comparative technical assessment was also made. The technical assessment of the six concepts also indicated that the incrementaliy filled ice pond and artificial snow pond are superior because of their simplicity. Considerable development work is required for the other four concepts. 


\subsection{GENERAL CONCLUSIONS}

Seasonal thermal energy storage refers to the cyclic process by which energy is generated, saved, and then expended to reduce the effective cost. "Seasonal" may or may not be coupled with natura? climatic changes. Motivations for storing large quantities of thermial energy on a long-term basis include the need to store solar heat collected in summer for use in winter; the cost-effectiveness of storing heat that is now rejected from electrical generation plants; the need to profitably use industrial waste heat; and the need to reduce the cost of summer air conditioning.

The potential energy sources for seasonal thermal energy storage consist of solar heat, process heat, cogenerated heat, and climatic chill. Heat would be stored as hot water, possibly superheated, whereas chill would be stored as either chilled water or ice.

The potential markets for STES include space temperature conditioning for individual homes, districts, institutions, or industrial plants and process heat for manufacturing. Aquifers, lakes, ponds, quarries, caverns, mines, earth and rock, and engineered structures have potential for seasonal storage.

This variety of potential storage alternatives and applications has contributed to the extensive long-term international interest in and attention to developing STES. For example, China, which started using aquifers in the 1950 s to control subsidence in the Shanghai area, now uses this control strategy to supply store winter chill for summer air conditioning. Various projects in Switzerland, Denmark, and France have also contributed significantly to developing and verifying aquifer storage technology. In Canada, STES research and development has concentrated on thermal storage in tanks and as ice in addition to aquifer storage. Researchers in the Federal Republic of Germany are investigating the use of insulated artificial lakes and artificial aquifers; a pilot plant scale study of thermochemical storage of low-temperature heat is also underway. The most highiy developed heat storage technologies in Sweden are the water-filled insulated steel 
tank, the water-filled rock cavern, and the multiple well system in solid rock. In sum, these international R\&D efforts serve to underline the tremendous potential for STES, despite vast differences among the respective nations' geologic resources.

Aquifer thermal energy storage is the most feasible geologic storage technology for warm and chilled water in about $60 \%$ of the conteminous United States. Energy recovery efficiencies may exceed $70 \%$.

Aquifer thermal energy storage requires five conditions: 1) an available source of thermal energy or chill, 2) a technically feasible aquifer reservoir, 3) a market for the recovered energy or chi11, 4) compatibility between energy storage and utilization, and 5) economic competitiveness with alternative energy supplies.

The features of aquifers that coincide with STES design requirements include 1) large accessible volumes, 2) low thermal conductivities of containing rocks, 3) nigh enough permeability to allow injection and withdrawal of water, 4) low regional groundwater flow rate, and 5) proximity to energy supply and consumption points.

Mechanisms of aquifer system impairment include particulate plugging, chemical preciptiation, liquid-solid reactions (clay minera] dispersion and corrosion), formation disaggregation, oxidation reactions, and proliferation of biota. Beneficiation procedures are available to counter or minimize the effect of each potential event. For example, well development by bore reaming and gravel packing may preserve the permeability of the "sandface" region.

Numerical modeling enables prediction of the transport and retrieval of thermal energy resources within the groundwater environment. The Mobile, Alabama, field test illustrates the need to control subsurface heat losses in aquifers that are highiy permeable in the fluid storage region. High vertical permeability contributes to natural convective heat loss, whereas high horizontal permeability causes conductive heat loss to the reservoir boundary. 
The St. Paul, Minnesota, field test has proved that calcium carbonate and calcium magnesium carbonate precipitation at elevated temperatures can be controlled by incorporating a precipitator/filter system. The test has so far not demonstrated that loss of heat caused by warm buoyancy flow can be minimized in an aquifer with restricted vertical permeability.

A 50-MWt aquifer storage facility will probably require about 150 acres of land for subsurface storage. Legal, institutional, and regulatory factors will be worked out concomitantly with the growth of this technology.

The water-resources regions with most promise for near-term development have extensive aquifers, adequate water supplies, available energy sources, and proximate markets for direct use of warm or chilled water. In the U.S., these regions are: 1) mid-Atlantic, 2) South-Atlantic Gulf, 3) Ohio, 4) Upper Mississippi, 5) Lower Mississippi, 6) Souris-Red-Rainy (North Dakota), 7) Missouri Basin, 8) Arkansas-White-Red, 9) Texas-Gulf, and 10) California. Aquifer thermal energy storage may also be feasible in other regions. For any locale, site-specific investigations of geology, hydrology, and energy economy will be needed.

Detailed analyses of aquifer behavior with respect to deliverability, acceptability, regional groundwater flow, energy retention, geochemical reactivity, subsidence, and isolation from potable water reservoirs must be designed and conducted to satisfy feasibility and institutional requirements.

Nonaquifer STES systems would be required if aquifers were geologically unavailable, technically infeasible, or not acquirable. These aiternative systems include pond, lake, cavern, tank, wet earth, rock, and engineered surface or near-surface structure (for ice). Three favored heat storage technologies in Sweden are the water-filled insulated steel tank, the water-filled rock cavern, and the multiple well system in solid rock or unconsolidated soil. 
The most promising alternative STES concepts use temperatures below $95^{\circ} \mathrm{C}$, low-cost storage media (water and rock), construction with earth, good insulation, impervious liners, and economies of large scale.

Latent heat concepts (other than ice) and thermochemical concepts are relatively undeveloped and appear to be too high in cost for STES at this time.

In nonaquifer STES, economic analysis favors constructed storage for small to large capacities of ice, existing caverns for intermediate to large capacities of hot water, and lake storage for large capacities of warm water. Future implementation probably depends upon energy costs escalating more rapidly than general inflation.

Inventory turnover frequency significantly influences the economic justification for a storage system.

Use of heat pumps can enhance the economics through increased effective capacity, improved coefficient of performance, and flexibility in operations.

The economics of STES are infTuenced by cost of purchased energy, storage reservoir efficiency, capital cost, system size, source temperature, and transmission distance. 


\section{REFERENCES}

Allen, R.D. 1979. Thermal Energy Storage in Aquifers - Preliminary Information. PNL-3062, Pacific Northwest Laboratory, Richland, Washington.

Allen, R. D. and J. R. Raymond. 1982. "Progress in Seasonal Thermal Energy Storage." In Proceedings of Condensed Papers, 5 th Miami International Conference on ATternative Energy Sources, pp. 462-463. Clean Energy Research Institute, University of Miami, Coral Gables, Fiorida.

Andersson, S. and A. Eriksson. 1981. "Heat Storage in Rock - Multiple Well System." In Proceedings of International Conference on Seasonal Thermal Energy Storage and Compressed Air Energy Storage, Vo1. 1, pp. 255-262. CONF-811066, National Technical Information Service, Springfield, Virginia.

Blair, S.C. and J.A. Stottlemyre. 1981. "A New Laboratory Test Facility for Aquifer Materials." In Proceedings of International Conference on Seasonal Thermal Energy Storage and Compressed Air Energy Storage, Vol. T, pp. 263-269. CONF-811066, National Technical Information Service, Springfield, Virginia.

Blair, S. C. and W. J. Deutsch. 1983. "Determination of Important Physicochemical Processes at an Aquifer Thermal Energy Storage Site in Minnesota Using Both Laboratory and Field Techniques." In Proceedings of International Conference on Subsurface Heat Storage in Theory and Practice, Appendix, Part II, PP. 800-804. Swedish Council for Building Research, Stockholm, Sweden.

Blahnik, D.E. 1980. Prel iminary Survey and Evaluation of Nonaquifer Thermal Energy Storage Concepts for Seasonal Storage. PNL-3625, Pacific Northwest Laboratory, Richland, Washington.

Blahnik, D.E. 1981. "Preliminary Assessment of Promising Nonaquifer STES." In Proceedings of International Conference on Seasonal Thermal Energy Storage and Compressed Air Energy Storage, Vo1. 1, pp. 71-79. CONF-871066, National Technical Information Service, Springfield, Virginia.

Breger, D.S., A.E. McGarity and A.I. Michaels. 1983. "A Solar District Heating System Using Seasonal Storage for the Charlestown, Boston Navy Yard Redevelopment Project." In Proceedings of International Conference on Subsurface Heat Storage in. Theory and Practice, Appendix, Part II, pp, 417-422. Swedish Council for Building Research, Stockholm, Sweden.

Brown, D.R. 1983. Aquifer Thermal Energy Storage Costs with a Seasonal Chill Source. PNL-4567, Pacific Northwest Laboratory, Richland Washington. 
Brown, D.E., D.E. Biahnik and H.D. Huber. 1982. "Analysis and Assessment of STES Technologies." In Proceedings of the DOE Physical and Chemical Energy Storage Annual Contractors Review Meeting, pp. 147-146. CONF-820827, Nationa] Technical Information Service, Springfield, Virginia.

Drillers Journal, The Johnson. 1965. "Maintaining the Yield of Water Wells." January-February, PP. 1-4.

Friedrich, F.J. and V. Lottner. 1981. "Status of Research and Development Work for Long Term Thermal Energy in Germany." In Proceedings of International Conference on Seasonal Thermal Energy Storage and Compressed Air Energy Storage, Vol. 1, pp. 59-64. CONF-811066, National Technical Information Service, Springfield, Virginia.

Gallagher, B.J. T981. "Environmental and Institutional Considerations for Aquifer Energy Storage Projects; Seasonal Thermal Energy Storage and Compressed Air Energy Storage." In Proceedings of Internationa? Conference on Seasonal Thermal Energy Storage and Compressed Air Energy Storage, Vo?. 1, PP. 31-43. CONF-811066, National Technical Information Service, Springfield, Virginia.

Hagelskjaer, J., J. A. Leth and J. Mortensen. 1983. "Underground Heat Storage in Horsholm, Denmark." In Proceedings of International Conference on Subsurface Heat Storage in Theory and Practice, Appendix, Part I, pp. 232-241, Swedish Councif for Building Research, Stockholm, Sweden.

Huber, H.D., D.R. Brown and R.W. Reiliy. 1982. User Manual for AQUASTOR: A Computer Model for Cost Analys is of Aquifer Thermal Energy Storage Coupled with District Heating or Cooling Systems, Vols. I \& II. PNL-4236, Pacific Northwest Laboratory, Richland, Washington.

Hul tmark, 6. 1981. "Sunclay Broject - First Year Operation with a Seasonal Storage of $80,000 \mathrm{~m}^{3}$ Clay." In Proceedings of International Conference on Seasonal Thermal Energy Storage and Compressed Air Energy Storage, Vol. 1, pp. 172-176. CONF-811066, NationaT Technica? Information Service, Springfield, Virginia.

Intertechnology Corporation. 1977. Analysis of the Economic Potential of Solar Thermal Energy to Provide Industrial Process Heat, Vol. I. Warrentown, Virginia.

Iris, P. and J. P. Marie. 1983. "Overview of French Activity in the Field of Heat Storage in Aquifer." In Proceedings of InternationaI Conference on Subsurface Heat Storage in Theory and Practice, Appendix, Part I, pp. 242-245. Swedish Council for Building Research, Stockholm, Sweden. 
Kannberg, L. D., Staff Members and Subcontractors of Pacific Northwest Laboratory. 1982. Underground Energy Storage Program 1981 Annual

Report. PNL-4281, Vol. I \& II, Pacific Northwest Laboratory, Richland, Washington.

Kannberg, L. D., Staff Members and Subcontractors of Pacific Northwest Laboratory. 1983. Underground Energy Storage Program 1982 Annual Report. PNL-4735, Pacific Northwest Laboratory, Richland, Washington.

Karkheck, J., E. Powel1 and E. Beardsworth. 1977. "Prospects for District Heating in the United States." Science, Vol. 195, March.

Kreitlow, D.B. 1977. "Geothermal Well Downhole Heat Exchanger Design Analysis." M.S. Thesis, Oregon State University, Corvallis, Oregon.

Lindblom, U., A.B. Jacobson, W. Bogdanoff and I. 8ogdanoff. 1981. "The Blockfilled Cavern and Pond-New Systems for Low-Cost STES." In Proceedings of International Conference on Seasonal Thermal Energy Storage and Compressed Air Energy Storage, Vol. 1, pp. 302-309. CONF-811066, National Technical Information Service, Springfie?d, Virginia.

Lindbo, T., and T. Bruce. 1981. "Alternative Energy Storage for the Swedish IEA National Design CASE." In Proceedings of International Conference on Seasonal Thermal Energy Storage and Compressed Air Energy Storage, Vol. 1, pp. 67-69. CONF-811066, National Technical Information Service, Springfield, Virginia.

Martna, J. 1981. "The Avesta Test Plant for Storage of Hot Water in an Unl ined Rock Cavern." In Proceedings of International Conference on Seasonal Thermal Energy Storage and Compressed Air Energy Storage, vol. 1, pp. 186-193. CONF-811066, National Technical Information Service, Springfield, Virginia.

McCune, C.C. 1977. "On-Site Testing to Oefine Injection-Water Quality Requirements." Journal of Petroleum Technology. January, pp. 17-24.

Melville, J.G., F.J. Molz, A.D. Parr, D.A. King and M.T. Hopf. 198 ?. "Aquifer Storage Using Ooublet Well Configuration." In Proceedings of International Conference on Seasonal Thermal Energy Storage and Compressed Air Energy Storage, Vo T. 1, pp. 104-112. CONF-811066, National Technical Information Service, Springfield, Virginia.

Melville, J.G., F.J. Molz and 0. Guven. 1982. "Mobile Field Test Facility." In Proceedings of the DOE Physical and Chemical Energy Storage Annual Contractors' Review Meeting, pp. 116-125. CONF-820827, National Technical Information Service, Springfield, Virginia.

Mercer, J. W., C. R. Faust, W. J. Miller and F. J. Pearson, Jr. 1981. Review of Simulation Techniques for Aquifer Thermal Energy Storage (ATES). PNL-3769, Pacific Northwest Laboratory, Richland, washington. 
Meyer, C.F., W. Hausz, B.L. Ayres and H.M. Ingram, 1977. Role of the Heat Storage well in Future U.S. Energy Systems. GE7 $\overline{6 T M P}-27 \mathrm{~A}$, GE Tempo, Santa Barbara, California.

Meyer, C. F., and W. Hausz. 1980. Guidelines for Conceptual Design and Evaluation of Aquifer Thermal Energy Storage Systems, GE80TMP-44, Final Report, TEMP0, Genera] E]ectric Company, Santa Barbara, California.

Molz, F.J., A.D. Parr and P.F. Andersen. 1979. "Thermal Energy Storage in Aquifers: Experimenta] Study." In Proceedings of the 14 th Intersociety Energy Conversion Engineering Conference, Vol. I, PP. 534-537. American Chemical Socjety, Washington, D. C.

Morofsky, E. L. 1983. "Overview of Canadian Aquifer Thermal Energy Storage Field Trials." In Proceedings of International Conference on Subsurface Heat Storage in Theory and Practice, Appendix, Part I, pp. 227-23T. Swedish Council for Building Research, Stockholm, Sweden.

01sen, H., and J. Reffstrup. 1983. "Lnderground Storage in Horsholm, Denmark." In Proceedings of Internationa T Conference on Subsurface Heat Storage in Theory and Practice, Appendix, Part II, pp, 444-450. Swedish Council for Building Research, Stockholm, Sweden.

Platell, 0.B. 1981. "Sunstore - The Complete Solar Energy System for Heating." In Proceedings of International Conference on Seasonal Thermal Energy Storage and Compressed Air Energy Storage, VoT. 1, pp. 178-185. CONF-811066, National Technical Information Service, Springfield, Virginia.

Prater, L. S., J. R. Eliason and V. E. Hampel. 1981. "The Seasonal Thermal Energy Storage Technology Information System." PNL-SA-8800, Pacific Northwest Laboratory, Richland, Washington.

Raymond, J. R. 1980. "Geohydrologic Aspects of Aquifer Therma? Eneray Storage." PNL-SA-8834, Pacific Northwest Laboratory, Richland, washington.

Reilly, R.W., D.R. Brown and H.D. Huber. 1981a. Aquifer Thermal Energy Storage Costs with a Seasonal Heat Source. PNL $-\overline{4135}$, Pacific Northwest Laboratory, Richiand, Washington.

Reilly, R. W., D. R. Brown ahd H. D. Huber. 1981b. "The Cost of Heat Storage from a Seasonal Source." In Proceedings of International Conference on Seasonal Thermal Energy Storage and Compressed Air Energy Storage, Vol. T, pp. 429-439. CDNF-811066, Nationai Technical Information Service, Springfield, Virginia.

Saugy, B., et al. 1983. "First Results of a Large Scale Underground Heat Storage Plant." In Proceedings of International Conference on Subsurface Heat Storage in Theory and Practice, Appendix, Part I, pp. 253-266. Swedish Council for Building Research, Stockholm, Sweden. 
Schaetzle, W.J., C.E. Brett, G.A. Jackins, Jr. and E.B. Miller. 1981. "Free-Cooling Applications Using Annual Aquifer Thermal Energy Storage." In Proceedings of International Conference on Seasonal Thermal Energy Storage and Compressed Air Energy Storage, Vol. 1, pp. 311-319. CoNf-811066, National Technical Information Service, Springfield, Virginia.

Skinner, W.V. and D.J. Supkow. 1982. "Conceptual Design of Aquifer Thermal Energy Storage System Demonstration - State University of New York, Stony Brook Campus, Long Is land." In Proceedings of the Mechanical, Magnetic and Underground Energy Storage 1987 Annual Contractors Review, PP. 110-118. CONF-810833, National Technical Information Service, Springfield, Virginia.

Supkow, D. J. and W. V. Skinner. 1981. "Characterization and Modeling of an Unconsolidated Aquifer for 40,000 MWH of Chill Storage at Stony Brook." In Proceedings of International Conference on Seasonal Thermal Energy Storage and Compressed Air Energy Storage, Vo1. 1, pp. 218-243. CoNF-811066, National Technical Information Service, Springfield, Virginia.

Svedinger, B. 1981. "Actual Applications of Low Temperature Storage Systems in Sweden." In Proceedings of International Conference on Seasona] Thermal Energy Storage and Compressed Air Energy Storage, Vol. T, PP. 53-57. CoNF-811066, National Technical Information Service, Springfield, Virginia.

Tsang, C.F., T.A. Buscheck and C. Doughty. 198la. "Aquifer Thermal Energy Storage--A Numerical Simulation of Auburn University Field Experiments." Water Resources Research, Vo1. 17, Pp. 647-658.

Tsang, C.F., T.A. Buscheck, and C. Doughty. 1981b. "Aquifer Thermal Energy Storage--Recent Parameter and Site-Specific Studies." In Proceedings of International Conference of Seasonal Thermal Energy Storage and Compressed Air Energy Storage, Vo1. 1, pp. 132-140. CONF-811066, National Technical Information Service, Springfieid, Virginia.

U.S. Department of Energy. 1981. Environmenta] Assessment. Aquifer Thermal Energy Storage Program. DOE/EA-0131, U.S. Department of Energy, Washington, D.C.

Vetter, 0.J. and D.A. Campbel1. 1979. "Carbonate Scale Inhibition in Republic's East Mesa Geothermal Operations." Geothermal Resources Council Transactions, Vo1. 3, pp. 757-760. Geotherma1 Resources Council, Davis, California. 
Walton, M.S. 1981. "The Aquifer Thermal Energy Storage (ATES) Program-University of Minnesota." In Proceedings of International Conference on Seasonal Thermal Energy Storage and Compressed Air Energy Storage, Vo1. 1, pp. 132-140. CONF-811066, National Technical Information Service, Springfield, Virginia.

Walton, M.S. and M.C. Hoyer. 1982. "University of Minnesota Aquifer Thermal Energy Storage Field Test Facility." In Proceedings of the Department of Energy Physical and Chemical Energy Storage Annual Contractors' Review Meeting, pp. 111-115. CONF-820827, National Technical Information Service, Springfield, Virginia.

Wijsman, A.J.Th.M. 1981. "A Group of Solar Houses with Seasonal Heat Storage in the Soil." In Proceedings of International Conference on Seasonal Thermal Energy Storage and Compressed Air Energy Storage, Vol. 1, p. 281. CONF-817066, National Technical Information Service, Springfield, Virginia.

Yan, Qi-Sen. 1981. "The Development and Application of Aquifer Storage in China." In Proceedings of International Conference on Seasona? Therma ] Energy Storage and Compressed Air Energy Storage, Vol. I, Pp. 142-149. CONF-817066, National Technical Information Service, Springfield, Virginia. 


\section{DISTRIBUTION}

No of

Copies

OFFSITE

US Department of Energy

Attn: U. Brogan

Office of Energy Systems Res.

Forrestal BIdg, CE-141 5E-D52

Washington, DC 20585

US Department of Energy

Attn: I. Gyuk

Office of Energy Systems Res.

Forrestal B1dg, CE-141 5E-052

Washington, DC 20585

US Department of Energy

Attn: R. Shivers

Office of Energy Systems Res.

Forrestal B1dg, CE-141 5E-052

Washington, DC 20585

US Department of Energy

Attn: Director, Policy and

Planning

Office of Conservation and

Solar Applications

Washington, DC 20545

27 DOE Technical Information Center

Argonne National Laboratory

Solar Thermal Storage Program

Attn: A. Michaels

Building 362

9700 S. Cass Avenue

Argonne, IL 60439

Auburn University

Attn: F. J. Molz

School of Engineering

Auburn, AL 36830
No of

Copies

Colorado School of Mines

Attn: Donald Langmuir

Dept. of Chemistry and Geochemistry

Golden, C0 80401

GeoTrans Inc.

Attn: J. W. Mercer

PD Box 2550

Reston, VA 22090

Wa 1 ter Hausz

4520 Via Vistosa

Santa Barbara, CA 93170

Lawrence Berkeley Laboratory

Attn: C. F. Tsang

University of California

Bldg. 90, Room 1012-H

1 Cyclotron Road

Berkeley, CA 94720

Lawrence Livermore Laboratory

Attn: Tech. Info. Dept, L-3

University of California

P0 Box 808

Livermore, CA 94550

Charles F. Meyer

1141 Cima Linda Lane

Santa Barbara, CA 93108

Minnesota Geological Survey

Attn: M. Walton

319 15th Avenue S.E.

Minneapolis, MN 55455

National Science Foundation

Division of Advanced Energy

Research and Technology

Room 1140

1800 G Street, Ni!

Washington, DC 20550 
No of

Copies

New York State Energy

Research \& Development Agency

Attn: Director

Rockefeller PTaza

Albany, NY 12223

New York State Energy

Research \& DeveTopment

Agency

Attn: Gunnar Walmet

Rockefeller Plaza

Albany, NY 12223

Oak Ridge National Laboratory

Attn: J. F. Martin

PO BoX Y

Oak Ridge, TN 37830

Office of Congressman

Sid Morrison

Attn: Kevin Billings, Legislative Asst.

1330 Longworth Bldg.

Washington, DC 20515

Rocket Research

Attn: L. B, Katter

York Center

Redmond, WA 98052

Sandia Laboratories

Attn: L. Radosevich

PO Box 969

Livermore, CA 94550

Sandia Laboratories

Technical Library Div. 3741

Albuquerque, NM 87185

Solar Energy Research Inst.

Attn: Director

1536 Cole BIvd.

Golden, CO 80401
No of

Copies

Tennessee Valley Authority

Attn: William Waldrop

Asst. Branch Chief

Water Systems Develop. Branch

Division of Water Management

PO Drawer E

Norris, TN 37828

Terra Tek, Inc.

Attn: C. Cooley

University Research Park

400 Wakara Way

Sait Lake City, UT 84108

TRW Energy Systems Group

Attn: E. Berman

Technical Library

7600 Colshire Orive

McLean, VA 2210 ?

Union Carbide Corporation

Nuclear Division

Attn: Library

$\mathrm{Y}-12$ Plant

PO Box Y

Oak Ridge, TN 37830

University of Minnesota

Attn: W. E. Soderberg

Program Director, ATES

Physical Plant Operations

200 Shops Bidg.

319 15th Avenue S.E.

Minneapolis, MN 55455

US Army Corps of Engineers

Attn: Library

P0 Box 59

Louisville, KY 40202

US Department of Interior

Attn: Natural Resources

Library

Serials Branch (G/E)

Washington, DC 20240 
No of

Copies

FOREIGN

Bengt Hidemark Gosta Danielson

Arkitekter SAR

Attn: A. Boysen

Jarntorget 78

S-11 29 Stockholm

Sweden

Public Works of Canada

Attn: E. L. Morofsky

C456 Sir Charles Tupper B1dg.

Riverside Dr. and Heron Rd.

Ottawa, Ontario

KIA OM2 Canada

ONSITE

DOE Richland Operations off.

H. E. Ransom/D. R. Segna

4n Pacific Northwest Laboratory

R. D. Allen (5)

S. C. Blair

L. D. Kannberg (25)

J. R. Raymond

L. Vajl

Technical Information (5)

Publishing Coordination (2) 
